\title{
How High-technology Female Entrepreneurs Perceive and Overcome Startup Challenges
}

\author{
By
}

Afaf Alzahrani

\begin{abstract}
A thesis submitted to the Faculty of Graduate and Postdoctoral Affairs in partial fulfillment of the requirements for the degree of

Masters of Applied Science

in
\end{abstract}

Technology Innovation Management

Carleton University

Ottawa, Ontario

(C) 2014, Afaf Alzahrani 


\begin{abstract}
This research investigates the problems and challenges facing high-technology female entrepreneurs in Canada. After an extensive literature review on entrepreneurial challenges and means to overcome them, five Ottawa-based women technology entrepreneurs were interviewed to find out how they perceive these challenges. The findings show that they considered the most important challenges as the lack of technologically innovative business ideas, the lack of sufficient business network, and the lack of business and management skills. The study contributes to the entrepreneurship literature by suggesting that these external challenges to female technology entrepreneurship are more essential than internal factors including family obligations, the lack of motivation, or the difficulty of overcoming previous bad experiences. The findings suggest that aspiring female technology entrepreneurs should partner with entrepreneurial support organizations such as 'Lead to Win for Women' and academic educational programs such as Carleton University's TIM program to get better technological ideas and business advice.
\end{abstract}




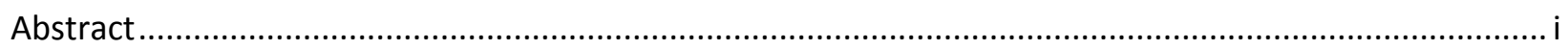

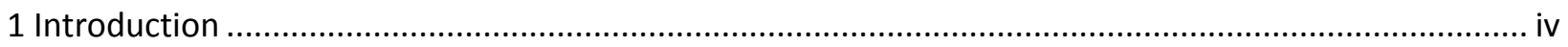

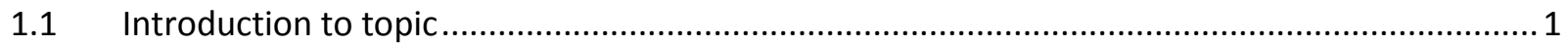

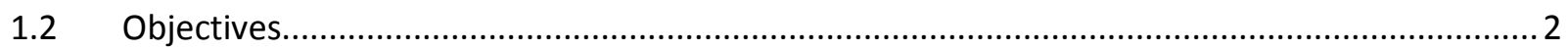

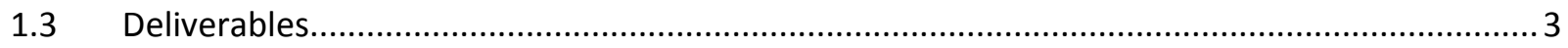

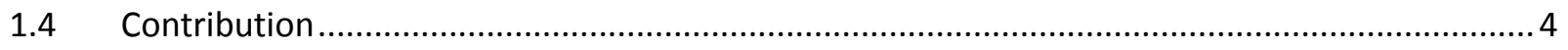

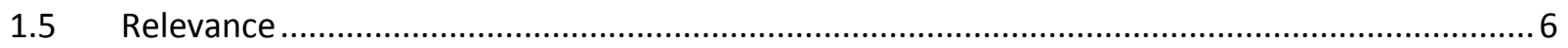

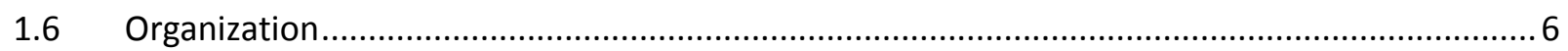

1.7 Identified Limitations in Prior Literature and the Research Gap .......................................... 7

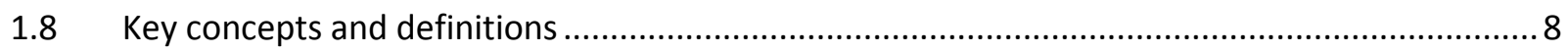

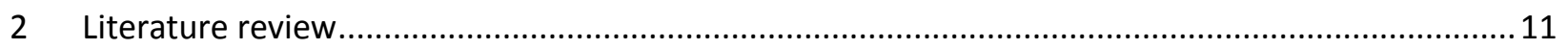

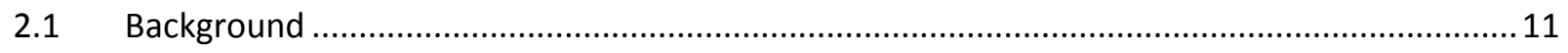

2.2 Importance of entrepreneurship and technology entrepreneurship .................................... 12

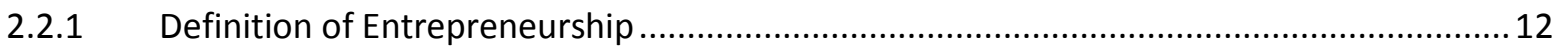

2.2.2 Definition of Technology Entrepreneurship (TE) ..................................................... 13

2.2.3 Difference between traditional entrepreneurs and technology entrepreneurs ................ 14

2.2.4 Women entrepreneurship in Canada .......................................................................... 14

2.3 Motivation and challenges of high-technology female entrepreneurs .................................. 18

2.3.1 Female Entrepreneurs' Motivations ...................................................................... 18

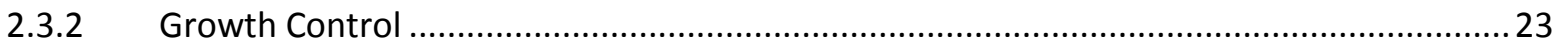

2.3.3 Challenges Faced by Female Entrepreneurs ........................................................... 24

2.3.4 Role of Ecosystems and Keystone Organizations …................................................ 49

2.4 Female Technology Entrepreneurs' Coping Strategies ....................................................5 52

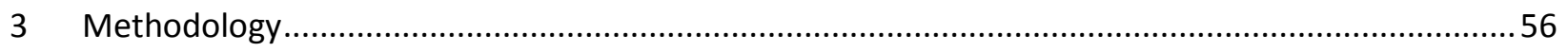

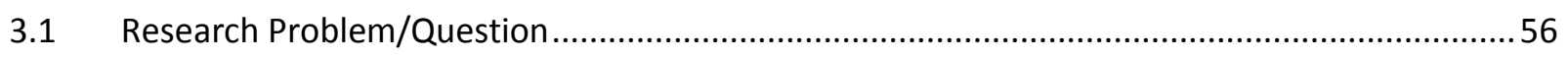




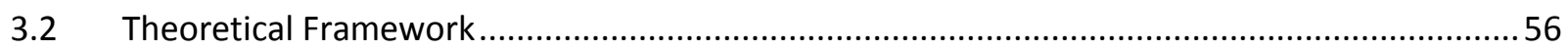

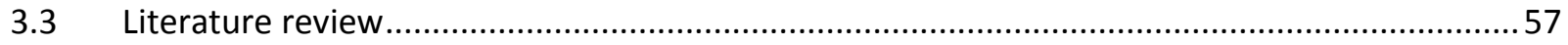

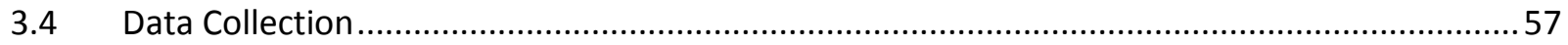

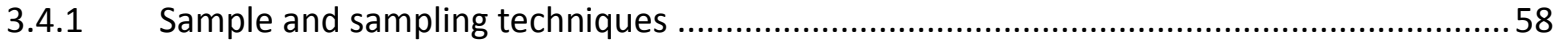

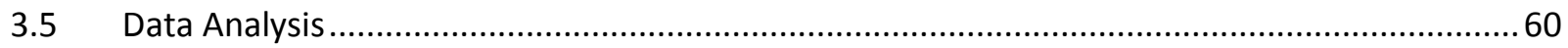

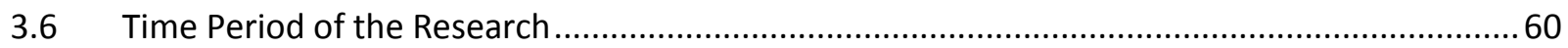

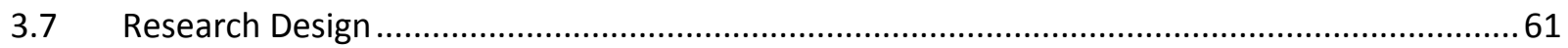

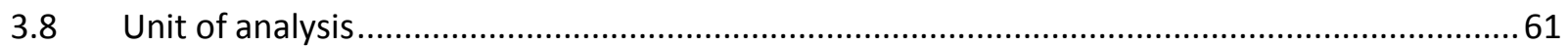

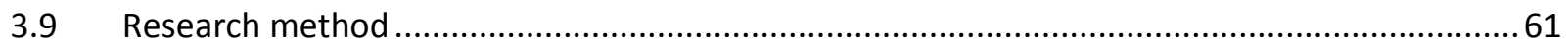

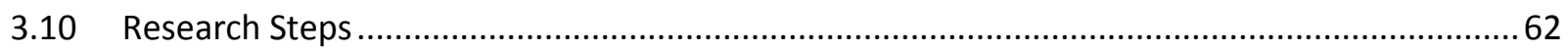

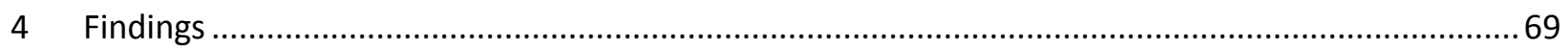

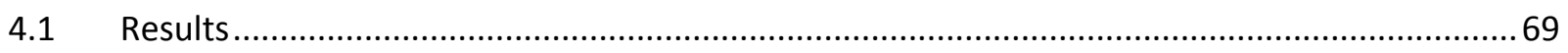

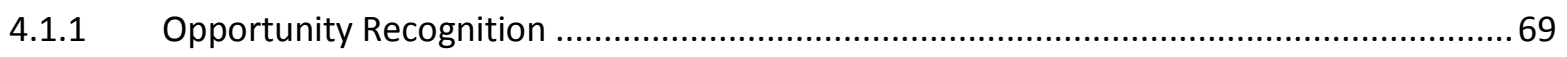

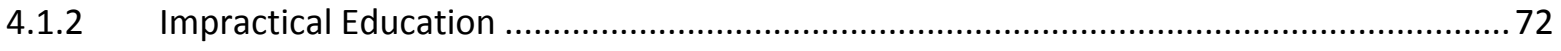

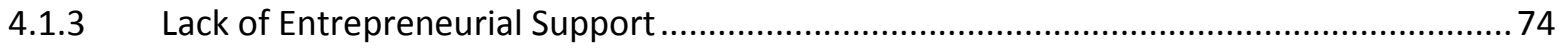

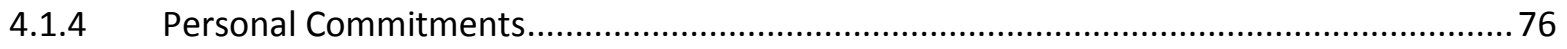

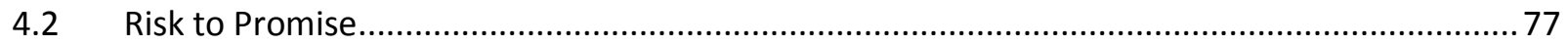

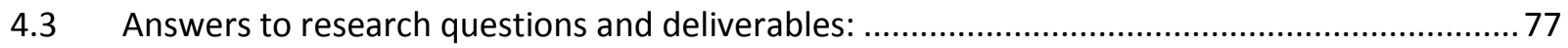

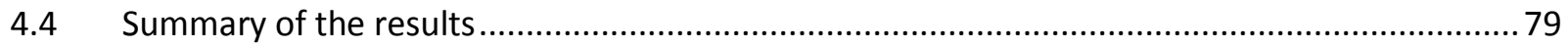

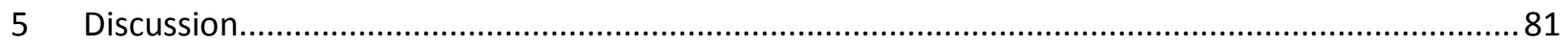

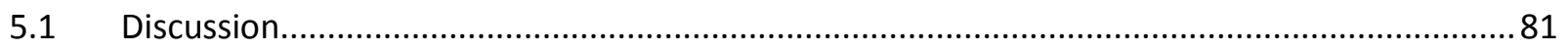

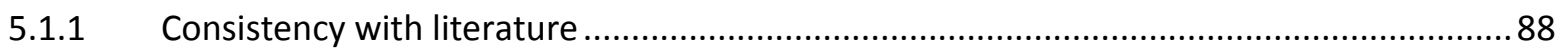

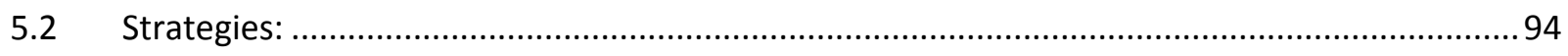

5.2.1 Female Entrepreneurs Strategies ….................................................................. 94

a) Partnership with Entrepreneurial Support Organizations .............................................. 94 
b) Partnerships with Educational Programs and Research Institution .................................. 95

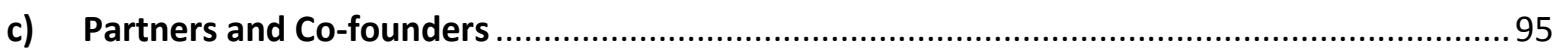

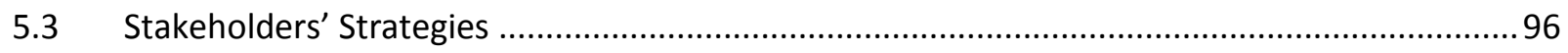

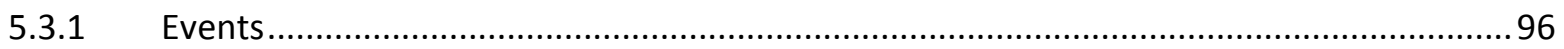

5.3.2 Annual High Technology Female Business Award .................................................... 97

5.3.3 Creation of Educational Programs and Research Institutions ........................................97

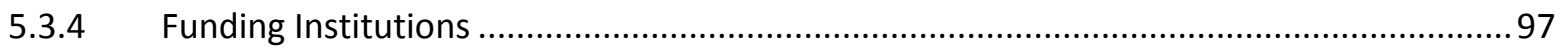

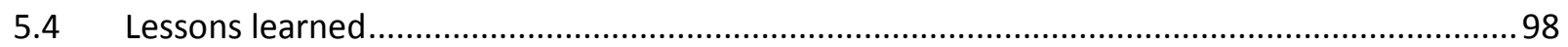

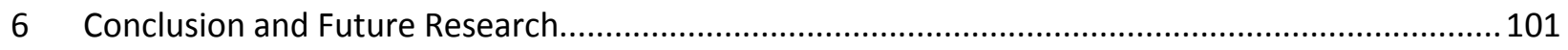

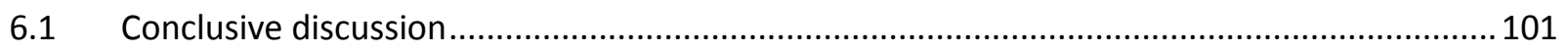

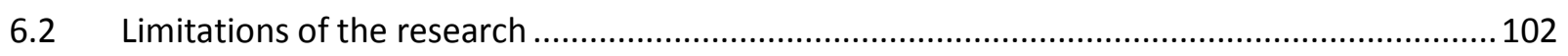

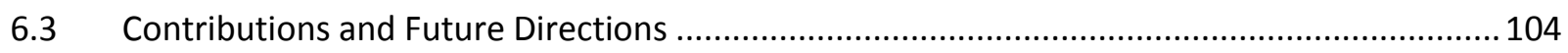




\section{Chapter 1: Introduction}

Chapter 1 is divided into seven sections. First part presents a brief introduction; the second part provides an overview of the research; the third section outlines the deliverables of the research; the fourth section provides contribution of the study, and sections five, six and seven consist of relevance, organization, and key definitions respectively.

\subsection{Introduction to topic}

The number of female entrepreneurs has grown in recent years. Their number in Canada increased by $40 \%$ compared to $38 \%$ increase in male entrepreneurs (Industry Canada, 2005; Government of Canada, 2012). However, only $7 \%$ of women entrepreneurs export their products to markets outside Canada compared to $13 \%$ of male entrepreneurs (Statistics Canada, 2001). Furthermore, in both the United States and Canada, women account for approximately half of the working population yet remain significantly under-represented in advanced technology and knowledge-intensive enterprises (Scarborough and Zimmerer, 2000; Orser, 2012). Male entrepreneurs own $86 \%$ of high technology sector's businesses, whereas the majority of female entrepreneurs operate start-ups in traditional businesses such as retail (Sigismund, 2000).

Although the number of women who own high technology businesses is rising, it seems that female entrepreneurs are discouraged to join a high-technology sector for various reasons. Women are mainly interested in start-up businesses in traditional sectors because they have job experience in those fields (Carter et al., 2003). Previous work experience helps women to build their confidence and business network necessary to start-up their own businesses (Scott, 2000). Moreover, it does not take an exclusive knowledge to start up a business or to stay in business in 
retail and traditional industries. Various studies, such as Entrepreneur magazine and PWC's 2006 Entrepreneurial Challenges Survey (http://www.entrepreneur.com/article/81812) show that compared with non-technology companies, creating a successful high-technology business requires specific technological and business knowledge, development of high-quality products to dynamic market needs, building of alliances for rapid international expansion, and the infusion of money through quality investors.

There is scarce research on the perception of entrepreneurial problems and challenges faced by high-technology female entrepreneurs, especially in Canada. There are also few studies discussing these perceptions in terms of their relative significance (cf. Siddiqui, 2008). Moreover, prior research is silent on the role of entrepreneurial support organizations and educational programs such as the Ottawa-based Lead-to-Win for Women and Carleton University's TIM program in helping women overcome these challenges. This research builds on a literature review and empirical research to investigate perceived problems and challenges faced by high-technology female entrepreneurs as well as the role of entrepreneurial support organizations and educational programs in strategies to overcome these challenges..

\subsection{Objectives}

The objective of this study is to explore the problems and challenges that hightechnology female entrepreneurs face and suggest possible solutions. These challenges have become entry barriers for female entrepreneurs (cf. Siddiqui, 2008). The study focuses on women entrepreneurs' perceptions of these challenges, their relative importance, and the ways they can be solved. The understanding of perceived problems and challenges enables the research to explore the role of entrepreneurial support organizations, educational programs and different coping strategies. Policy makers can use the findings of this study to implement policies 
and procedures to lower the entry barriers and minimize obstacles to the growth of women's technology businesses.

Moreover, the paper examines the role of organizations and academic institutions like 'Lead to Win for Women' and Carleton University's 'Technology Innovation Management' (TIM) program in helping the female entrepreneurs to overcome their problems. These educational organizations and academic programs were started to support high-technology entrepreneurs through a multitude of services, including expert advice from academic professors, consultants, and high-technology professionals. The TIM program provides education and support to high-technology managers and entrepreneurs during the different phases of their businesses. 'Lead to Win for Women' focuses on women and provides help to a range of issues faced by technology female entrepreneurs especially in the early phases of business.

\subsection{Deliverables}

The research provides various deliverables:

The literature review enables the researcher to collect previously identified problems and challenges facing female entrepreneurs, which establishes a clear image of the reasons of women's under-representation in the Canadian high-technology sector. The value of the literature review focused on entrepreneurial problems and challenges is that it gathers information from a large number of prior researches and vehicles them in one research which facilitates the mission of researchers, entrepreneurs, and decision makers in taking necessary steps to work out these challenges facing female high-technology entrepreneurs.

The division of these challenges gathers the entrepreneurial problems and challenges into clear categories that help to specify which actors can find and implement the necessary solutions. 
Entrepreneurs and stakeholders would be able to identify the right institution or individual they should approach to solve their problem. Also, these categories enable decision makers to establish entrepreneurial support programs and identify which institutions should be in charge of these programs.

The use of empirical study puts forward the problems and challenges facing women technology entrepreneurs by investigating the perceived importance of these challenges for them. Thus, this study increases the awareness among different economic agents in the economy about challenges faced by high-technology female entrepreneurs.

\subsection{Contribution}

The study is unique in different ways. There is a scarcity in research on high-technology female entrepreneurs, especially operating in Canada, and the problems and challenges they face during the early stages of operation. The research is divided into different successive steps. Previous research mainly approaches female entrepreneurs in general, not high-technology female entrepreneurs in particular, and studies a specific challenge such as financing or family obligation or a specific, usually patriarchal cultural context, in which female entrepreneurship is uncommon and female gender is seen strongly dependent on males (e.g., Siddiqui, 2008; Robinson, 2008; Mwobobia, 2012).

The first contribution of the research is that it reviews a large number of research papers and gathers various challenges faced by female entrepreneurs in order to present them within one study. The findings show that the main challenges facing female technology entrepreneurs in Canada are the lack of technological business idea, lack of business and management skills, lack 
of financial support, lack of sufficient business network, family obligations, lack of motivation, overcoming bad business experiences, and risk to promise.

The second contribution of the research resides in dividing these challenges into opportunity recognition challenges, impractical education challenges, personal commitment challenges, and entrepreneurial support network challenges.

The third contribution of the research is putting the challenges perceived by female entrepreneurs within the high-technology female entrepreneurs' context. The research uses interviews with five high technology female entrepreneurs to investigate the importance of these challenges for them. Based on the interviews; opportunity recognition, impractical education, and entrepreneurial support network challenges are more important for high technology female entrepreneurs than their personal commitments' challenges.

Finally, the study provides different strategies to help high-technology female entrepreneurs to launch, operate, and grow their companies and consequently decrease the underrepresentation of women in the high-technology sectors. The study suggests that female technology entrepreneurs should partner with entrepreneurial support organizations and academic educational programs and institutions. The study also recommends decision makers and stakeholders to help high-technology female entrepreneurs by organizing events, annual high-technology female business award events, creation of educational programs and research institutions, creation of funding institutions and organizations for women (e.g., F Capitals), and decrease the tax on capital gain on high-technology female entrepreneurs' project financing. 


\subsection{Relevance}

This research is relevant to different stakeholders. It helps the policy makers, education professionals, researchers, and high-technology female entrepreneurs.

First, this research is beneficial for policy makers; it enables them to diagnose the problems to implement new policies to lower the obstacles that high-technology female entrepreneurs face. The increase in the high-technology female entrepreneurs helps to increase the value added of the country, the job creation, and the technological solutions to different problems.

Second, the study is relevant for education practitioners because it gives them an idea about the educational programs that are required in the labor market. Using the study's findings, education professionals will be able to design new relevant programs to help increase the number of women entrepreneurs in the high-technology field.

Third, the thesis is relevant for researchers because it enriches the literature from a across literature review supported by a qualitative study. Many findings of this study call for further research to build the literature in this field especially that the literature on the high-technology female entrepreneurs is sparse.

Finally, female entrepreneurs will benefit from this study because it gives them strategies to overcome the perceived challenges. It also addresses the relevance of professional formal or informal organizations such as Lead-to-Win in helping them to overcome those challenges.

\subsection{Organization}

This study is divided into six chapters. Chapter one presents problem overview, the research's deliverables, contributions, as well as relevance and paper organization. Chapter two 
presents the background and the literature review. The third chapter discusses the methodology used to investigate the research issue. Chapter four presents the results of the research based on qualitative methods. Chapter five discusses the findings and their relevance with the literature. Finally, Chapter six concludes the paper, and provides its limitations and suggests possible future research avenues.

\subsection{Identified Limitations in Prior Literature and the Research Gap}

The extant literature on entrepreneurial barriers has its limitations. First, the academic articles that address high-technology female entrepreneurs' problems and challenges are sparse. Although some articles address various factors encouraging high-technology female entrepreneurs to start-up their own businesses, and the possibilities to solve women entrepreneurs' under-representation in technology sectors, these articles fail to provide a comprehensive list of challenges faced by female technology entrepreneurs and strategies that they can use to overcome these barriers.

Second, a limited number of scholarly articles provide relative importance on technology female entrepreneurship and the entrepreneurial challenges women face when starting their hightechnology businesses (Anna et al., 2000). Few studies, e.g., Siddiqui (2008) address the significance of perceived problems and challenges in terms of their relative importance, but lack the focus on technology entrepreneurship and/or examine more patriarchal cultural contexts. To date the literature has focused on issues of female entrepreneurs in retail/small businesses or entrepreneurs in high-technology in general. Thus, more efforts are required to acquire understanding on these phenomena, especially in the North American context. This study discusses and compares different obstacles and issues facing women in high-technology sector and the possible solutions. 
Although there is a good amount of literature discussing separate challenges faced by entrepreneurs, there is a shortage of papers addressing the challenges of the high-technology female entrepreneurs and the practical solutions to these challenges. First, this thesis differs from other studies since it gathers a number of high-technology female entrepreneurs' challenges from different papers and brings them in the same research. The literature review provides recommendations directed specifically to solve these challenges. Second, this thesis distinguishes itself by trying to understand the relative importance between these challenges for hightechnology female entrepreneurs in Canada.

\subsection{Key concepts and definitions}

Female Entrepreneurs: Women who organize and operate one or more businesses, taking financial risks in order to do so.

High-technology Female Entrepreneurs: Women acting and operating one or more businesses in high-technology sectors, taking on greater than normal financial risks.

Opportunity Recognition: A category that includes of the lack of technologically innovative business ideas and the lack of sufficient business network, which are key challenges of finding and recognizing business opportunities.

Entrepreneurial Challenge: The Oxford dictionary (http://www.oxforddictionaries.com/) defines a challenge as "a task or situation that tests someone's abilities". In academic literature on entrepreneurship, a challenge is a dilemma or a problem that the entrepreneur experiences. For example, Robinson (2008) discussed how entrepreneurs experience and deal with ethical dilemmas and Siddiqui (2008) investigated different problems and challenges facing women entrepreneurs, suggesting that these challenges are obstacles to female entrepreneurship. 
Capital Funding Institution: All governmental and non-governmental funding institutions including banks and investors who provide funds and loans for entrepreneurs.

Impractical Education: Practical education in business and management allow females to gain confident and recognise their management mistakes. Also, the impractical education prevents high technology entrepreneurs from developing their businesses because of the lack of business and management skills and lack of motivation.

Entrepreneurial Support: Includes all challenges facing high technology female entrepreneurs because of the lack of connections in the industry and stakeholders. This category includes the lack of financial support and overcoming bad business experiences.

Personal Commitments: This category includes family obligations and risk to promise. Family obligations represent the internal personal commitments such as taking care of children and household chores. Risk to promise includes the external commitments because making promises to pay back loans puts female entrepreneurs under pressure.

Lack of Technologically Innovative Business Ideas: The technological knowledge enables entrepreneurs to create innovative ideas that can be developed to business.

Lack of Business and Management skills: The lack of management and business education may cause the entrepreneurs to limit the growth of their companies and/or drive their business to bankruptcy.

Lack of Financial Support: All problems related to providing financial resources to start a company. This lack might be due to discrimination or other factors. 
Lack of Motivation: The lack of confidence in oneself because females think that they may not be successful or because they do not have the abilities to forecast and recognise the business opportunities.

Risk to Promise: Females are reluctant to put pressure on themselves by giving promises to financial institutions because they are not sure if the business will succeed or fail.

Family Obligations: all household chores and children commitments.

Decision Makers: government and authorities responsible of making decisions and laws to help female entrepreneurs. 


\section{Chapter 2: Literature review}

The chapter is organized into three sections. The first section provides definitions of entrepreneurship and technology entrepreneurship and distinguishes their characteristics. The second section describes motivational factors and challenges of women entrepreneurs in the high-technology sector. The third section discusses female technology entrepreneurs' coping strategies to overcome these challenges.

\subsection{Background}

The purpose of the chapter is to review the existing knowledge regarding the challenges faced by women technology entrepreneurs. The literature review utilized various sources, including books, journal articles, policy documents, and government publications. The key words used as search terms were "challenges", "female", "technology", "high technology" and "entrepreneurs". The literature review analyzes different barriers for females to start-up businesses in high-technology sector and to establish a sustainable market position.

The reviewed literature can be categorized into three main streams. The first literature stream considers the motivations of female entrepreneurs to launch and sustain their businesses in the high-technology sector. The second stream investigates the various challenges identified as either entry barriers or growth obstacles for high-technology female entrepreneurs. The third stream explores the female entrepreneurs and decision makers' possible strategies that can help to overcome perceived barriers or growth obstacles. The chapter concludes by discussing the limitations of these existing literature streams. 


\subsection{Importance of entrepreneurship and technology entrepreneurship}

The study focuses on female technology entrepreneurship. However, it is first essential to understand the characteristics of female entrepreneurship in general. To understand entrepreneurship, in general, and high-technology entrepreneurship, in particular, one needs to define them. The section provides definitions for entrepreneurship, technology entrepreneurship and differences between traditional sectors' entrepreneurs and technology entrepreneurs.

\subsubsection{Definition of Entrepreneurship}

Entrepreneurship is an important aspect in any economy because it is the engine of the value, jobs, consumption, investment creation and the taxpayer. It is a source of public income and a source of consumption creation. Schumpeter (1934) defined 'entrepreneurship' as a process of starting new business based on existing services and products. According to Scarborough and Zimmerer (2000), entrepreneurship means "being able to create a new business based on understanding the necessary resources and opportunities and taking risk in uncertain business environment to get good growth and revenue" (Scarborough and Zimmerer, 2000: 4).

In addition, entrepreneurs can create a business idea to improve the economy and increase the Gross Domestic Product (GDP) (Ireland et al., 2003). For example, entrepreneurs create new products, new consumption, and jobs via their investments (Bailetti et al., 2012). They create value added by creating good products to attract customers (Shane and Venkataraman, 2000). They do not content themselves to create unique and innovative products and services, but they add value to the community (Dollinger, 1999). This value added includes job creation and economic security. 
An entrepreneur is someone who creates innovative products whose functions are the improvement of the economy. A special attention must be given to entrepreneurs because it's their skills, aspiration, and willingness what keep the business going. According Ireland et al., (2003), the entrepreneurial mindset is defined as "a growth-oriented perspective through which individuals promote flexibility, creativity, continuous innovation and renewal" (Ireland et al., 2003). This study shares the above definitions and the view by Wickham (2004), according to which "entrepreneurs create new opportunities using their creativity and problem solving skills to attract other organizations from the business environment to share their resources and build strong business and entrepreneurial support network".

\subsubsection{Definition of Technology Entrepreneurship (TE)}

The entrepreneurship is very important for the economy because it is considered as the job creation engine. However, high-technology entrepreneurship is even more important because it presents the value and a job creation in the future economy. To understand the definition of technology entrepreneurship, Bailetti (2012) looked at over 90 articles and found that there are just six common definitions of technology entrepreneurship. According to him, technology entrepreneurship can be best defined as follows: "an investment in a project that assembles and deploys specialized individuals and heterogeneous assets that are intricately related to advances in scientific and technological knowledge for the purpose of creating and capturing value for a firm" (Bailetti, 2012, p 9).

Technology entrepreneurs identify the new market opportunities by understanding customers' needs and the ways these needs should be fulfilled while traditional entrepreneurs offer existing goods and services and compete with many other businesses in the market. They use technology to solve real world problems. These solutions must be compatible with current 
technology and customers' needs. In addition, technology entrepreneurs can upgrade old technology based on the customer environment changes.

\subsubsection{Difference between traditional entrepreneurs and technology entrepreneurs}

The majority of the existing articles fail to provide clear differences between the characteristics of technology entrepreneurs and entrepreneurs from other industries. Mezias and Kuperman (2000) found that larger business networks have large collective organizations that have larger resources and rapid growth (Mezias and Kuperman, 2000). Therefore, high technology entrepreneurs are able to develop better business relationships and greater business network with various organizations and businesses than traditional entrepreneurs because of the use of the technology that makes them able to make higher growth.

Technology entrepreneurs provide offerings that solve a contemporary customer problem while traditional entrepreneurs content themselves to selling existing products and services

(Scott, 2000). Traditional sectors' entrepreneurs face high competition while offering normal goods and services which imply slow business growth. High-technology entrepreneurs who make unique products are away from competition, and this enables them to earn high income and make higher business growth (Wunker, 2005). Furthermore, technology entrepreneurs offer their services to the entire world rather than to only local clients. They have creative ideas to develop the service and products based on the customer's needs (Wunker, 2005).

\subsubsection{Women entrepreneurship in Canada}

In 2012, there were 1,107,540 employer businesses in Canada. Small firms account for $98 \%$ of the total number of employer businesses in Canada. Between 2008 and 2009, the number of small firms employing at least one paid employee besides the owner increased by 22,000 . 
Approximately $57 \%$ of the total number of Canadian businesses with at least one employee located in Ontario and Quebec; this is due to the high population of the two provinces and the availability of funds since $68 \%$ of capital venture and angels located in these two provinces (Industry Canada, 2013; Cayen, 2001). The rest distributed as follows: 36\% located in the western provinces; $7 \%$ located in the Atlantic Provinces, and $0.3 \%$ located in Yukon and Nunavut (Industry Canada, 2013). The survival rate of small firms in Canada declined between 2007 and 2008; 72\% of SMEs that entered to the market in 2007 survived for two years while $80 \%$ of companies that entered the market in 2008 survived only for one full year. High-growth companies are not only concentrated in high-technology and knowledge based industries.

The employer businesses in Canada are distributed throughout the different business sectors. 1.08 million small employer businesses are concentrated in four main industries: $18.8 \%$ in the wholesale trade and retail, $11.7 \%$ in construction, $11.6 \%$ in professional, scientific and technical services, and $10.6 \%$ in other sectors. For medium-sized employer businesses, $52 \%$ are operating in wholesale trade and retail, $17.8 \%$ in manufacturing, and $11 \%$ in management of companies and enterprises and other support services. Figure 1 shows high-growth firms by business sector; the percentage of the number of high-growth companies in the construction sector is $5.7 \%$, the building and other support services (4.9\%), professional, scientific and technical services (4.5\%), and transportation and warehousing (4.8\%) (Industry Canada, 2013). 
Figure 1: High-Growth Firms by Business Sector.

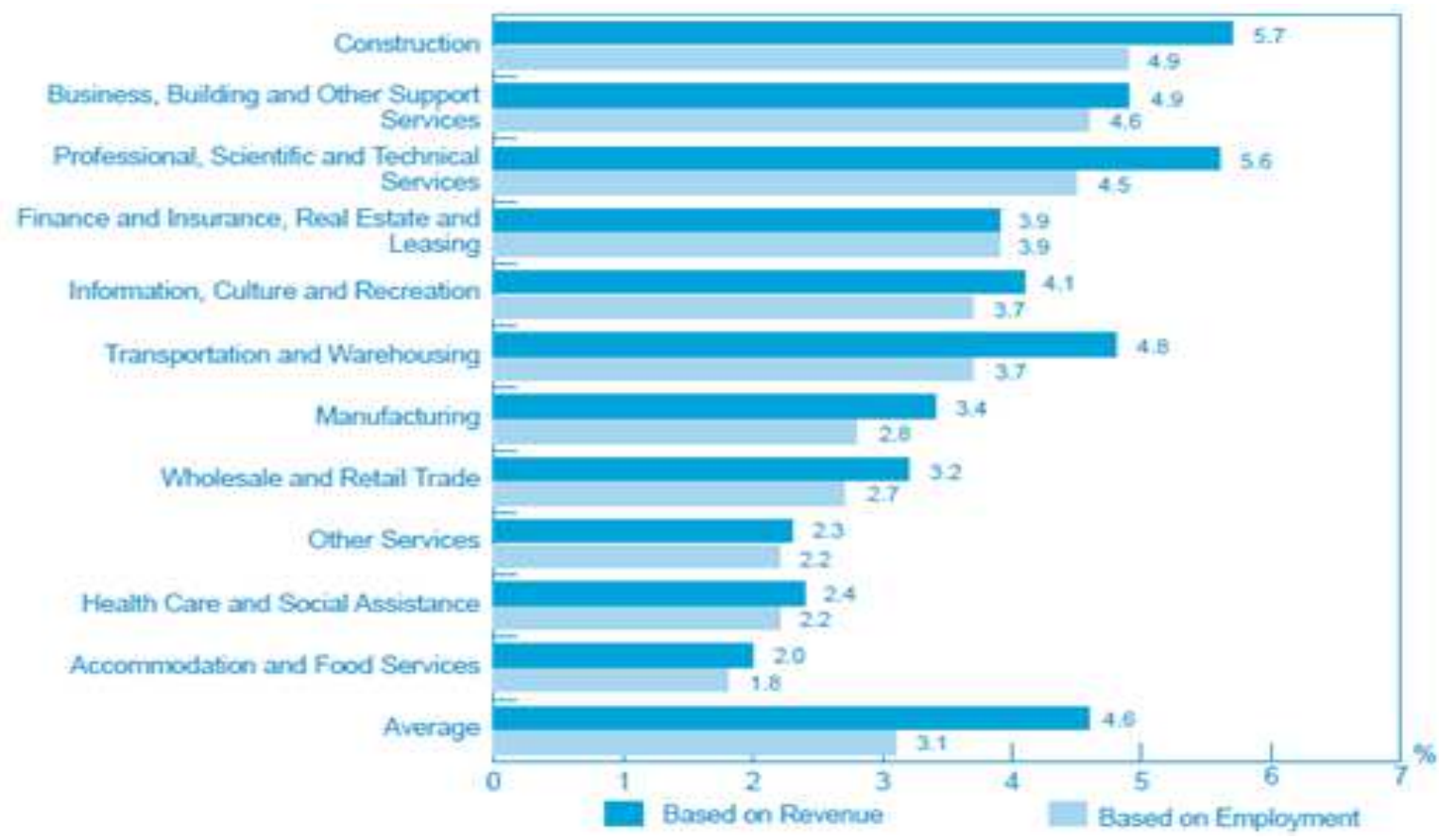

Source: Industry Canada, 2013

Figure 2 shows that in 2011 only $13.5 \%$ of small businesses were Female-only owned enterprises, 2.1\% Female-Majority ownership, 18.2\% Equal partnership while $53.8 \%$ of small businesses were Male-Only ownership and 14.4\% Majority Male Ownership. Moreover, only 4\% of medium size companies were Female-Only owned, 3.5\% were Female-Majority owned businesses and $9.9 \%$ were male and female equal partnership, while $66 \%$ of medium size companies were Male-Only owned companies and $12.4 \%$ were majority owned companies (Industry Canada, 2013). Other statistics state that female only or partially owned companies represent $47 \%$ of the total number of small and medium-sized firms in Canada. However, women entrepreneurs play a bigger role among visible minorities in Canada; aboriginal female wholly or 
partially owned companies represent $51 \%$ of aboriginal owned companies (TD Economics, 2012).

Figure 2: Business ownership with regards to gender distribution and business size

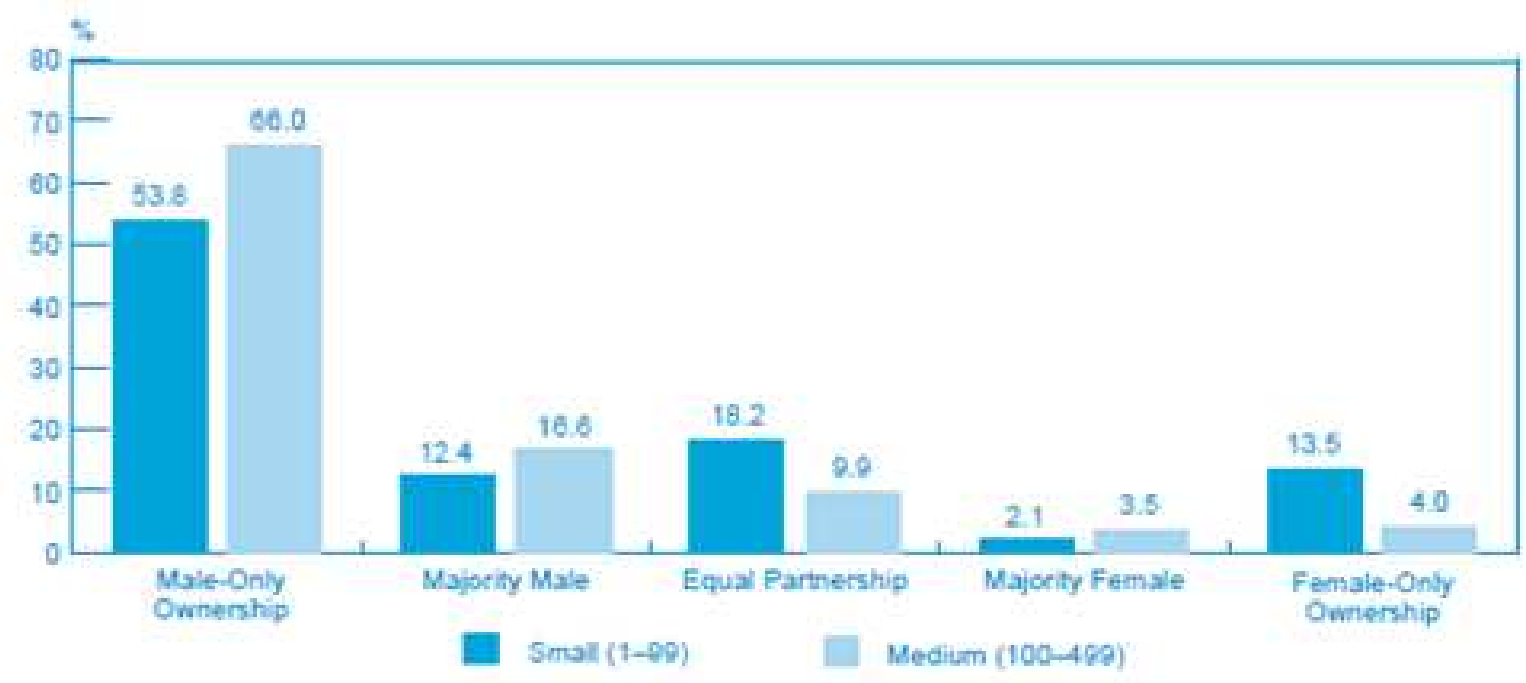

Source: Industry Canada, 2013

The survey conducted by Statistics Canada on Financing and Growth of Small and Medium Enterprises 2011 brings about different types of company ownerships. In the study, small businesses are businesses with 1 to 99 employees; medium businesses employ between 100 and 499 employees, and large businesses employ more than 500 employees (Industry Canada, 2013). According to TD economics (2013), the majority of small firm owners state that their major challenge during the first 3 to 5 years of operations is to attract or retain employees. Female entrepreneurs seek less financing than their male counterparts, approximately $18 \%$ of partially or wholly female owned Canadian small firms seek financing, which might explain by the risk aversion towards debt financing or Risk-To-Promise towards capital venture, angels, and grants financing (TD Economics, 2012). 
Female entrepreneurs' companies tend to have a slower growth rate compared to male owned companies. Simultaneously, the percentage of female entrepreneurs that expressed their intention to grow their companies is higher than those who want to keep their companies smaller. In 2004, although $41 \%$ of male owned businesses and $39 \%$ of women owned businesses intended to expand, during the following four years, male owned companies on average grew by $6.7 \%$ and female owned businesses' average growth was 3.9\%. The preferred activity for male owned companies is construction and the preferred sector for female owned companies is health care and social assistance sector (TD Economics, 2012). Appendix A provides more statistical information on women versus men entrepreneurs in Canada.

\subsection{Motivation and challenges of high-technology female entrepreneurs}

\subsubsection{Female Entrepreneurs' Motivations}

According to Cromie (1987), female entrepreneurs want to be independent and flexible to be able to balance their personal and professional responsibilities. As a result, the number of female self-employed has increased in Canada over the last 20 years (Brwon et al., 2002). They are encouraged to be self-employed to balance between both household and business responsibilities (Brwon et al., 2002). There are different reasons behind females' motivation to have their own business especially in high-technology sector. The first reason to start-up their own business is the financial opportunity because they can determine their earning and increase it with every opportunity to grow (Industry Canada, 2005). Additionally, desire for selffulfillment is another reason because they want a better status and social recognition (Hessels, 2007).

According to Belcourt (1990), up to $60 \%$ of the interviewed women business entrepreneurs' fathers were entrepreneurs. The closeness and favoured position of daughters to 
their fathers facilitate their way to play non-traditional role as entrepreneurs especially if this closeness to the father is associated with rejection from mothers. A total of $67 \%$ of respondents said that they opted for entrepreneurship because they wanted to take their destiny between their hands. $45 \%$ of interviewed females said that they could not rely on their husbands for the following reasons: their husband could not keep a job (11\%), lack of husband's ambition (8\%), alcoholism problem (6\%), affairs (6\%), business failure (6\%), abusive behavior (3\%), and gambling (3\%). Also, as many as $45 \%$ of interviewed female entrepreneurs said that they did not choose to work for companies because they could not fit within the corporate world as employees; $17 \%$ of them said they were fired, $17 \%$ because of employers' discrimination, and $11 \%$ because they were unable to find work (Belcourt, 1990). In the United States, the non-farm self-employed females' rate increased from 4.1\% to $6.7 \%$ between 1990 and 1995 . On the other side, self-employed females not only gain significantly less amount than self-employed men but they also earn significantly less than employed females (Devine, 1994).

Also, for some entrepreneurs, the entrepreneurial work satisfaction resides in dealing closely with customers and employees. Thus, many entrepreneurs feel that the growth of the company will decrease the joy of this satisfaction, and consequently they prefer to limit the growth of their companies (Gundry and Welsch, 2001). Furthermore, they like to launch businesses within areas of interest to them because the background and experiences they have encourage them. Hughes (1999) discusses the reasons as to why some women choose to be selfemployed. He concluded that they are either pushed by society or they are attracted by entrepreneurs' financial situation. TD economics (2012) shows that $71 \%$ of male and $53 \%$ of females in Canada enter to the entrepreneurial career because of the classic pull factors like independence, being one's own boss, higher income as well as challenge and creativity. 
Morevoer, $22 \%$ of both men and women make the choice to pursue an entrepreneurial career because of the lack of alternatives, and $7 \%$ of men and $25 \%$ of women entered the business world in order to take over the family business.

Lin (1999) gives two hypotheses to understand why women are attracted to entrepreneurship. He said that they are either motivated by the "recession push" and/or "entrepreneurial pull". The "recession push" hypothesis says that women are pushed to be selfemployed because there are no high paying employment opportunities. So, they tend to create their own business to be highly rewarded for their work. The "entrepreneurial pull" says that women are pulled to be self-employed because they like the entrepreneurial status in the society. Female entrepreneurs are, also, influenced by family members and friends to start-up their own businesses.

Braguinsky et al. (2009) studied how motivation influences females to start an entrepreneurial career. According to them (ibid.), most entrepreneurs are driven by the personal benefit and the high income and high social status. Aspects like creating jobs are secondary for them (Shane et al., 2003). Motivation encourages entrepreneurs to continue and try different ways until they succeed (Baum et al., 2000). When entrepreneurs find partners who share the same interests and skills, they can motivate each other to set up businesses (Hamilton, 2000). However, Buttner and Moore (1997) argued that women entrepreneurs are mostly motivated by determination to succeed. They may prefer to create their own ideas without asking for support from mentors (Buttner and Moore, 1997).

Dawson and Henley (2012) mentioned the "push" and "pull" factors that encourage people to become self-employed. The interesting finding of their paper is that "pull" factors are more likely to inspire men to be self-employed but both "push" and "pull" factors combined 
encourage females to be self-employed. However, the reasons for the females' high likelihood to start up a business is because they are influenced by motivational "push" factors such as family and personal responsibilities and the need for a flexible time job to manage their responsibilities. The main issue here is that females prefer to create traditional businesses rather than high technology related businesses (Carrington, 2006).

When we look at technology entrepreneurs, the main reason for women to be motivated is the high reward of the entrepreneurial career. Mostly, women think that they should be financially well-established to be able to start-up a company (Lindh and Ohlsson, 1996). There is a belief that being financially stable while starting a high-technology company will guarantee wealth in the future and it is estimated that lower income people struggle to set up businesses, especially in the high-technology field (Cabral and Mata, 2003). However, Amit et al. (2000) augmented that being wealthy is less important than being innovative at the early stage of business. This means that a skillful, innovative and experienced entrepreneur is more likely to succeed in the industry regardless their financial situation (Amit et al., 2000). Moreover, Wiklund et al. (2003) conclude that technology entrepreneurs are more concerned about the project's general outcome (financial outcome, customer satisfaction, value creation, job creation, and problem solving) rather than thinking about the money spent to settle the company (Wiklund et al., 2003). The reason is that they concentrate on using the right technology to solve problems for customers and gaining higher profits which brings high returns in the future. 
Figure 3: "Pull" and "Push" Factors into Entrepreneurship

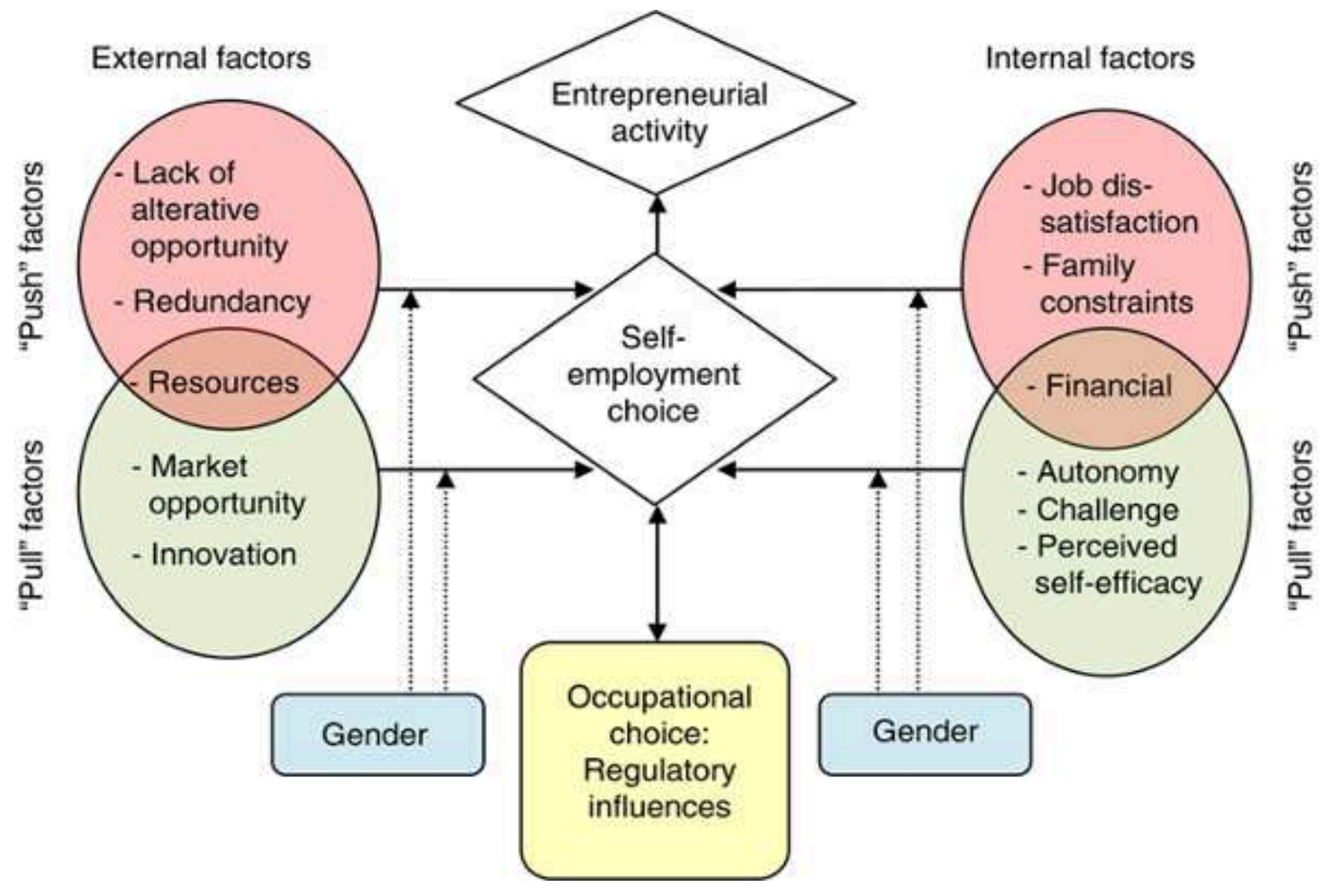

Source: Dawson \& Henley (2010)

Figure 3 illustrates that there is a reverse causality between the occupational choice (regulatory influences) and the self-employment choice (they mutually affect each other). This model by Dawson and Henley (2010) suggests that after one makes a decision to be selfemployed the entrepreneurial activity starts. The self-employment choice is affected by external and internal factors. External and internal factors are divided into pull and push factors. The external push factors are the lack of alternative opportunity, redundancy and the availability of resources while the external pull factors are the market opportunity, innovation, and resources. The internal push factors are the job dissatisfaction, family constraints and the financial resources while the internal pull factors are the financial outcomes, autonomy, challenges, and perceived self-efficacy. Gender issues affect external and internal pull and push factors. 


\subsubsection{Growth Control}

Previously, it has been argued that women entrepreneurs limit the growth and the size of their businesses because they want to keep their companies manageable as they want to balance between their family and work commitments (Gilligan, 1982). Consequently, the house becomes the management headquarters, operating and distribution facility and, in most cases, the household income finances the business (Longstreth et al., 1987). Moreover, 55\% of selfemployed women spend less than 35 hours per week working on their businesses (Devine, 1994).

In addition to balancing between work and personal life commitments, risk aversion plays important roles for women in choosing an entrepreneurial career (Siddiqui, 2008). Consequently, women entrepreneurs are more likely to restrain their businesses' growth. According to TD economics (2012), 25\% of females who opted for an entrepreneurial career because of their need to balance between their work and family commitments are more likely to restrain the growth of their companies to maintain this balance. As compared to their male counterparts, female entrepreneurs seem to set a maximum growth threshold beyond which they are not interested to go, and if men entrepreneurs happen to set maximum growth threshold they tend to set a higher threshold than that of women. This propensity among females to pursue a lower or restrained growth explained the small number of female owned companies among exporting companies (TD economics, 2012).

On the other side, between 2001 and 2011, the wages of employed females, aged 25 to 54 , significantly increased by $13 \%$ compared to $5 \%$ increase in males' wages. The increase in the paid work rewards encourages women to look for paid work rather than pursuing an entrepreneurial career, which increased females' presence in the paid jobs market by $8 \%$ during the same period. Other policies and programs such as the Universal Childcare Program and the 
Parental Leave Program give more time flexibility to mothers who encourage more women to opt for paid jobs instead of pursuing an entrepreneurial career (TD economics, 2012). Given that entrepreneurs are required to spend more time working on their businesses, $40 \%$ of entrepreneurs spend more than 50 hours a week; mothers are more attracted to paid work. Furthermore, among 168 self-employed women across Canada, most of them had difficulty having some time off for maternity/parental leave or sick leave ( 1 on 3 female entrepreneurs returned to work within two months of having a child) (TD economics, 2012).

One explanation for the growth limitation of women-owned businesses is the limitation of resources. Two sets of resources enable the entrepreneur to grow the business; the human capital allowing the entrepreneur to lead the business, and the ability of the entrepreneur to acquire resources necessary to grow the business such as capital, customers and suppliers (Chusmir, 1983). However, according to a recent study by Brush et al. (2006), only 7\% from 466 surveyed women enterprises' owners stated that they want to control the growth of their businesses and $93 \%$ of respondents seek growth at both national and international levels. In addition, a total of $56 \%$ of respondents owned equity in a prior start-up company.

\subsubsection{Challenges Faced by Female Entrepreneurs}

In Canada, the self-employment rate increased by $0.3 \%$ points for men and decreased by 0.5\% points for women between 1999 and 2004 (Statistics Canada, 2004). Moreover, as of 2000 only $15 \%$ of Canadian small-and medium sized enterprises (SMEs) were female-led, while menled SMEs were 67\%. Women-led SMEs were reported to be smaller than men-led SMEs. Furthermore, female-owned SMEs are reported to be often less incorporated, smaller in grandeur of operations and number of employees. They are, also, described as lower growth companies that are less inclined for exporting than male owned SMEs (Menzies et al., 2006). Table 1 shows 
that $33 \%$ of the female entrepreneurs interviewed held a certificate in administration, accounting and math, health and natural resources $24 \%$ while only $4 \%$ of them held degrees in applied sciences and computers against $32 \%$ of male entrepreneurs holding degrees in applied sciences and computers. As for the company ownership, $14 \%$ of males and $8 \%$ of females indicated they own most of their companies while $31 \%$ of males and $41 \%$ of females indicated they own just a part of the studied companies. 54\% of male respondents stated that they had previous experiences in the field of their investments while only $54 \%$ of female respondents said they had previous experience in the field of investment (Menzies et al., 2006). See Table 1 for details. 
Table 1: Personal and Business Characteristics with Gender Differences

\begin{tabular}{|c|c|c|c|c|c|c|}
\hline & $\%$ Male & $\%$ Female & Total $\mathrm{T}$ & $N$ & Mean & SD \\
\hline \multicolumn{7}{|l|}{ College or University Major:** } \\
\hline Administration, Accounting, Math & 24 & 33 & 27 & & & \\
\hline Health and Natural Sciences & 10 & 24 & 15 & & & \\
\hline Applied Sciences and Computers & 32 & 4 & 22 & & & \\
\hline Education, Social Services, Arts & 20 & 15 & 18 & & & \\
\hline None/Other & 15 & 24 & 18 & & & \\
\hline Are you the owner of the residence you live in? *Yes & 70 & 54 & 64 & & & \\
\hline \multicolumn{7}{|c|}{ What percentage of household or child tasks do you do? *** } \\
\hline Male & & & & 87 & 47.6 & 32.0 \\
\hline Female & & & & 53 & 74.7 & 27.4 \\
\hline \multicolumn{7}{|l|}{ Business ownership among close friends and neighbors: } \\
\hline Most** & 14 & 8 & 12 & & & \\
\hline Some & 31 & 41 & 35 & & & \\
\hline Few & 46 & 25 & 39 & & & \\
\hline None & 9 & 25 & 15 & & & \\
\hline Previous startup experience? **Yes & 54 & 28 & 44.6 & & & \\
\hline None & 46 & 72 & 55.4 & & & \\
\hline \multicolumn{7}{|l|}{$\begin{array}{l}\text { What is the like hood that this business will be operating } \\
\text { five years from now?* }\end{array}$} \\
\hline Male & & & & 88 & 85 & 21.4 \\
\hline Female & & & & 51 & 76.0 & 28.0 \\
\hline Company is hi-tech: No or Not Applicable*t & 65 & 85 & 72 & & & \\
\hline Yes & 35 & 15 & 28 & & & \\
\hline \multicolumn{7}{|l|}{ Source of Expected Customers (Percentage)** } \\
\hline Local: Male & & & & 87 & 49.8 & 38.3 \\
\hline Female & & & & 53 & 70.2 & 32.1 \\
\hline Intemational: Male & & & & 82 & 21.4 & 35.3 \\
\hline Female & & & & 50 & 7.6 & 17.0 \\
\hline
\end{tabular}

Note: $p<0.05^{*}, p<0.01^{* *}, p<0.001^{* * *}$

Source: (Menzies et al. 2006)

According to Bruin et al. (2009), getting the necessary funds is one important component in creating successful high technology companies. Female entrepreneurs face challenges such as lack of access to information and assistance, lack of access to capital, and females' socio-cultural status including their families' obligations (Bruni et al., 2004). In 2011, the number of selfemployed females was 950,000. Their number grew by 23\% between 2001 and 2011 (Government of Canada, 2012). Almost half of Canadian small companies are, wholly or partially, owned by women. However, a very small number of high-technology start-ups are 
owned by females (Johne, 2012). The growth in the high technology sector and the number of female entrepreneurs improve the Canadian economy because it creates more job opportunities, more consumption, saving, investment and use of human capital.

Technology entrepreneurship is a new phenomenon in recent years. Therefore, the lack of funds and lack of business skills are among the significant challenges facing high-technology female entrepreneurs in Canada. When high technology female entrepreneurs create business ideas, they present them to capital market for funding. However, investors and funding institutions find it hard to choose between promising business ideas that can pay back (Guiso et al., 2004). Most of the proposed business plans are refused because entrepreneurs cannot answer some questions like "how are you going to make a profit?" Women usually find their way around this problem. Female entrepreneurs usually borrow money from their friends and family members rather than applying for funding (Prime Minister's Task Force on Women Entrepreneurs, 2003).

Different reasons make investors reluctant to fund new female entrepreneurs' projects. First, female entrepreneurs open less interesting businesses for investors such as retail businesses. Second, the lack of business network is another reason to avoid applying for investors' funding, because entrepreneurs are unaware how to get to know investors. Third, technology entrepreneurs' education is the basis to become a successful entrepreneur. Thus, the right education (business education) enables high technology entrepreneurs to plan for future ventures. Management skills come from experience and education. Management skills make entrepreneurs well-rounded and able to open up successful business ventures (Baldwin et al., 1997). 
When applying to governments and/or private companies for funding; entrepreneur must show promising signs that their ventures will be successful. When assessing whether the new venture will be successful or not, funders analyze the entrepreneur's background because it influences the likelihood of their businesses' growth or bankruptcy. Furthermore, the size of the business is an important factor that is taken into consideration because small local businesses require little funding, unlike big ones. However, technology companies need larger amount of funds to carry on their operations while developing their new product (Fluck et al., 2000).

Many high-technology female entrepreneurs in Canada faced challenges to start-up high technology businesses (Johne, 2012). Female entrepreneurs in general are struggling because of the lack of clear female entrepreneurs strategic help by the government of Canada. Many of these women did not get necessary funds to start-up high technology businesses because they are afraid of promising to return the money (females receive only $2.3 \%$ of the total Canadian institutional investment money) (Industry Canada, 2012). When women entrepreneurs present their business ideas to private venture capital organizations or policy makers they are seen as not trustworthy even if they present sufficient collaterals (Trichur, 2011). For this reason; female entrepreneurs tend to use their personal funding or other private financial resources (Industry Canada, 2012).

High-technology female entrepreneurs face remarkable challenges to create innovative businesses. According to Cliff (1998), practical education helps females to come up with technologically innovative business ideas to start-up successful technology companies. The lack of business and management skills impacts the high-technology female entrepreneurs (Cliff, 1998). According to Cliff (1998), women are less likely to hold a business degree than men do ( $9 \%$ of females hold a business degree against $23 \%$ of men). Not only many female 
entrepreneurs fail in high-technology sectors because of the effect of insufficient business and management skills, but they also frequently lack professional business network. Several scholarly works address the need of business network to improve the outcome and the sustainability of the business for both genders (Alison Hampton, 2011).

Another less important barrier of high technology female entrepreneurs to start-up businesses is family responsibilities (Cliff, 1998). Females are reluctant towards the growth because they tend to refrain the growth of their companies as they think that this will create a conflict between their corporate work and family obligations (Cliff, 1998). However, the fear and anxiety of being able to handle both responsibilities is a challenge (Cliff, 1998). Both lack of innovation and business skills affect high technology female entrepreneurs affect the company Christensen (2003). The absence of right education has been found to be among the main challenges facing the high technology female entrepreneurs.

\subsubsection{Female Entrepreneurs and Funds (Lack of Financial Support)}

There are different methods for financing in the business world. This section presents venture-capital, bootstrapping, angel investors as well as the turndown rate differences between male and female entrepreneurs. The thesis does not concentrate on debt financing because obtaining loans from banks is not a female entrepreneurs' exclusive challenge because they are often treated equally to men. Both genders are required to present collaterals to make sure they pay back the loan in case of defaults. The challenge rests on obtaining grants from investors, government, and companies because in general, female entrepreneurs who seek funds are underestimated and not necessarily trusted with large amounts of money (Mahbub, 2000). Business stakeholders look at entrepreneurs as individuals rather than looking at the entrepreneurs as part or of a legal entity (Mezias, 2000). 
Empirical evidence shows that females obtain less money from venture capital because they apply less for external funds (Brush at el., 2002). Obtaining enough funds to finance the operations and the high labor cost are considered as financial barriers for female entrepreneurs (Kamaruzzaman et al., 2008; Headd, 2003). Although limited funding does not encourage women to set up business in high-technology sector, entrepreneurial activities and high social status have influenced women in their job choices. In addition, women do not borrow money from banks because they start-up small local businesses that are less attractive to investors (Verheul and Thurik, 2000).

Figure 4 illustrates that funding is one of the four most important interrelated business environment components. For a business to operate successfully and grow in the market; all components must work together. High-technology female entrepreneurs are required to acquire necessary funds to stay in business and develop their innovative technological ideas as a part of the business environment components (Cooper and Park, 2008)

\section{Figure 4: 5-M Framework}

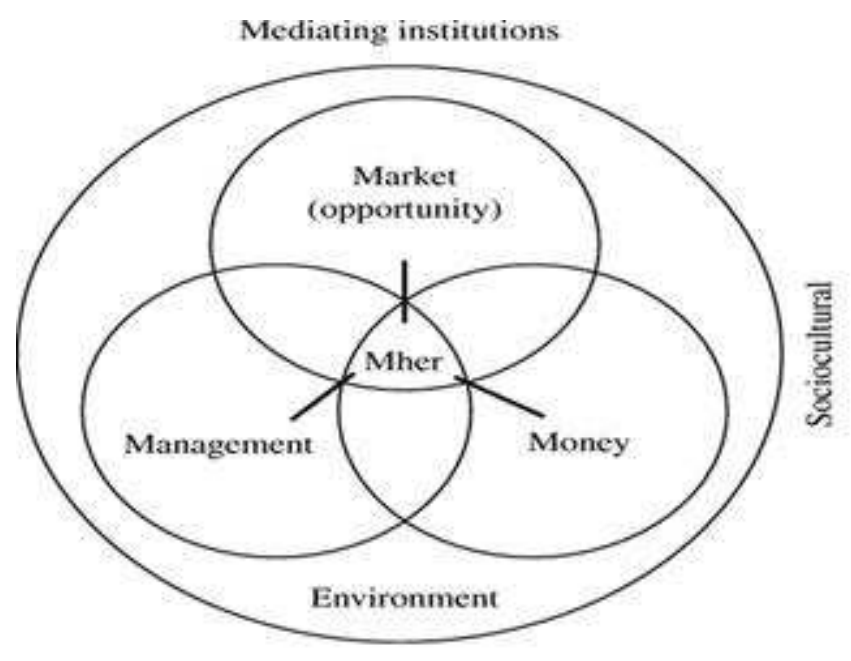

Meso environment:

spatial embeddedness

Macro environment:

institutional embeddedness

Micro environment/motherhood:

'family' embeddedness

Market, management, money: business embeddedness

Source: Bruin et al., (2009) 
Turndown rate. Small businesses are less interesting to investors because they grow slowly. According Katz and Green (2007), there are 11 characteristics of small size business, such as limited development, short-term strategy, less growth and they rarely offer hightechnology innovative products and services (Katz and Green, 2007). These characteristics participate in the rejection of investment proposals and the increase in the turndown rate. Table 2 shows that the percentage of women-owned companies' loan applications turndown is higher than the turndown for male applications (22.4\% rejection rate for women against $18.1 \%$ rejection rate). A possible explanation to this difference is the existence of gender differences in the way of doing business, as women are less likely to have a formal business plan (Alsos and Ljunggren, 1998). There is an evidence of homophily from the part of entrepreneurs while seeking funding. Entrepreneurs tend to look for funding from angels from the same sex which leaves women with narrow options given the small number of women angel investors ( $2 \%$ of the total number of angel investors in Canada in 1993) (Becker-Blease and Sohl, 2007; Harrison and Mason, 2007).

\section{Table 2: Turndown Frequencies by Gender and the Types of Financing}

\begin{tabular}{|c|c|c|c|c|c|c|}
\hline & \multicolumn{2}{|c|}{ Loan applicants } & \multicolumn{2}{|c|}{ Lease applicants } & \multicolumn{2}{|c|}{$\begin{array}{l}\text { Applicants for } \\
\text { supplier financing }\end{array}$} \\
\hline & Men & Women & Men & Women & Men & Women \\
\hline Tumdown rates & $18.1 \%$ & $22.4 \%$ & $2.8 \%$ & $0.0 \%$ & $12.2 \%$ & $14.4 \%$ \\
\hline $\mathrm{N}$ & 542 & 85 & 285 & 39 & 663 & 104 \\
\hline$t$-values & -0.94 & & 2.86 & & -0.63 & \\
\hline$p$-values & 0.348 & & 0.004 & & 0.528 & \\
\hline
\end{tabular}

Source: Orser et al. (2006) 
Venture capital. Financing market available for Canadian ventures is divided into submarkets. This thesis looks into ventures-capital, angel investors, financing debt, and bootstrapping. The total amount has been increasing over the years by an average annual growth of $21 \%$ from 1991 to 2000 . The venture capital has increased faster and bigger than any other form of financing source in Canada. However, despite this high growth in the venture-capital, it only represented $2.3 \%$ of the business credit stock in Canada in year 2000. The high growth of the venture capital is associated with the growth of the economy. High technology sector is the main beneficiary from the capital venture investments. In 2000, $89 \%$ of venture-capital investments were in the high-technology sector while it was only 46\% in 1993 (Cayen, 2001).

Venture-capital investment decision is based on certain characteristics. The investment in high-technology sector favours communications and computers companies. Also, venture capitalists tend to invest in companies in their expansion stage rather than companies at early stages of growth. Historically, companies that are at large expansion have benefited from $50 \%$ of venture capital investments. On the other side, small companies have benefited from a smaller part from the venture capital ranging between $25 \%$ and $36 \%$ from to 1999 . Figure 5 shows that Ontarian and Quebec companies are also more favorable than other companies from other regions in Canada because the majority of venture capitalists are concentrated in Ottawa and Toronto areas. Ontario contains $47 \%$ of the total venture capital stock available in Canada and Quebec contains $21 \%$ of it. 
Figure 5: Geographical Distribution of Venture-Capital Investment in 2000

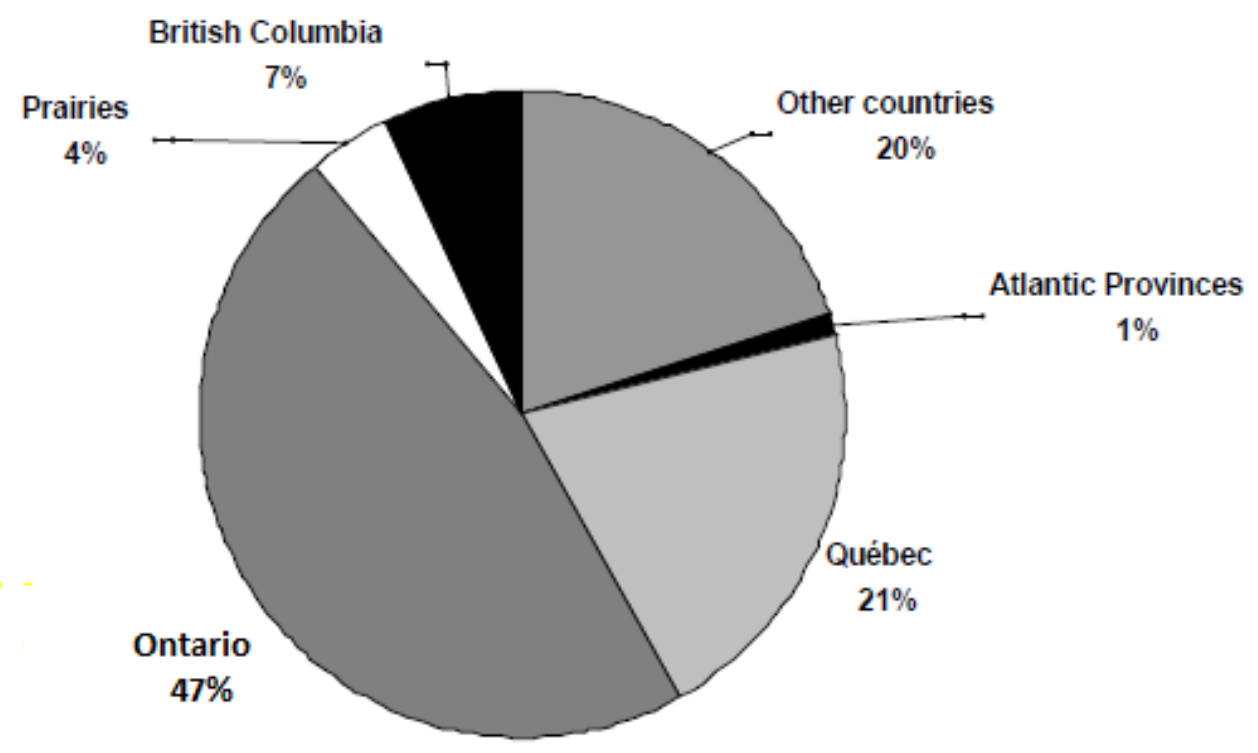

Source: Cayen, (2001)

Figure 6 shows that in 2000, government owned funds represented $2 \%$ of these venture capitals, corporate funds $8 \%$, private independent funds $15 \%$, labour-sponsored funds $12 \%$, institutional funds $24 \%$ and foreign investors $24 \%$ (Cayen, 2001).

Figure 6: Sources of Venture Capital Invested in 2000

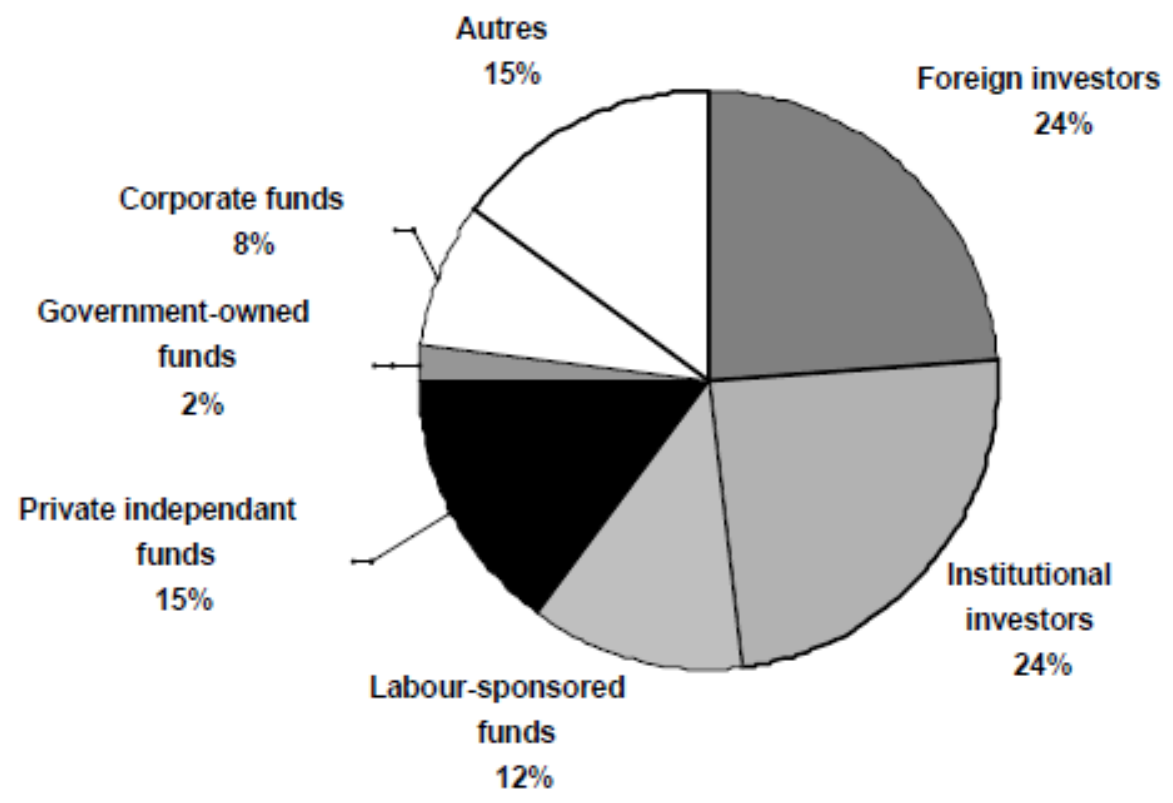

Source: Cayen (2001) 
For instance, The F Capital is the only venture capital specialized in financing women. Approximately 43,000 women-led business in Canada meet the basic requirement of F Capital's investment criteria (minimum three years of operation and annual review over $\$ 500,000$ in sciences or high technology fields) but only $5 \%$ of all venture capitals in Canada go to womenled businesses (Jennings and Cash, 2006).

Bootstrapping. The stereotype that female entrepreneurs are not trustworthy to handle large amounts of money serves as a significant setback (Bruni et al., 2004). On the other hand, Bennet and Dann (2000) argue that women prefer to use internal financial support such as borrowing money from family and friends, whereas men use more external resources such as borrowing from private banks. Table 3 illustrates that $85 \%$ of 2,357 surveyed men and $83 \%$ of 487 surveyed women indicated that as company owners they did not look for financing because they did not need it. $2.35 \%$ of males and $3.85 \%$ of women respondents said that they did not seek financing because they thought it would be turned down. Also, $4.44 \%$ of male and $5.77 \%$ of women stated that they did not apply for external financing because they disliked being in debt (Orser et al., 2006).

\section{Table 3: Reasons for Not Seeking Financing}

\begin{tabular}{lccc}
\hline & $\begin{array}{c}\text { Primarily male } \\
\text { ownership }(\%) \\
(\mathrm{N}=2,357)\end{array}$ & $\begin{array}{c}\text { Primarily female } \\
\text { ownership }(\%) \\
(\mathrm{N}=487)\end{array}$ & $p$-values \\
\hline & & & 0.491 \\
Financing not needed & 85.23 & 83.79 & 0.168 \\
Thought the request would be tumed down & 2.35 & 3.85 & 0.828 \\
Applying for financing is too difficult & 3.53 & 3.30 & 0.349 \\
Applying for financing is too time consuming & 1.96 & 2.75 & 0.972 \\
Cost of debt financing is too high & 1.90 & 1.92 & 0.321 \\
Do not like to be in debt & 4.44 & 5.77 & 0.733 \\
Other & 10.92 & 11.54 & \\
\hline
\end{tabular}

Source: Orser et al. (2006) 
Most of the firms at early stages get their financing from the founders and their families and friends. This financing is called the "love money". This money is used to finance the companies on the short-term. These resources are exhausted and are not enough for the company's development (Liu, 2000). Around 280,000 businesses in the U.S. are led by women; however, the majority of them are financed through personal resources such as personal savings, credit cards, personal debts and even commercial debts. Only few of these companies are able to have access to venture capitalists. Less than $5 \%$ of equity investments are made by led-women businesses (Green et al., 2001).

There is another hypothesis to explain the low proportion of equity investment. Jennings and Cash (2006) argue that women choose to not grow their businesses because they want to keep their companies under control. Female entrepreneurs like to limit the growth of their companies to be able to manage both family commitments and workload. Other authors argue that women-led businesses receive less capital-venture investments because they are concentrated in highly competitive and limited growth sectors while women who are operating in high-technology succeeded to get equity (Jennings and Cash, 2006).

Angel Investors: Estimates tell that the outstanding stock of angel capital was greater than $\$ 12$ billion and the annual after tax compensation was estimated to be $\$ 3$ billion in 1999 . After the exhaustion of personal resources, female high-technology entrepreneurs seek a transitional funding to continue their development. Bank financing is out-of-reach for most of the entrepreneurs because this funding is collateral-based (Liu, 2000). As a result, the stock of angel investors appears as a solution for women entrepreneurs to bridge the gap between venturecapital investment and the love money. Some estimates state that the angel financing market exceeds the venture capital stock in Canada. According to Riding and Short (1988), the annual 
growth of angel financing stock was between $\$ 200$ and \$400 million in the late 1980s. In 1999, angels' capital stock was estimated to be more than $\$ 3$ billion which represents $7 \%$ of the bank business landing market (Liu, 2000). In 1995, the Canadian Labour Market and Productivity centre estimated that angels financed almost twice as much as any other equity investment.

Typical angels are on average 50 years old, $99 \%$ of them are male, willing to invest between $\$ 50,000$ and $\$ 250,000$ in fields they are familiar with as current or former small business owners (Riding, 1998). Investments made by angel investors are below $\$ 1$ million. They participate in the management of the companies that they finance as mentors and consultants. Between 1993 and 1997, 73\% of angels' investments were made in Ottawa region because of the high concentration of information and communication technology companies. $77 \%$ of angels prefer investments that are lower than $\$ 150,000.48 \%$ of angel invest made their investments in companies at the seed stage while, and $72 \%$ invested at start-ups. Contrarily to other financing forms, angel investors investing decision process does not exceed six weeks. Projects rejection rate for angel investors is $72.6 \%$ because of the non-convincing financial return and/or the abilities of the investor to succeed. The high rejection rate is also due to due to the exaggerated valuation of the company or the lack of product and market knowledge. Angel investors' after-tax income rate is between $30 \%$ and $40 \%$.

The federal government is doing big efforts to encourage angel investors. The taxable portion on capital income was reduced from $75 \%$ to $66.67 \%$ in 2000 . Investors benefit from the privilege of onetime $\$ 500,000$ tax free capital gain. The government's monetary policy affects the demand on angel investments. When the government raises (lowers) the overnight interest rate, this raises (lowers) the bank interest rate on deposits and loans which make the demand for traditional bank financing contracting (expanding) and consequently causes demand on angel 
investors to increase (decrease) (Liu, 2000). According to Becker-Blease and Sohl (2007); women entrepreneurs received less funding from angel investments. They (ibid.) also state that female entrepreneurs apply less for funding from angel investors (only 8.9\% of business proposals were submitted by females). From 2000 through 2004, the rejection rate for proposals forwarded by females $(13.33 \%)$ was lower than the rejection rate for male applicants (14.79\%) (Becker-Blease and Sohl, 2007).

\subsubsection{Risk to Promise}

Female entrepreneurs avoid applying to investors and funding institutions because they do not want to promise a payback or a business growth while they are unsure about the success. Since the business environment is very challenging, it is often difficult for a new company to survive which increases the payment default's risk (Kortum and Lerner, 2000). In many cases, entrepreneurs fail to return the funds to the financial institution. Even if the fund providers get paid back from collaterals provided in the beginning, they are reluctant to provide entrepreneurs with future funds unless the risk of default is low. The venture capital investment dropped from $\$ 5.9$ billion in 2000 and reached 1.1 billion in 2010 due to unsuccessful venture ideas (Alpha, 2012). Technology female entrepreneurs need a relatively long time to develop products especially if they do not have enough funds.

\subsubsection{The insufficient business network challenge}

The entrepreneurial process is divided into two stages. The first stage consists of identifying the profit and business opportunity and the second stage consists of assembling resources required to start, operate and grow the business (Packard and Packard, 1995; Katz and Gartner, 1988). Business networks play an important role in the entrepreneurial journey. It helps companies to grow their market share and start new projects because of the knowledge, experience and connections sharing (Hanson and Blake, 2009). The knowledge, connections and 
experience sharing is vital because it helps the company to benefit from precious information, find solutions to their problem and use connections to overcome business problems. In addition, shedding light on experiences allows each company within this network to learn how to communicate efficiently with customers and find solutions to their managerial, financial and technological problems.

Business networks are either large or small. There is a general assumption that only large male-led business networks are successful because male entrepreneurs are successful in communicating with other entrepreneurs or members working in the venture capital market. However, in a fast growing number of entrepreneurs in different types of businesses, it is difficult to communicate with each other easily.

Female entrepreneurs build smaller business network than male entrepreneurs do. One reason for this is that women put more emphasis on their relationships with peers and family. In comparison, men put less emphasis on the family, so they have an advantage to create strong relationships with external actors. When compared to their male counterparts, research shows that females are unaware about how to choose the right beneficial connections for them (Renzulli et al., 2000; Greene, 2003). Female entrepreneurs build relationships more than business connections; this means that not every member in their network is helpful. Thus, even if their networks are large only few of their connections are beneficial. Moreover, regardless the lack of funds, a support network is important to communicate with important people in the company's environment such as policy makers who can help them get funds and solve their problems (UNECE, 2004). 
Based on all of the above, women should get in touch with another business network member who is capable and willing to help them get funds and provide them with another support (Reynolds, 2002). According to Ford et al. (2003), there is no company in the business environment that has the necessary skills, technologies and resources to respond to the environment's requirements and solve others' problems.

\subsubsection{Lack of business and management skills}

According to Arai (1997), entrepreneurs tend to create unsuccessful businesses because of the insufficient knowledge and business experience and poor management skills. Many female entrepreneurs set up businesses while they lack the necessary management knowledge and experience to succeed. The entrepreneurs' background (family and social background) pushes them to start-up businesses even if they lack the required managerial knowledge. On the other hand, many individuals avoid going for entrepreneurial career path because they are worried from failure. Since there is a chance of failure, they tend to focus on attaining other careers. However, those who become entrepreneurs and achieve success are treated as role models in the community (Entrepreneurs speak out-article). Thus, high-technology female entrepreneurs and females who are interested in the start-up business in the technology sectors, especially those who have less business experience, should enter business schools and learn the required managerial skills (Gupta et al., 2009).

Education is a key factor that opens many doors for those individuals who plan on becoming entrepreneurs. Achieving right post-secondary education in business and management helps students get non-traditional businesses and encourage them to broaden their horizons. Many female individuals tend to focus on creating traditional businesses such as retail, car dealerships and service companies. Although education plays a pivotal role in the success of high 
technology companies, it is not the only contributing factor. Management skills are needed for any high-technology company to progress. These skills acquired through education and previous experiences in the business and management field. Important factors in measuring management skills include planning, formulating goals, decision-making, motivation, marketing, accounting, and negotiation skills (Kamalanabhan, 2000).

Ibrahim and Soufani (2002) find that $18 \%$ of female start-up founders said they had MBAs, $31 \%$ of them have Master's in other fields other than Company Operating Activity and MBA, and 5\% with PhDs. 53 universities in Canada offer entrepreneurship courses and SMEs management in order to enhance managerial skills of both future and existing entrepreneurs (Brush et al., 2006). 32 Canadian universities offer entrepreneurship training in specialised entrepreneurship training centre (Ibrahim and Soufani, 2002). 40\% of students who attended entrepreneurship courses ended up starting their own businesses, 30\% joined their families' businesses while $30 \%$ joined the corporate world as employees worked for large organizations (Ibrahim and Soufani., 2002; Upton et al., 1995). According to Menzies and Paradi (2003), 40\% of Canadian engineering schools' graduates who attended entrepreneurship courses and training started their own small businesses.

Many firms have failed to create and grow their competitive advantage because they failed to adapt their business model to the new technology (Chesbrough and Rosenbloom, 2002). One approach that would allow these firms to change their business models is by experimenting and adopting organizational leadership (Chesbrough, 2009). Doz and Kosenen (2009) mention that the failure of creating a successful business model leads to failed businesses. Even though many companies use technological tools to provide better services to customers, some disregard the usage of innovative tools of modernity. 
There is a great relationship between using management skills and attaining high revenue for the company. An experienced entrepreneur in dealing with the changing market and environment trends (utilizing their management skills) of the market is more likely to succeed than an entrepreneur who does not have the basic skills to survive in a competitive market (Cassar, 2006). In addition, nine out of ten American businesses have failed due to lack of business and management skills (Megginson et al., 2003). Most of the successful businesses are owned by entrepreneurs who have experience in management skills (Lussier and Robert, 1996).

\subsubsection{Lack of technological innovative business ideas}

A recent study at Telfer School of Management (University of Ottawa) mentions the reasons of the large number of female entrepreneurs in the other industries is because of the lack of technology entrepreneurial strategies (Orser et al., 2012). Christensen (2003) argues that being able to develop products and upgrade the services leads to the creation of a competitive advantage that makes the products of the company attractive to people rather than competing with others who have the same products (Christensen, 2003). Entrepreneurs should be able to change and upgrade their products based on customers' changeable needs and market trends fluctuations (Hite, 2005). It is important to note that continuous innovation is a very important factor to obtain and sustain competitive advantage in the market (Kambil, 2002). According to Stimard et al. (2008), the lack of high technology skills plays a major role in preventing females to set up high technology businesses. "The odds of being in a high-level position are 2.7 times as great for men as for women in technology sectors" (Stimard et al., 2008: p 4).

For a company to maintain success, it requires innovative ideas that are capable of improving the customers' needs with faster and innovative services. When companies fail to offer innovative services, they risk losing their customers for other competitors offering better 
services. Customer needs change significantly, and entrepreneurs should adjust to these challenges (ADB, 2001). Furthermore, it is important for high-technology female entrepreneurs to be aware of technology and market changes because they must stay up to date with them in order to create sustainable competitive advantage. It is challenging to create an accurate business model and strategy that build technological innovative businesses (Teece, 2010). Female entrepreneurs face the challenge to create a product that will effectively serve the customers globally and nationally (Candida et al., 2001). The participation in the global market requires innovative ideas because countries around the world have advanced technologies and companies with long experience of operating on global scale (Alvarez, 1999).

Similarly, successful high-technology female entrepreneurs encourage more females to get a technology engineering education to be ready to set up their own businesses in high technology sector (Gupta et al., 2009). Similarly, innovative businesses attract customers' because people like to deal with efficient modern products and services; this benefits the high technology sector in the short and long run (Katila and Shane, 2005). Figure 5 shows that female entrepreneurs should get the right education and knowledge to deliver high technology products and services. 
Figure 7. Innovation Components

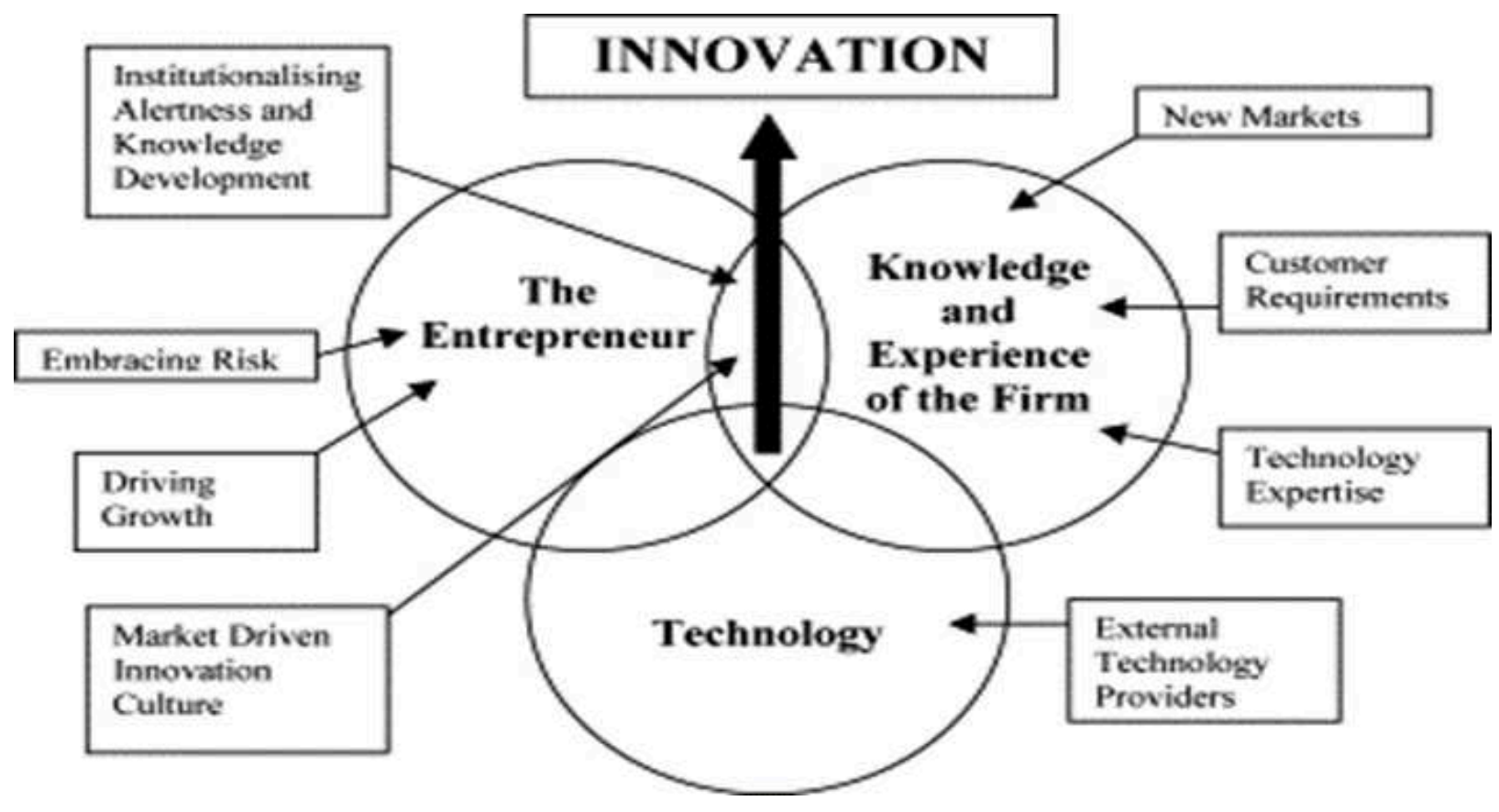

Source: Park, (2005)

As it is shown in figure 7, there are three major components to creating technologically innovative business ideas; they are the combination of the entrepreneur, knowledge and experience of the firm, and technology. The existence of the three factors together in the business process generates new products and solutions innovation. The existence of new markets, customer requirements, technology expertise and external technology providers are the characteristics of the firm's knowledge and experience. Entrepreneurs embrace risk because they are driven with high growth while technology is characterized by the existence of technology external providers. Finally, the innovation is driven by the trends of the market and its requirements and the institutionalization of the market needs alertness and the market knowledge. 


\subsubsection{Overcoming Bad Business Experiences}

One reason that female entrepreneurs may be less likely to establish new technology businesses is that they have previously had bad business experiences. Although having bad experiences teach women how to avoid previous mistakes, this trauma is considered to be a difficult challenge to overcome. A survey carried out by MacDonald (1986) on 519 female entrepreneurs reports that the most important factor that encourages females to own successful businesses is the length of their experience in the investment field. Female entrepreneurs may need mentors to help them overcome bad experiences. It is important to note that the mentorship supports female entrepreneurs to build their ideas and be confident to start new businesses (White House Council, 2012). Many women have had bad business experiences because they did not have good management and business skills, technological ideas and time devotion to business. In a survey, 96\% of respondents mentioned previous work experience as an important factor in being successful in high technology businesses (Wadhwa et al., 2009).

\subsubsection{Lack of Motivation}

Research indicates that the tolerance to risk is the main driver of the motivation to be an entrepreneur (Segal et al., 2005). The non-tolerance to take the risk to invest one's own money and to risk the current job's income (opportunity cost) is because preventing people including females to be motivated to become entrepreneurs (Cassar, 2006). The high cost of starting up a business in high-technology discourages females to do which increases the workers and job seeker number. In the majority of the OECD such as USA, UK, and France the large variations in the start-ups' cost has correlation with the variation in the workers and employment level (Fonseca et al., 2001). In addition, because of their feminine traits, women have less motivating willingness to compete in the global market, so they prefer to start small traditional businesses (Gupta et al., 2009). 
Stereotypical perceptions promote the idea that men have confidence and aggressiveness that allow them to take necessary risks and be successful in high technology business careers (Gupta et al., 2009), whereas females face big pressure about their performance if they want to be successful in their businesses. According to Thompson (1999), the common stereotype is that "entrepreneurs are regarded as businessmen rather than women".

The Canadian economy is driven by large companies that were inherited from the family members. Inherited capital management firms show low growth, low labor Capital ratio, and low R\&D expenditures. This economic phenomenon in Canada is called the "Canadian Disease" (Morck et al., 1998). These firms represent entry barriers to the high-technology entrepreneurship because they affect the sector attractiveness. A real movement from stakeholders all together to support SMEs and women entrepreneurs is important. The lack of information, the lack of funding, and the public sector bureaucracy participate in the lack of motivation (Mathew, 2010).

\subsubsection{Family Obligations}

According to Winn (2004) female entrepreneurs have more responsibilities than male entrepreneurs do because women manage their companies and take care of their household at the same time. The study (ibid.) states that it is difficult for female entrepreneurs to find a balance between both tasks because it is both time and energy consuming. However, women can deal with much more work by showing the ability of dealing with many things at once. As Winn (2004) argues, females tend to do twice as much work than males do in order to prove themselves. Although any harassment can be difficult to overcome, especially when it is gendered harassment, female entrepreneurs find a way to remain determined and move on 
because they have many responsibilities. Therefore, they spend time, efforts, and energy to overcome any barriers they face in their entrepreneurial career.

High-technology female entrepreneurs struggle because they are committed to their demanding jobs as well as being the source of income for their families. Women technology entrepreneurs are caught between managing their businesses constantly and spending quality time with their families and partners. In comparison to other traditional entrepreneurship projects, technology entrepreneurship takes the most time and effort for female entrepreneurs. On the other side, men benefit from their time to work on their businesses while women work fewer hours than them because of their family obligations which affect their possibilities of achieving higher growth (Chay, 1993).

\subsubsection{Higher Education and Industry Liaison}

The role of the higher education institutes is very important in the development of the high-technology sector. Its role ranges from a pure educational and lectures provider, sponsor of high-technology firms through grants and paid research, and technology licencing provider to a spinning-off enterprise creator. These institutions play also the role of the formal and informal advisor for the firms. Relationship between universities and the industry is very important. There are different forms of liaison in this relationship. Firms in the high technology sector are considered as the source of innovation that is altering the mix of the current products, industries and jobs in the economy (Malecki, 1997). The cooperation with educational and research institutions from one part and the high-technology firms from the other part represents an efficient way to use R\&D resources (Bidault and Fischer, 1994; Westhead and Storey, 1995; Håkansson and Hellman, 1984). The development of relationships between the higher education 
institutions and firms, in the high-technology industry, encourages the innovation and production which implies an enhanced level of wealth and more available jobs (Malecki, 1997).

The form of the higher education and industry interlinks can be in different forms such as Science Parks, incubator centres, Higher Education Institutions companies (Westhead and Storey, 1995). For instance, science parks in the UK play a very important role in the commercialization of academic research. Firms located in science parks, incubation centers and other industrial spaces have a high probability to ask for information and seek help from higher education institutions. High-technology start-ups and even existing companies are highly in need of a supportive environment especially from high education institutions and science parks (Lorenzoni and Ornati, 1989). By 1985, Cambridge University was indirectly behind the launching of 261 high technology firms in the Cambridge area (the university area in Cambridge). After the success of the science park experience, many universities became interested to update the technological capabilities of high technology firms in their communities and areas (Westhead and Storey, 1995). At that time, $46 \%$ of high technology firms agreed that they either had direct or indirect R\&D links with higher education institutions (Keeble, 1989).

Universities and higher education institutions turned to knowledge entrepreneurs not only in the form of licencing private firms to use their technologies but also by creating spinning-off commercial enterprises to exploit their researches and technologies (Fisher and AtkinsonGrosjean, 2002). Ventures in the high-technology sector can secure their survival on their own by building networks (Low and MacMillan, 1988). An essential part of the network is the relationships with the higher education institutions that can act as growth vehicles for high technology firms by offering sponsorships through grants, contracts and research (Flynn, 1993). The competition in the high-technology is very difficult and very expensive to encounter. For 
this reason, the relationship with higher education institutions gives a chance to accede to scientific and technological knowledge (Westhead and Storey, 1995).

The Industry-Liaison offices at the Canadian universities are another experience of successful interlinked higher education institutions and industry firms. The importance of the liaison offices rose because when the scientific research importance in the economy increased the need to enhance the scientific research management became a priority for both universities and governments. The Liaison offices as part of the Canadian universities play the role of the scientific research management and commercialization (Fisher and Atkinson-Grosjean, 2002). They occupy the role of the boundary objects between the higher education institutions and the private and the public enterprises (corporate sphere) in the surrounding of higher education institutions in the academic sphere (Star and Griesemer, 1989). The managers of these offices are in charge of doing the boundary work to bridge these two worlds (Fisher, 1993; Gieryn, 1995, 1999; Fuller, 1988).

The higher education institutions have another important role to play, which is, in fact, its fundamental role. The entrepreneurial courses and programs are designed to give the required knowledge for students to be able to fit the industry as entrepreneurs. These programs and courses are not able to give the student the propensity to start an entrepreneurial career if they are not mediated by the entrepreneurs' self-efficacy (Zhao and Seibert, 2005). There are a number of programs in Western countries that have proven their efficiency, such as the Young Achievement Australia (YAA) in 1977 that was an extension the US 1911 Junior Achievement program. The YAA is an enterprise education program that was designated to build the entrepreneurial career desirability. The program covered all the disciplines to help young people and students to get deep knowledge and understanding of the core skills of companies and enterprise skills. 
The higher education institutions are also the manpower provider. Educational institutions prepare the technical and business specialists for the high-technology industry (Zhao and Seibert, 2005). The YAA program gives its participants great opportunities to build knowledge and understanding of the business different aspects such as marketing, accounting, finance, human resources and firm lifecycle. The program was built on four different models representing the different firm lifecycle stages from the foundation, growth and maturity to liquidation of the firm. The program showed big success in changing the propensity of the entrepreneurial desirability in the participants (Peterman and Kennedy, 2003).

\subsubsection{Role of Ecosystems and Keystone Organizations}

Business ecosystems including companies, individuals, academic institutions, and government agencies use the community out-of-the-box tools to generate value for their customers and partners. The keystones, as leaders in the ecosystem, are organizations providing platform for individuals and organizations to build their projects. These projects can be contributory, collaborative, co-creative and characterized by co-option. For example, Lead-toWin is an ecosystem that was created to help high-technology companies in Ottawa region (Bailetti and Hudson, 2009). In other regions of Canada there are, e.g., the Women's Enterprise Centre of British Columbia, the Enterprise Centre of Manitoba, the Alberta Women Entrepreneurs, Paro Centre for Women's Enterprise in Northern Ontario and Réseau des Femmes d'Affaires du Québec (RFAQ). There are similar organizations operating in other parts of the world. Silicon Valley based Women 2.0 Program, Springboard Enterprises, Women and Enterprise in Boston and Asian Women Entrepreneurs are ecosystems operating in the US. European Union's Women Entrepreneurship and Cherie Blair Foundation are operating in Europe (Singer and Dexter, 2011). 
These ecosystems are job creation engines which are built as collaborative and collective organizations dedicated to creating technology ventures and support their growth. The ventures created are usually expected to create at least a certain number of jobs (a minimum of six in the case of Lead-to-Win). The main objective of ecosystem organizations is to support ventures to achieve levels they could not reach if they work on their own. The main objective and performance measurements of these organizations are to increase the diversity of the knowledge jobs and the attraction of the region to investments (Bailetti and Bot, 2013).

\section{Figure 8: Five components of Lead-to-Win services delivered to technology entrepreneurs}

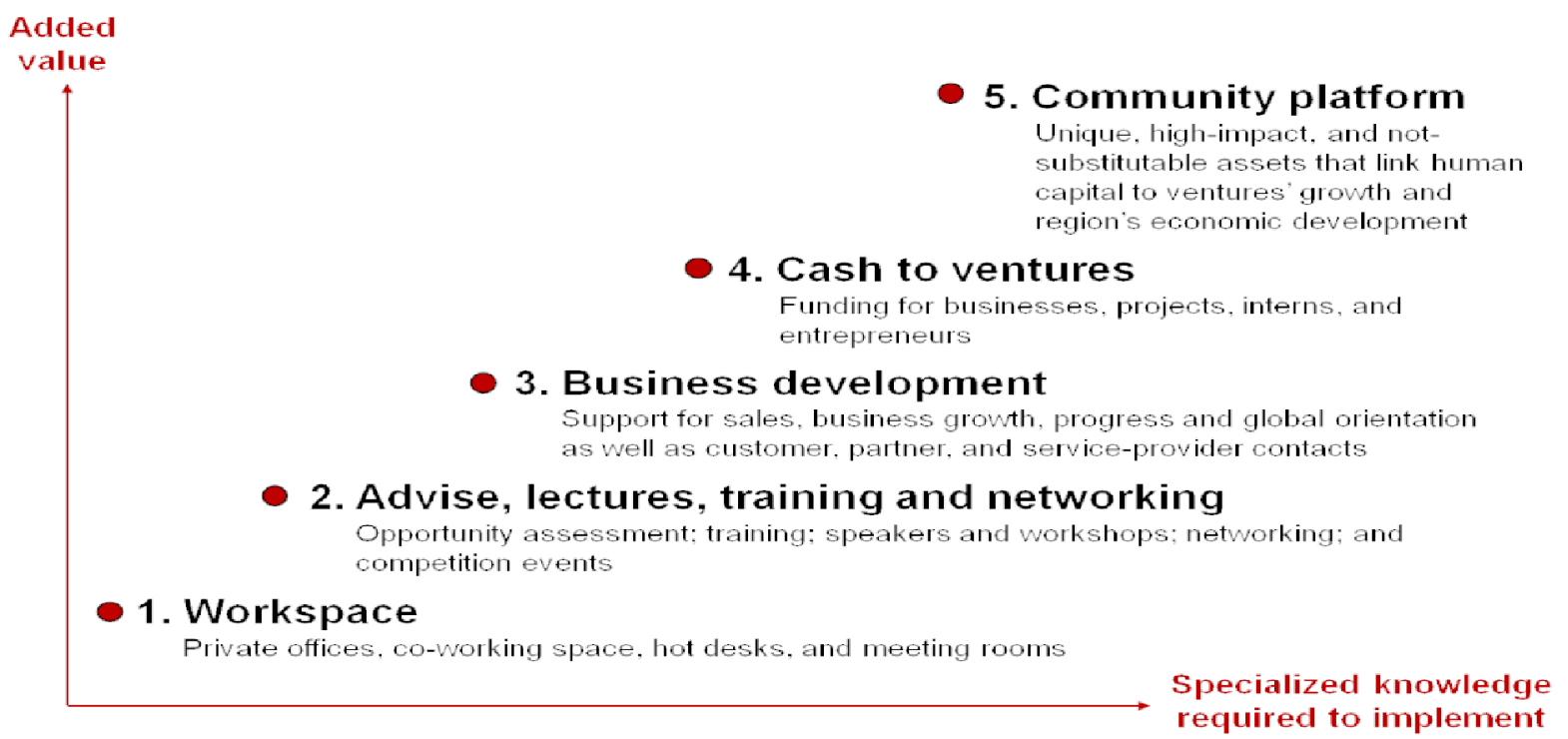

Source: (Bailetti and Bot, 2013)

Figure 8 represents the five different missions of the ecosystem in general and Lead-toWin specifically. The first service Lead-to-Win delivers to its members is helping them by providing private offices, co-working offices and workplaces to perform their activities. Lead-toWin organizes lectures, trainings, and public talks to help its members enhance their managerial and technological skills as well as networking events to allow entrepreneurs to meet and build 
business networks. Third, these organizations provide business development services through networking which enables entrepreneurs to grow their sales, build global orientation and make contacts in the industry. Fourth, ecosystems help entrepreneurs by providing cash and grants. Finally, they provide community platform which consists of assets linking human capital with the growth of ventures (Bailetti and Bot, 2013).

Thus, every company is part of one or different ecosystems. On the other side, every ecosystem consists of companies and individuals cooperating together to solve problems of members of the ecosystem. According to Bailetti and Bot (2013), entrepreneurial ecosystems can provide workplace, advice lectures, trainings and networking, business development, cash ventures, and community platform services. Companies that neglect the importance of such ecosystems have higher propensity to fail. Entrepreneurs, who fail to understand their ecosystem's functioning way, operate at a significant disadvantage. Small high-technology companies perform their activities in a better way if they use the resources offered by their ecosystems to add value to their customers, partners and different stakeholders. Properly functioning ecosystems allow their members to co-develop common assets, create an offer and sell it in the market. A healthy and well-functioning ecosystem should contain different participants, be attractive to business and be stable and create a differentiated niche in the market. The ecosystem is considered successful when its participants make better revenues when they operate within the ecosystem than when they are out of it (Bailetti, 2010).

As mentioned previously, the ecosystem leaders are called keystone organizations. The size of keystone organizations differentiates; they can be small or large, complex or simple. Their purpose differentiates too; they can be either for-profit-organizations or not-for-profit organizations. However, the most successful keystones are those commercially driven because of 
the economic value added they create. Keystones can be large commercial companies such as Microsoft, small commercial companies such as oDesk, not-for-profit Voluntary decision makers such as Joomla, not-for-profit supplier members such as Eclipse, and not-for-profit customer members such as Lead-to-Win (Hurley, 2009).

\subsection{Female Technology Entrepreneurs' Coping Strategies}

Solutions to the high-technology entrepreneurs who are starting up new businesses should be innovative to fit this vicious sector. The literature on entrepreneurs' coping strategies seems to be divided into two sides. A part of the literature has focused on the high-technology start-up entrepreneurs in general, whereas the other part has focused on the female entrepreneurs in general. To help high-technology female entrepreneurs, this literature review focuses on strategies coming from the inside of the start-up while it also suggests strategies are coming from the environment. The knowledge is the most important aspect in high-technology entrepreneurial context. It is not only technical because research shows that the technically innovative ideas did not save the start-up from going out of business (Berry, 1998). Entrepreneurs with only technical knowledge may hold back the growth of their businesses and put the continuity of the business in danger because of their lack of strategic awareness (Berry, 1998).

Furthermore, the business and management knowledge is not enough because it does not create a competitive advantage in the market (Christensen, 2003). In the contemporary business context, it is very important to estimate the importance of alliance strategies. Alliances with suppliers, universities, research institutes and customers are very important to create a radical, innovative performance and maintain competitive advantages (Neyens et al., 2010). 
Also, strategies are required to boost high-technology female entrepreneurs' number in the Canadian economy. The government and the institutions must make efforts to help and encourage females to embrace a high technological, entrepreneurial career. These efforts can be in different forms including events' organization, inviting women to make presentations and show women business models who have been successful in the field to convince other females to start their companies in the sector of high technology. Moreover, the establishment of hightechnology annual women's business award is another strategy. Furthermore, they should make sure that as many females as possible receive the communication and publication documents concerning high technology female entrepreneurs (Kirkwood and Walton, 2010). They also have to create sectorial initiatives to help women by funding some projects or creating alliances to help them grow (Neyens et al., 2010).

Table 4: Summary of Female and Technology Businesses Challenges

\begin{tabular}{|l|l|l|}
\hline Stream & Key highlights of the stream & Key references \\
\hline Opportunity Recognition & Most of high-technology female entrepreneurs fail & Christensen (2003), \\
(Lack of technological & to see opportunities because they lack technology & Hite (2009), Kambil \\
innovative business ideas, & knowledge and/or they do not have connections to & (2002), Hanson and \\
Insufficient business & be informed on what is needed & Blake (2009), Renzulli \\
Network) & et al. (2000), Green \\
Impractical Education & Most high-technology female entrepreneurs have & Gupta et al., (2009), \\
(Business and & impractical post-secondary education to start up & Arai (1997), \\
Management skills, Lack & their companies. Also good education motivates & Kamalanabhan (2000), \\
\hline
\end{tabular}




\begin{tabular}{|c|c|c|}
\hline of Motivation) & female entrepreneurs and gives them incentives) & $\begin{array}{l}\text { Segal et al. (2005), } \\
\text { Cassar (2006), Fonseka } \\
\text { et al. (2001). }\end{array}$ \\
\hline $\begin{array}{l}\text { Personal Commitments } \\
\text { (Family obligations, Risk } \\
\text { to Promise) }\end{array}$ & $\begin{array}{l}\text { In general, high-technology female entrepreneurs } \\
\text { find it difficult to balance their personal } \\
\text { commitments (family obligations) and their work, } \\
\text { it is also hard for them to make external } \\
\text { commitments (Risk to promise) }\end{array}$ & $\begin{array}{l}\text { Winn (2004), Chay } \\
\text { (1993), Kortum and } \\
\text { Lerner (2000). }\end{array}$ \\
\hline Entrepreneurial Support & Generally, obtaining funding, from companies & MacDonald (1986), \\
\hline Financial Support, & $\begin{array}{l}\text { Who give grants, is difficult for female high } \\
\text { technology entrepreneurs because of the negative }\end{array}$ & $\begin{array}{l}\text { Wadhwa et al. (2009). } \\
\text { Brush et al. (2002), }\end{array}$ \\
\hline $\begin{array}{l}\text { Overcoming Bad Business } \\
\text { Experiences) }\end{array}$ & $\begin{array}{l}\text { stereotype that they cannot handle large amounts } \\
\text { of money. Also, overcoming bad business } \\
\text { experiences passes through entrepreneurial support } \\
\text { from other entrepreneurs and organization. }\end{array}$ & $\begin{array}{l}\text { Kamaruzzaman et al. } \\
\text { (2008), Headd (2003), } \\
\text { Verheul and Turik } \\
(2000) \text {. }\end{array}$ \\
\hline
\end{tabular}

Figure 6 summarizes the different challenges faced by female high-technology entrepreneurs operating in Canada as found in the literature. Based on the literature review, there seems to be eight major challenges for female high-technology entrepreneurs. These challenges are the lack of technological innovative ideas, lack of business and management skills, lack of financial support, family obligations, lack of motivation, lack of sufficient business network, risk to promise, and overcoming bad business experiences. 
Figure 9: Challenges Faced by High-technology Female Entrepreneurs

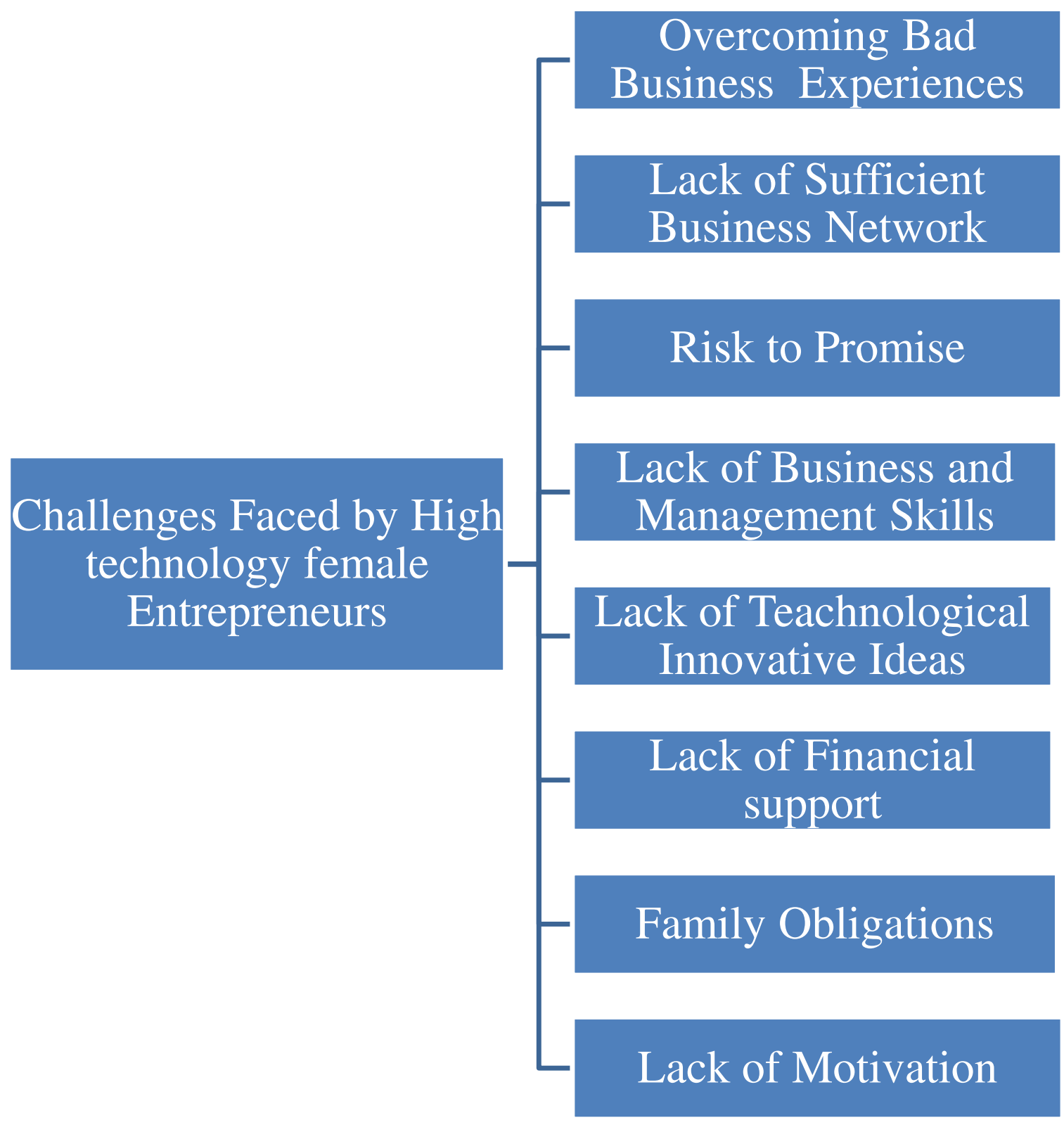




\section{Chapter 3: Methodology}

This chapter explains the methodology used in this research. The first section includes a brief research design explanation. The second section provides information on the sample and sampling method. The third section explains the data collection process and the analysis of the data. In this study, methodology framework was developed based on literature review and interviews were made with five high-technology female entrepreneurs in Ottawa.

First, the research investigates the main challenges facing female entrepreneurs who are operating in Canada. Second, it provides procedures and methods used to complete this research. The results of this research help to develop strategies for high-technology female entrepreneurs to overcome these barriers. The increase in the number of female entrepreneurs promotes the innovation and increases the creation of value added in the Canadian economy.

\subsection{Research Problem/Question}

In general, the number of high-technology female entrepreneurs is small. The research aims to explore the different challenges facing high-technology female entrepreneurs when they start-up high technology businesses and the different strategies to overcome these barriers.

\subsection{Theoretical Framework}

The theoretical framework is an attempt to discover challenges facing high technology female entrepreneurs using a cross literature review. Finding the challenges facing high technology female entrepreneurs is difficult because previous researches approach female entrepreneurs' challenges rather than high technology female entrepreneurs' challenges and they tend to focus on one specific challenge rather than approaching different challenges in one paper. This paper uses cross literature review on a large number of research papers to investigate the 
various challenges that have been previously discussed. These challenges were never discussed together in the same research. The cross literature review, as done by different previous researches such as Ibrahim and Soufani (2002), aims to gather all high technology female entrepreneurs' challenges in one research. The research divides the challenges into opportunity recognition, impractical education, personal commitments and entrepreneurial supports challenges. The second part of the theoretical framework presents the data collection and analysis process. Data analysis is used to investigate the importance of every challenge for hightechnology female entrepreneurs to explore if different entrepreneurs face the same challenges.

\subsection{Literature review}

By reviewing the literature; the research explored the different challenges faced by female entrepreneurs in Canada to startup their own business, and applied them to hightechnology female entrepreneurs. Many research papers talked about these challenges, but none of them studied all these challenges in the same paper, and none of them investigated high technology female entrepreneurs' specific challenges. Previous researches enable collection of all challenges and the separation of these challenges into opportunity recognition, impractical education, personal commitments, and entrepreneurial supports challenges' categories.

\subsection{Data Collection}

A face to face interview was designed to confirm if high-technology female entrepreneurs share the same challenges and their importance in reality. Face-to-face interview method was used because of the limited empirical research on high-technology female entrepreneurial difficulties and barriers; it was anticipated to bring about rich descriptions of these challenges. 


\subsubsection{Sample and sampling techniques}

The sample initially included 16 high-technology female entrepreneurs from the Lead-toWin for Women organization, which is located in Ottawa. It was first established to help female entrepreneurs overcome their challenges (LTWW, 2013). These females already started their high-technology businesses. The invitation to participate in the research was sent after applying and getting an approval from the Research Ethics Protocol at Carleton University. Invitations were sent to each interviewee by email. A meeting with every entrepreneur was set up in TIM lab at Carleton University. A total of 5 out of the 16 contacted high technology female entrepreneurs responded positively to the invitation and were interviewed. The others declined the interview because they were very busy working on their companies and did not have time for a meeting. On the other hand, Eisenhardt (1989) suggests the best range for the number of cases to be between four and ten; thus, five cases is feasible. The interviews with each entrepreneur lasted around an hour.

The fields of operations of every interviewed entrepreneur are presented in Table 5. All the interviewed women entrepreneurs operate within the high-technology sector (computer and mobile applications). Only one of the entrepreneurs is not married. All the interviewed entrepreneurs are self-financed (love money from household) except one who gained equity by helping in the development. All of the interviewees were between 27 and 40 years old. Thus, the study does not need to control for the age, industry or income since the interviewees have fairly similar background and resources. 
Table 5: Interviewed Female Entrepreneurs

\begin{tabular}{|l|l|l|}
\hline Company & High technology business & Type of service/products \\
\hline 1 & Yes & Online store \\
\hline 2 & Yes & $\begin{array}{l}\text { Consulting services (data and statistics } \\
\text { online processing application) }\end{array}$ \\
\hline 3 & Yes & Online food ordering for different \\
& & restaurants \\
\hline 4 & Yes & Online Store document \\
\hline 5 & Yes & Productivity tool (online digning and transferring application) \\
\hline
\end{tabular}

All of the interviewed women already owned their high-technology companies. Two of the companies provide online consulting services dealing directly with customer concerns. One company provides software development service. The third interviewee owns an innovative health applications company (online store for visual stress solutions). Another participant created a mobile app for online food orders to avoid lineups. Lastly, one interviewee works on improving business productivity by providing an online document signing service. This service eliminates the need to print, sign, scan and resend or fax documents by allowing users to easily sign documents with a mouse or stylus. The recorded interviews have been transcribed in order to identify the key challenges faced by high-technology female entrepreneurs in Canada.

Face-to-face recorded interviews, each of which lasted about one hour, covered business operations, background, financing and businesswomen education information. The qualitative 
information is gleaned, answer by answer, by organizing all the similar answers and different answers together to identify the portion of high-technology female entrepreneurs who agree or disagree on the importance of each factor. This gives an approximate percentage on the number of cases supporting or rejecting the challenges found in the literature (Belcourt, 1990).

\subsection{Data Analysis}

Data analysis includes examination, classification, and developing a theoretical framework. The theoretical framework is created based on previous literature analysis of the data collected. After finding the challenges, the research proceeds to investigate if these challenges are important for female entrepreneurs, as well as their categories.

\subsection{Time Period of the Research}

Work on this research began in August 2012 by presenting the topic to the Carleton University's TIM program committee. A literature review was completed by January 2013. Afterwards, the face to face interview was designed, approved by September 2013. The questionnaire was reviewed and approved by Carleton University's ethics department. It consists of 44 open-ended questions divided into four parts. The first part consists of seven questions asking about the entrepreneur's background, business, and amount of daily time spent at work. The second part covers questions about internal and external resources supporting female entrepreneurship including education, mentor, and financial support. The last part addresses the challenges of high-technology female entrepreneurs. Interviews were recorded to highlight the key points related to the research. After that, the interviews were written down for analysis. Interviews were finished by August 2013. The sample used was selected from Ottawa's hightechnology female entrepreneur population (members of Lead-to-Win for Women). 


\subsection{Research Design}

The research design provides various deliverables including:

1. The different challenges faced by Canadian female entrepreneurs.

2. Confirming the importance of these challenges from high-technology female entrepreneurs' point of view.

3. Grouping the challenges into four different categories (opportunity recognition, impractical education, entrepreneurial support, and personal commitments).

4. Recommended strategies to overcome entrepreneurial start-up challenges.

\subsection{Unit of analysis}

The unit of analysis is perceived problems and challenges to female technology entrepreneurship.

\subsection{Research method}

The research method is based on seven steps containing the theory's building process from the case study research done by Eisenhardt (1989). "Getting Started" is the first step in the research method. It identifies the research question applied on a real-life issue. The research investigates the issue behind the underrepresentation of females in high technology sector entrepreneurs. "Selecting Cases" is the second step which includes the specific group of high technology female entrepreneurs in Canada. The third step is "Collecting Data". It is based on one-on-one interviews with five high technology female entrepreneurs. "Entering the Field" is the fourth step. It is done by audio recording the interviews as well as writing them in the documentation (tangible source of support). 
"Analyzing Data" provides the results of the face-to-face interviews. "Shaping Hypotheses" compares the results of the interviews with the existing theories found in previous literature (consistency with the literature). "Build Models from Analyzed Data" compares two distinct models representing both theory and practice. The first model lays out the theories taken from the literature review. The second model presents the results of the one-on-one interviews (found with both methods gleaning propositions and data coding). The final step, "Reaching Closure" focuses on the main challenges and provides suitable solutions.

\subsection{Research Steps}

Research steps are presented in Figure 10, which shows them in a chronological order (getting started, selecting a sample, collecting data, analysing data, and building frameworks).

\section{Figure 10: Research Steps}

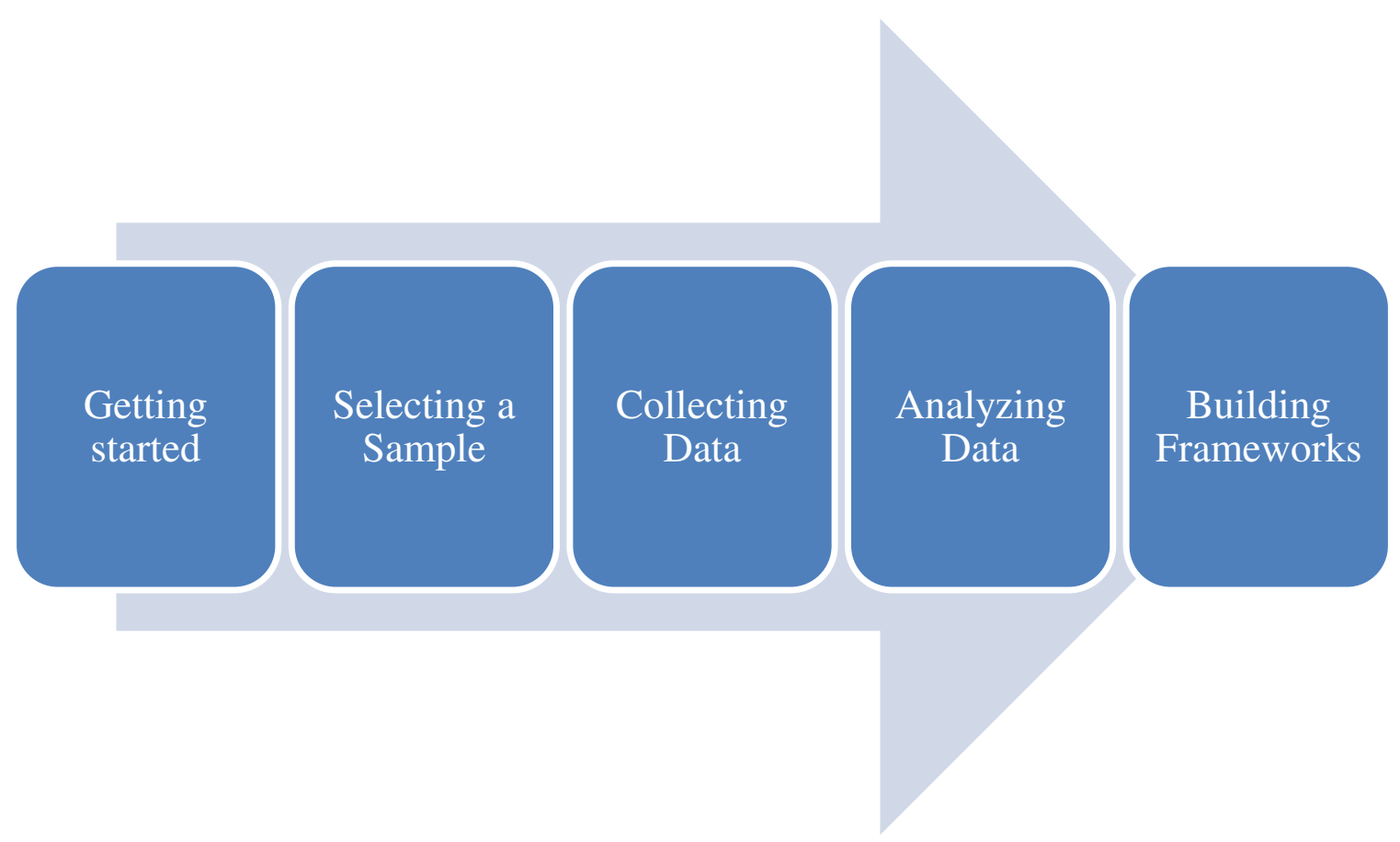




\section{a. "Getting Started"}

This step introduces the research questions of this thesis which are:

A. What are the challenges that are faced by women technology entrepreneurs?

B. Do high technology female entrepreneurs agree with the challenges mentioned in the literature review?

C. How can these challenges be solved?

\section{b. "Selecting Cases"}

Interviewed high-technology female entrepreneurs were selected among Lead-To-Win for Women (LTWW) members. The organization has many female members who already started up their high-technology businesses in Ottawa. Initially, the sample of this research contained 16 high-technology female entrepreneurs from the LTWW. They were selected because they were anticipated to have good knowledge and experience in creating high-technology businesses. A final sample of five high-technology female entrepreneurs was selected because some of the selected entrepreneurs were busy or did not reply to the interview request. Face to face interview method was chosen because it gives accurate results of what these challenges are (because the researcher can ask further questions if the answer is not clear).

These selected participants are appropriate because they have their own businesses in technologically innovative fields, and they face many challenges to remain in business. Participants must exactly match the purpose of the research (they must be female entrepreneurs from a high-technology industry). In addition, secondary data was collected from different sources such as Kaffin website and other websites that provide recent data on high-technology female entrepreneurs. 


\section{c. "Collecting Data"}

Face to face interviews were conducted with five high-technology female entrepreneurs from Ottawa. Additionally, this research has used various secondary data including brochures, articles in practitioner magazines, content on relevant websites and other relevant sources. No comparison to men was used since women are seen to have some unique challenges compared to male entrepreneurs. Recorded interviews lasted between 30 to 60 minutes and in some cases the interview went longer than one hour. The answers were written down to make sure all the information needed is available. The ambiance of the interview was the interaction and the further questions asked if the answers were not clear. This enriched the study because of the different challenges faced by every entrepreneur. After writing down all the interviews, similar answers were collected together to count how many female high-technology entrepreneurs agree or disagree on each challenge.

\section{d. "Analyzing Data"}

The first step is to clean the information in order to identify entrepreneurs who confirm or disagree with the challenges derived from the literature review. The analysis of the collected data includes examination and classification framework development. The examination of the framework is created based on the previous literature on the high technology female start-ups issues. Then the classification framework is based on the interviews coding and classification. The analysis phase includes identifying and coding different problems and challenges for the purposes of framework building. In addition, coding enables counting the frequency of occurrences of challenges and problems in the interviews. This was deemed a viable method, because comparable studies have drawn on small sample sizes (e.g., Siddiqui 2008). The interviews made use of open ended questions even though the structure of the interviews 
remained the same, thus an interviewee's notion on a specific challenge was not pushed nor influenced in any way. Any mentioned challenges were seen to represent the significance or importance of the specific challenge to the entrepreneurs. By counting the occurrences it was seen that the researcher is able to capture this importance and rank the objects.

\section{e. "Shaping Assumptions"}

Based on the examination and classification frameworks an explanative assumption is built and tested to create a theoretical framework. Different assumptions were adopted over the study (Strauss, 1987). The first of them was that the family obligations would prevent female entrepreneurs from accomplishing success. The second assumption for the under-representation of female technology entrepreneurs is the imposed syndrome (sexist vision) because people cooperate less with female partners.

\section{f. "Build framework from Analyzed Data"}

Two frameworks or models have been made based on both theory and collected data. The first framework presents challenges (gathered from the literature) preventing female entrepreneurs from starting up high technology businesses in one paper. The second framework exposes the research value added as it investigates the importance of the challenges mentioned in the literature from the interviews with high technology female entrepreneurs. The research recommends strategies for both existing and future female high-technology startups to overcome their challenges and difficulties.

\section{g. "Reaching Closure"}

The project ends with the final stage by covering all research questions. Information derived from the research applies to high-technology female entrepreneur in general. The results acknowledge decision makers about the way to help female entrepreneurs start and sustain their 
high-technology sector's business. The paper provides strategies for high-technology female entrepreneurs to help them overcome their challenges.

\section{h. Challenges Faced by High-technology Female Entrepreneurs}

To organize the eight factors identified in the literature; the paper groups the challenges into four main categories. Figure 8 shows the Opportunity Recognition category. It includes the Lack of technologically innovative business ideas, and the Lack of sufficient business network challenges. The second category is the Impractical Education that is presented in Figure 11. It includes the Lack of Business and Management Skills, and the Lack of motivation. The third category presented in Figure 10 is the Entrepreneurial Support Network. It includes the Lack of Financial Support, and Overcoming Bad Business Experiences. Figure 11 presents the Personal commitments category. It includes Family obligations and Risk to Promise challenges.

Figure 11: Opportunity Recognition Challenges Facing High Technology Female

\section{Entrepreneurs}

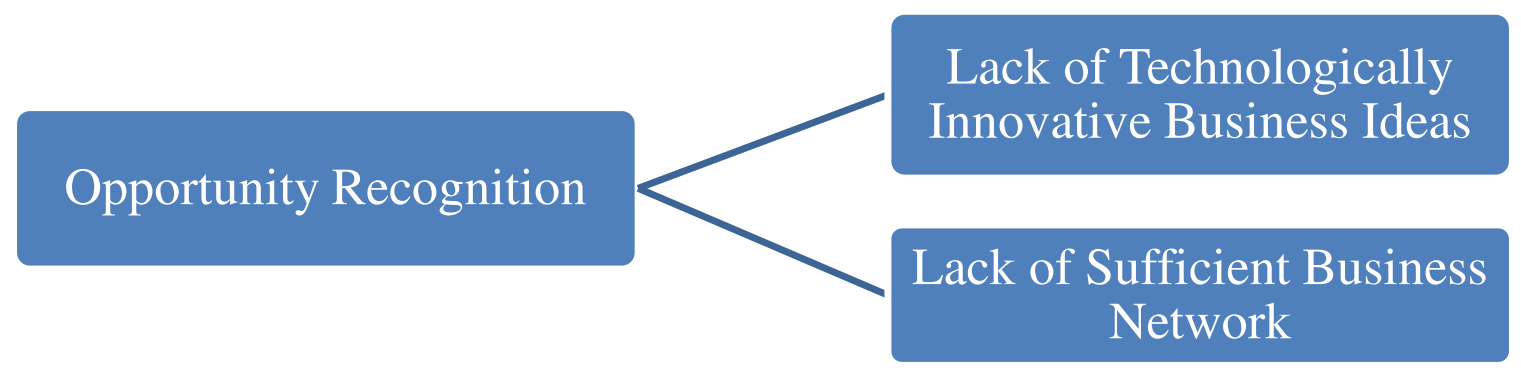


Opportunity Recognition includes the Lack of Technologically Innovative Business Ideas and the Lack of Sufficient Business Network. These challenges are obstacles to finding opportunities in the market.

Figure 12: Impractical Education Challenges faced by High-technology Female Entrepreneurs

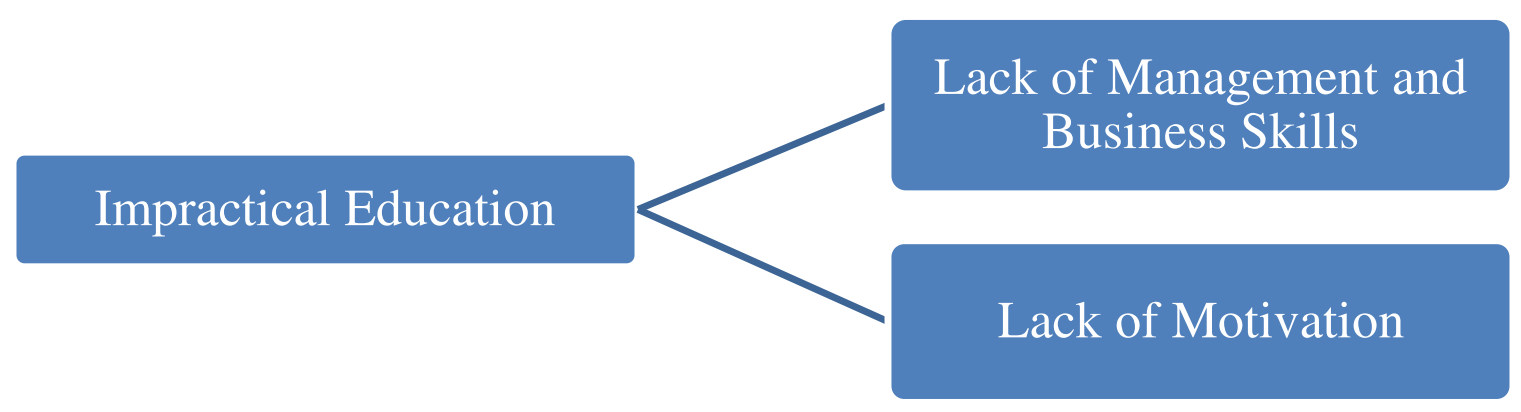

Figure 8 illustrates that the Impractical Education Challenges includes two factors (Lack of management and business skills and Lack of Motivation). The practical education enables the entrepreneur to manage her company to grow. It also motivates women to start up their businesses. 


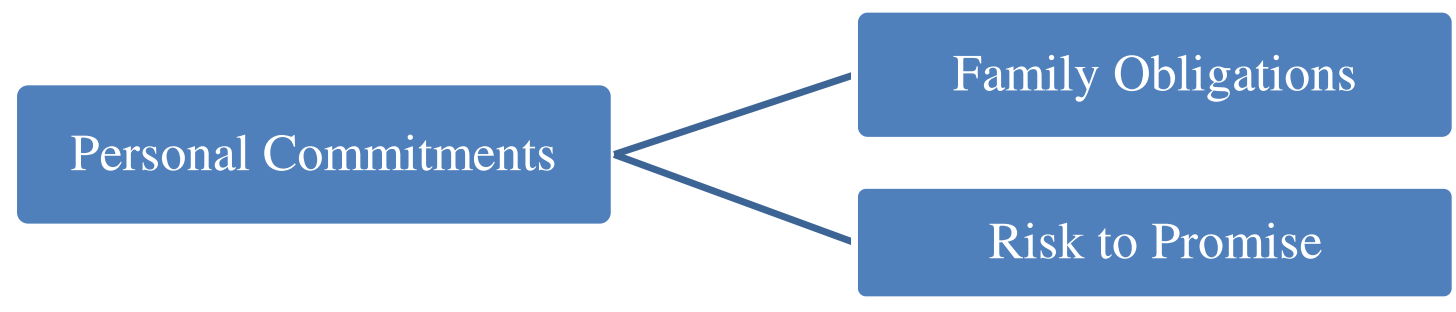

Figure 13 represents the "Personal challenges" category. It includes family obligations the risk to promise challenges.

Figure 10: Entrepreneurial Support Network Challenges

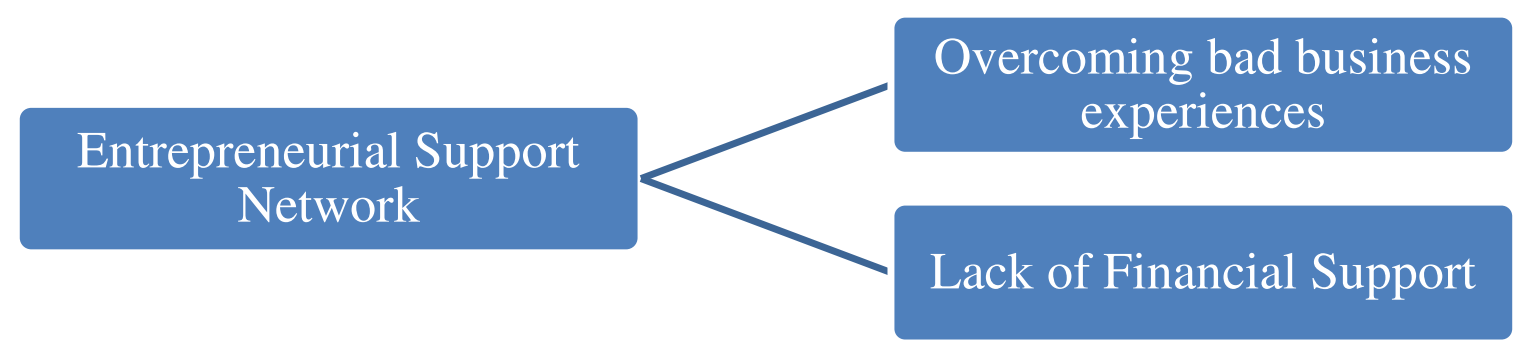

Entrepreneurial Support Network category, as presented in Figure 10, includes the lack of financial support and overcoming bad business experiences. 


\section{Chapter 4: Findings}

This chapter presents, discusses and summarizes findings from the interviews.

\subsection{Results}

\subsubsection{Opportunity Recognition}

Opportunity recognition consists of challenges preventing high-technology female entrepreneurs from having chance to acquire business opportunities and creating a viable market share.

\subsubsection{Lack of Technologically Innovative Business Ideas}

Lack of Technologically Innovative Business ideas is caused by the lack of education in the field of technology. The technological idea is a part of the innovation generation process. The innovation is the development of a new product to solve existing problems and help in the decision-making process (Utterback, 1971; Pinchot, 1985). Interviewee \#1 said: "There are many complicated things requiring software program to be solved. Female may not have knowledge on software programs because they do not enroll in computer program".

The innovation process consists of generating the idea, definition of the project, problemsolving, design and development of the product, and sales (marketing) (Baker and McTavish, 1976; Rothwell and Robertson, 1973); “when you start up you need to go through, I don't know, production, tips, prototype, things like that can be very time consuming, it takes lots of monetary investment from the person, usually what they do when they start up but for someone with software skills it's just very creative and you feel like you just change the world just by spending few working hours at night" (Interviewee 1). Interviewed high-technology entrepreneurs agreed on the importance of this factor in both recognizing possible opportunities and developing them. 
One of the entrepreneurs said: "there are so many industries that we don't really get into because maybe our culture of software development does not about that industry" (Interviewee 1).

Another entrepreneur said that she started the business because she saw an opportunity and because her children needed it: "The influence was that there is no availability of products and services and my children required it, so I started to create a business to meet the need" (Interviewee 2). One problem that entrepreneurs mentioned is that one cannot acquire all kinds of expertise in technology knowledge and that is why they tend to get partners and team members, "so yeah definitely it's really good to have a team and that what I am doing" (Interviewee 1). These partners have expertise that helps the entrepreneur finish the development of the program: "We have been lucky, we have been working with University of Ottawa Dr. Carlisle Adams, he is a security expert and he was an In Trust architect before he became a professor. We are working together to improve the security" (Interviewee 4). "I own technology business based on previous experiences in high tech sectors. I launched my own company with 2 partners who were working with me on business. I studied masters in computer since. Partners are very important to start up high tech sector" (Interviewee 3).

"In my opinion, having innovative business ideas is absolutely essential to being successful in creating high-tech businesses. It is very important to be creative and have something unique that others are not offering so that you can be successful. You need to keep up with the trends in your field and keep your eyes open for the technological changes overall. The innovative ideas and knowledge are a must in order to have the lead because being "average" really will not give you success in such a dynamic field" (Interviewee 5). All five interviewed entrepreneurs agreed that the Lack of Technological Innovative Ideas is very important for any female high-technology entrepreneur. 


\subsubsection{Lack of Sufficient Business Network}

The Lack of Sufficient Business Network is a reason for not recognizing the opportunities of business because those with good connection get information about the needs of companies and organizations: "There was one guy from IBM who approached me to be his business partner" (interviewee 1). The connection in the industry helps to know the opportunities as well as introducing one's product; "The more people you can build the trust and positive relationship with the better it is for you to be able to get help and support when you need it. The saying "it's not what you know but who you know" couldn't be more accurate, in my opinion" (Interviewee 3). Women in the industry suffer from their limited connections. The support of institutions is very important for them.

Connections with stakeholders and in the industry help diminish all the challenges facing female entrepreneurs: "At that point we decided to approach the government for help. I called my IRAP (Industrial Research Assistance Program). After few days my IRAP-ITA called me (IRAPIndustrial Technical Advisor). I don't feel lonely ever since. So, my IRAP-ITA brought me to Lead-To-Win-for-Women that is led by professor Tony Bailetti from Carleton University. Tony introduced me to the network, after that I have been introduced to Ontario Centre of Excellence and I got so much support from all around and for me I just keep going to create jobs and make revenue" (Interviewee 4).

Moreover, "the Canadian society supports female to start-up and it does not differentiate between men and women. Employment development Canada offers the OSAP (Ontario Student Assistance Program) and second program that helps is Lead to win program. I do not have a mentor yet but I will go back to Invest Ottawa to find a business partner" (Interviewee 2). Consequently, Interviewee 5 explained: "Then we started a prototype (proof of concept). At that point we decided to approach the government for help. I called my IRAP (Industrial Research 
Assistance Program). After few days my IRAP-ITA called me (IRAP-Industrial Technical Advisor). I don't feel lonely ever since. So, my IRAP-ITA brought me to Lead-To-Win-forWomen that is led by professor Tony Bailetti from Carleton University (124). Tony introduced me to the network, after that I have been introduced to Ontario Centre of Excellence and I got so much support from all around and for me I just keep going to create jobs and make revenue".

All the interviewed entrepreneurs stated the importance of entrepreneurial support organizations and the ecosystems for the company. Organizations and academic programs help female entrepreneurs and serve as mediators between entrepreneurs and investors and entrepreneurial support organizations and institutions. They also stated that female entrepreneurial support and the government agencies have been supportive to them.

\subsubsection{Impractical Education}

Education plays a pivotal role in all entrepreneurial aspects. The practical education enables high technology female entrepreneurs to make a growth and find opportunities to be motivated.

\section{a. Lack of Business and Management Skills}

The knowledge in business and management enables female entrepreneurs to design their strategies to manage their businesses and market their products "Yes, the whole marketing and business development what I have to develop my market and develop my channels preparing promotion materials" (Interviewee 2). The lack of these skills makes the company bounded and limits its growth and eventually drives it out of business; "Females entering the high-tech sector definitely struggle if they don't have business and management skills" (Interviewee 3). However, 
there are ways to bridge this lack using entrepreneurial aid programs such as Lead-To-Win for Women and the TIM program: "Lead-to-Win program provides information on how to start up high tech companies. Marketing solutions for problems are very useful by doing presentation and discuss your ideas with others" (Interviewee 3).

Providing short sessions and consultation for female entrepreneurs is a key role of these organizations and programs. Interviewee 1 agrees on the importance of management and business skills but she emphasizes that if the female high technology has technology knowledge the business and management skills can be acquired. "Management and business courses are affecting women to start up however the main issue is lack of high tech degrees rather than business or management" (Interviewee 1).

"Females entering the high-tech sector definitely struggle if they don't have business and management skills. This is a major challenge for females entering the field. It is important to attend a competitive, up to date and supportive post-secondary institution to gain the knowledge you need for the business world. Since the business world is constantly changing, you need to be on top of your education in this field to be aware of all the current trends" (Interviewee 4).

Interviewee 5 was also helped by Lead-to-Win for Women in her marketing and business development. All the entrepreneurs agreed on the importance of business and management knowledge but after the knowledge in technology, except those who have online stores and who said that it is very important for them. Thus, all of them agreed on the importance of business and management and 2 out five said that the knowledge of business and management skills is of great importance. 


\section{b. Lack of Motivation}

The practical education enables females to find the opportunity and acquire the requirements to start a business. When women do not have enough education in business and management they do not have leadership skills and enough information about risk evaluation and planning to start: "I think many women when they have creative ideas; a lot of the times, it is when they are working for someone else, and they would rather not take the risk to go out on their own so they would rather be working behind someone else just for security and other reasons, but they just don't have the audacity, and they do not see themselves in leadership" (Interviewee 1).

Motivation is hard to be gained especially after a bad experience. However, practical education enables female entrepreneurs to see opportunities and be confident of their success "You will need many motivations after a bad experience so you can keep going! Again, a strong support network will help you to stay motivated at the worst of times and in general if you became interested in the first place, I think you have the motivation to do well" (Interviewee 3). Also, the environment of the person plays a key role in motivating female entrepreneurs (stories of success other women is inspiring); "I listen to pop music a lot! Lady Gaga is inspiring for me because she is a creative person in the art, and I'm a creative person in technology. So, I need a creative mind, it's a web application, it has to be practical, simple and beautiful" (Interviewee 4).

\subsubsection{Lack of Entrepreneurial Support}

Entrepreneurial support network is important for both male and female entrepreneurs in all sectors. The role of this network is to help find funding and encourage female entrepreneurs to start their businesses "have a mentor yeah but I will be going back to Invest Ottawa to find a 
business partner" (Interviewee 2). "The saying "it's not what you know but who you know" couldn't be more accurate, in my opinion" (Interviewee 3). Female entrepreneurs are struggling to get help because they do not have enough support although they come with great ideas.

\section{a. Lack of Financial Support}

Many female entrepreneurs use their personal resources to start their businesses because they do not like to approach funding institutions; "This keeps the challenge cycle going for females because if they don't have the financial support, it is simply unreal to expect they can be successful unless they have enough funds of their own saved up to start up the business" (Interviewee 3). Some female entrepreneurs said that they use internal resources and external resources if they can "I went through OSAP Ontario self-employment benefit program; the second that helped was Lead to Win for Women. I used my own personal funds it was easy because my husband has well-paying salary" (Interviewee 2).

Other females said that they found many resources and were helped by different entrepreneurial support organizations "At that point we decided to approach the government for help. I called my IRAP (Industrial Research Assistance Program). After few days my IRAP-ITA called me (IRAP-Industrial Technical Advisor). I don't feel lonely ever since. So, my IRAP-ITA brought me to "Lead-To-Win-for-Women" that is led by Professor Tony Bailetti from Carleton University. Tony introduced me to the network, after that; I have been introduced to Ontario Centre of Excellence and I got so much support from all around and for me I just keep going to create jobs and make revenue" (Interviewee 4). 


\section{b. Overcoming bad business experiences}

Interviewed female entrepreneurs did not consider this challenge as an important factor “"Overcoming bad business experiences” is of course important in general, but I don't think it's a major challenge for females specifically" (Interviewee 3). Female entrepreneurs said that the way to overcome bad business experiences is to be competent and confident in one's abilities: "I was talking before that I can work anywhere because I am on the top of my technical skills, I made sure I developed them, so knowing that I can work anywhere I want is great" (Interviewee 2).

\subsubsection{Personal Commitments}

Personal commitment challenges consist of family obligations and risk to promise. Family obligations are internal personal commitments and risk to promise is an external commitment made for other people.

\section{a. Family Obligations}

Most of the interviewed female entrepreneurs said that family obligations are important but they are not really challenging especially with the technological advancement and social services given to children and families: "I don't think family obligations are a major barrier in this day and age. We live in a time where both the husband and wife need to work in order to maintain their households and we have good supports such as daycare and babysitters to care for our children" (Interviewee 3). They also said that their families have been supporting them and that was a part of their success.

The time and place flexibility characterizing the sector are the reason because most of them are working from their place; "I have been very lucky because my husband and my son have been always supportive. My son and my husband witnessed every step. I spend time with my 
son especially for his music, he is a violist and he also plays piano, so we go together to concerts" (Interviewee 4). Furthermore, some of the entrepreneurs said that they do not have any family obligations, but they have been always able to balance between their business and their personal commitments.

Interviewee 3 said that she thinks that females push themselves to not balance just to imitate men "I am really grateful that I do not have to do that because I have a night job, yeah I was balancing before but maybe not enough considering how much I was working a lot. So I was spending lot of time reading about things, sleeping, relaxing, talking with friends, I think lot of people forget about balancing. Most of the time women pressure themselves to not want balance even though they do because they want to be hard-core".

\subsection{Risk to Promise}

Interviewees said that Risk to Promise is not an important challenge for female entrepreneurs. "Risk to promise is somewhat of a challenge for female entrepreneurs because it depends on how they can convince the lenders that their business idea and business plan will be successful" (Interviewee 3). Interviewee 2 said "No, I have not faced this problem before". This is because females tend to use other sources and avoid asking investors and institutions for financial support; "Yes, I agree that women prefer to borrow money from friends and relatives to start up their companies but men worry more about their prestige if they borrow money from others" (Interviewee 2). Females state that they generally prefer to borrow money from their relatives, family and friends rather than making personal commitments of payment, which will keep them under pressure.

\subsection{Answers to research questions and deliverables:}

The research questions for this paper were: 
- What are the key challenges faced by high-technology female entrepreneurs?

- What strategies could be offered to decision makers, education practitioners, investors, and high-technology female entrepreneurs to overcome these challenges?

The answer for the first question is that the challenges faced by high-technology female entrepreneurs in Canada are the lack of technological innovative business ideas, lack of sufficient business network, lack of management and business skills, family obligations, lack of motivation, lack of financial support, overcoming bad business experiences and the risk to promise. The interviewed high technology female entrepreneurs said that "overcoming bad business experiences" and "risk to promise" are not really serious challenges.

From this categorization we find that the impractical education, opportunity recognition and entrepreneurial support network challenges are the main categories affecting females' abilities to start up their own high technology businesses. The answers of the entrepreneurs show the importance of these challenges for them. For instance, the necessity of the other challenges is clear from their answers such as: "We have been lucky, we have been working with University of Ottawa Dr. Carlisle Adams, he is a security expert and he was an In Trust architect before he became a professor. We are working together to improve the security" (Interviewee 4).

"Yes the whole marketing and business development what I have to develop my market and develop my channels preparing promotion materials" (Interviewee 2). "I think lot of women when they have creative ideas; a lot of the times it is when they are working for someone else and they would rather not take the risk to go out on their own so they would rather be working behind someone else just for security and other reasons but they just don't have the audacity and they don't see themselves in leadership" (Interviewee 1). "I have a mentor yeah but I will be 
going back to Invest Ottawa to find a business partner" (Interviewee 2), "This keeps the challenge cycle going for females because if they don't have the financial support, it is simply unreal to expect they can be successful unless they have enough funds of their own saved up to start up the business" (Interviewee 3). These citations talk about Lack of Technological Innovative Business Ideas, Lack of Business and management Skills, Lack of motivation, Lack of Entrepreneurial support and Lack of Financial Support respectively.

The Family obligations and the risk to promise are less important. This is clear from the answers. Interviewee 3 said that "I don't think family obligations are a major barrier in this day and age. We live in a time where both the husband and wife need to work in order to maintain their households and we have good supports such as daycare and babysitters to care for our children" and "Risk to promise is somewhat of a challenge for female entrepreneurs because it depends on how they can convince the lenders that their business idea and business plan will be successful" (Interviewee 3). Family Obligations and the Risk to Promise challenges are personal commitments facing high technology female entrepreneurs in Canada. These personal commitments impact high technology female entrepreneurs less than the other challenges do. According to the results, none of the personal commitments was identified as major obstacle by participants. These factors were not identified to be among the top barriers for females entering high technology businesses because they said that they don't really face problems with this side.

\subsection{Summary of the results}

In order to examine the relative importance of the identified problems and challenges, the researcher counted the frequencies these challenges occurred in the interviews. A full summary table is presented in Appendix C. Figure 14 illustrates that the interviewed female technology entrepreneurs perceived the lack of technologically innovative ideas (22\%), the lack of business 
network (21\%, and the lack of business and management skills (17\%) as the three most important challenges facing high-technology female entrepreneurs. Conversely, the lack of motivation (7\%), risk to promise (2\%), and the difficulty of overcoming previous bad business experiences (2\%) were perceived the least important.

Figure 14. Illustration of frequencies of mentioned problems and challenges

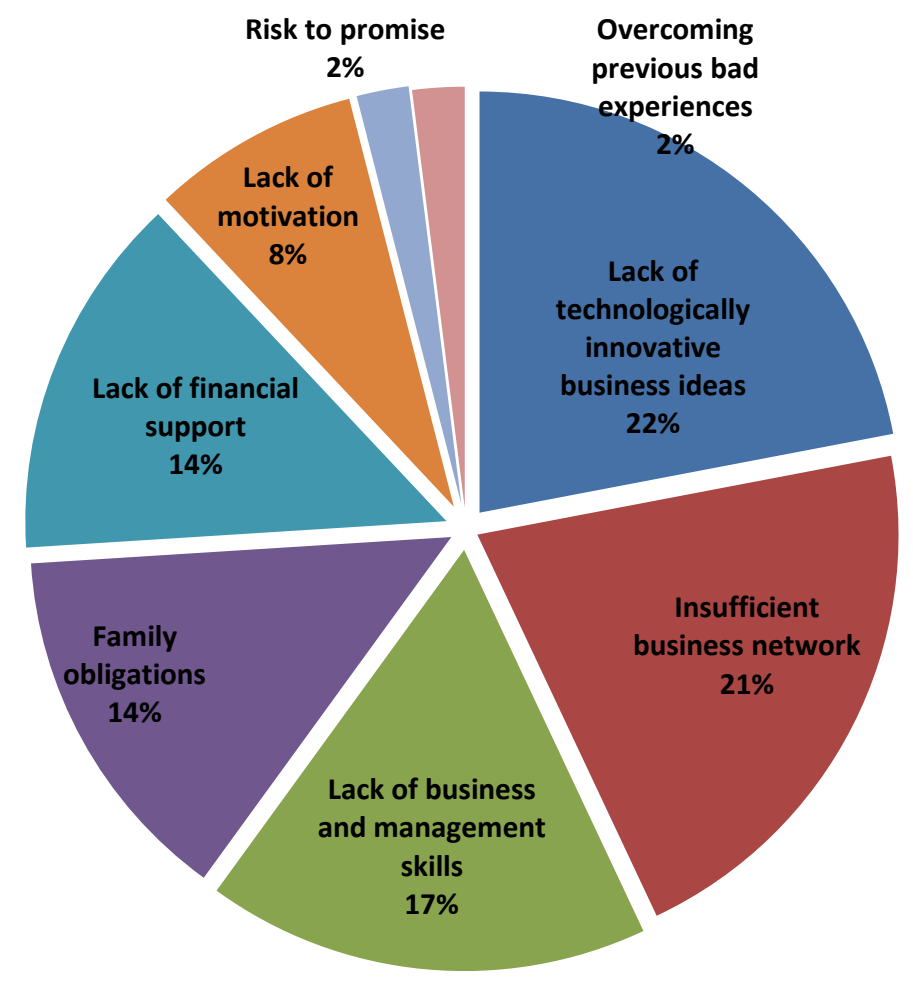

On the basis of these findings, it seems that external challenges to female technology entrepreneurship were perceived more essential than internal factors. External challenges are related directly to operating a business; they are explicit by nature and could be characterized as functional problem to running a business. Conversely, internal factors are more intensively related to launching a start-up; they are implicit by nature, and, thus, can be characterized as psychological barriers to female technology entrepreneurship. 


\section{Chapter 5: Discussion}

This chapter discusses the results of the research as presented in chapter 4 . The discussion is presented in three different sections (discussion of the results, consistency with literature, and the recommended strategies).

\subsection{Discussion}

The purpose of this study was to examine perceived problems and challenges for female technology entrepreneurs to launch and operate their start-ups. The research found that external challenges, such as the lack of business and management skills, seem to be more essential than internal challenges such as family obligations. Moreover, the study found that the lack of technologically innovative business ideas was the most important challenge. Thus, it can be anticipated that he underrepresentation of females in the high-technology fields in Canada is likely due to the low rate of female enrollment in technology and engineering programs at universities across Canada. Females represent only $29 \%$ of the total enrolled students at computer science, $23 \%$ of students registered in engineering programs, and $14 \%$ in math programs (cf. Menzies and Tatroff, 2006).

The difficult financial conditions at early stages of the business prevent entrepreneurs from hiring technology talents to come up with new technological ideas and develop them to create a technological competitive advantage. Also, entrepreneurs state that their main challenge during the first 3 to 5 years is to attract or retain employees (TD economics, 2012). They either develop the technology by themselves because they have the skill to do so, or, they hire developers or find co-founders. An initial assumption that the "family obligations" challenge may be the most important may holds in other traditional sectors but it does not seem to be 
important in technologically innovative sectors where the $R \& D$ is the only way to stay in business and create a sustainable and viable market share. However, the family obligations may become much more important later when the business grows (Cliff, 1998).

The interviewed women technology entrepreneurs said that the lack of sufficient business network is crucial because it allows them to get contracts and be informed on the needs of the market product: "The more people you can build the trust and positive relationship with the better it is for you to be able to get help and support when you need it. The saying "it's not what you know but who you know" couldn't be more accurate, in my opinion" (Interviewee 3). However, Canadian economy is built on large players especially in the high-technology sector (e.g., Bell, Cisco, Rogers, and IBM). The lack of sufficient network with these companies and with key players and stakeholders (decision makers, investors, banks and other institutions) diminishes the opportunities of female entrepreneurs to stay in business or to start-up at all.

Renzulli et al. (2000) and Greene (2003) argue that female entrepreneurs tend to build smaller business networks than their male counterparts. They (ibid.) augment that one possible reason for the lack of sufficient business network is women's emphasis on relationships with peers and family while men put less emphasis on the family. Thus, men have an advantage to create stronger and bigger networks with external actors. Moreover, women may lack the skill of choosing the right beneficial connections. Another possible reason for the limited business network that female entrepreneurs have is the fact that they tend to limit the growth of their companies; $25 \%$ of females who chose the entrepreneurial career are likely to limit the growth of their companies to be able to balance between their work and family commitments (TD economics, 2012). 
Sufficient business network is important because of its effects on the other challenges, including financing and the lack of technological innovative ideas. For instance, an entrepreneur with good connections may get funding that allows hiring people to create and develop new ideas. Connections with business partners, decision makers, and public institutions provide entrepreneurs with relevant information about the problems to solve and the required technology and support for this purpose. This is the reason behind the high anxiety of entrepreneurs towards the lack of sufficient business network. Also, the lack business network is more stressful for female entrepreneurs as it prevents them from acquiring funds and getting information and business opportunities to build up their companies and develop their ideas. A sufficient business network makes the funds' acquiring process easier compared to entrepreneurs going by themselves through the normal procedures.

The lack of business and management skills seems to be among the most important challenges facing high-technology female entrepreneurs because it guarantees the good management of the company's resources and its growth; "Females entering the high-tech sector definitely struggle if they don't have business and management skills" (Interviewee 3). This is because the use of business theories in the business management operations is critical for the business growth and sustainability. The management skills give the ability to market the business in both the local and international market. This requires good management skills in marketing, finance, customer service, and project management. Furthermore, it enables the entrepreneurs to critically analyze the market intelligence data and base their decisions on quantitative and qualitative analysis methods.

The problem regarding the lack of business and management skills is profound. According to Ibrahim and Soufani (2002), few women enroll into entrepreneurship in business 
schools; $18 \%$ of female start-up founders have MBAs, $31 \%$ of them have Master's in other fields other than Company Operating Activity and MBA, and 5\% with PhDs. The gender differences in the enrolment to entrepreneurial courses at Canadian universities are significant. The percentage of females registered at technological entrepreneurship undergraduate and graduate courses in 2002 was $21 \%$ and $20 \%$ respectively (Menzies and Tatroff, 2006).

Nevertheless, the interviewees suggested that there are ways to overcome the challenge of the lack of business and management skills by using entrepreneurial aid programs such as Lead-To-Win for Women and the TIM program: "Lead-to-Win program provides information on how to start up high tech companies. Marketing solutions for problems are very useful by doing presentation and discuss your ideas with others" (Interviewee 3). Other factors such as the experience gained over time helps to solve this challenge. The percentage of small businesses owned by entrepreneurs with more than 10 years of experience grew from $69 \%$ to $77 \%$ of all small and medium enterprises operating in Canada (Industry Canada, 2013). 50\% of female entrepreneurs owning small firms have less than 10 years of experience (TD Economics, 2012).

The interviewed female technology entrepreneurs explained that the lack of financial support is essential because they find it difficult to get funding: "This keeps the challenge cycle going for females because if they don't have the financial support, it is simply unreal to expect they can be successful unless they have enough funds of their own saved up to start up the business" (Interviewee 3). Women seem to rely on their family members or friends to borrow money and start their business; "I used my own personal funds, it was easy because my husband has well-paying salary" (Interviewee 2). According to Industry of Canada (2012), 59\% of females finance their businesses from their retained eirnings, $56 \%$ of them use their credit cards, $47 \%$ use their private sources (79\% of private sources are personl savings, $35 \%$ of private 
sources are friends and families, and $32 \%$ of the private sources are the family savings), and $39 \%$ of them use the bank loans to finance their businesses.

Two out five interviewees stated that they acquired funds from the government: "I called my IRAP (Industrial Research Assistance Program). After few days my IRAP-ITA called me (IRAP-Industrial Technical Advisor). I don't feel lonely ever since” (Interviewee 5). “The Canadian society supports females to start-up, and it does not differentiate between men and women" (Interviewee 2). However, female entrepreneurs tend to apply less for funds. According to TD economics (2012), the financing propensity between male and females is not significantly different $(85 \%$ of men and $83 \%$ of surveyed women stated that as company owners they did not look for financing because they did not need it). The lack of financing is possibly due to homophily in acquiring financing which limits the chances of females in acquiring funds (Bennet and Dann, 2000). Also, the venture capitals and angels are concentrated in Ontario and Quebec which limits the chances of entrepreneurs from other provinces (Ontario contains $47 \%$ of the total venture capital stock available in Canada and Quebec contains 21\% of it) (Cayen, 2001).

High-technology female entrepreneurs said the motivation is relevant to start-up and grow a business. Thus, the lack of motivation is a problem: "You will need a lot of motivation after a bad experience so you can keep going! Again, a strong support network will help you to stay motivated at the worst of times and in general if you became interested in the first place, I think you have the motivation to do well" (Interviewee 3). The lack of motivation is obviously influenced by the other factors such as the family obligations, lack of financial support, the lack of technological innovative business ideas, luck of sufficient business network, and the lack of management and business skills. Further research is required to test the correlation between these factors. Motivation could probably be enhanced through entrepreneurial education; $40 \%$ of 
students who attended entrepreneurship courses ended up starting their own businesses, 30\% joined their families' businesses while $30 \%$ joined the corporate world as employees worked for large organizations (Ibrahim and Soufani., 2002; Upton et al., 1995). According to Menzies and Paradi (2003), 40\% of Canadian engineering schools' graduates who attended entrepreneurship courses and training started their own small businesses.

Contrary to expectations, interviewed female entrepreneurs said that family obligations are rather insignificant challenge to start-ups; "I don't think family obligations are a major barrier in this day and age. We live in a time where both the husband and wife need to work in order to maintain their households and we have good supports such as daycare and babysitters to care for our children" (Interviewee 3). This is true especially if the family members are very supportive; "I have been very lucky because my husband and my son have been always supportive. My son and my husband witnessed every step. I spend time with my son especially for his music, he is a violist and he also plays piano, so we go together to concerts" (Interviewee 4).

Also, the family obligations are not exclusive to the high-technology entrepreneurs. They might be more important for female entrepreneurs in traditional sectors where the nature of their business fails to give them time and place flexibility. (According to TD economics (2012), 25\% of female entrepreneurs from all sectors chose to limit their growth to maintain the balance between work and family obligations, and female entrepreneurs opt to fix a growth threshold beyond which they do not want their enterprises to grow. Female technology entrepreneurs interviewed in this research were not asked about the threshold or the limitation of the growth, and this might be an explanation of the contradiction between the statistics and literature with the findings of this study. 
Interviewed women entrepreneurs said that "Risk to Promise" and "Overcoming previous Bad Business Experiences" were not crucial. "Risk to promise is somewhat of a challenge for female entrepreneurs because it depends on how they can convince the lenders that their business idea and business plan will be successful” (Interviewee 3). Moreover, ““'Overcoming bad business experiences" is of course important in general, but I don't think it's a major challenge for females specifically" (Interviewee 3). These two challenges are affected by the other challenges especially the lack of sufficient business network, the lack of financial support, the lack technological innovative business ideas, and the lack of management and business skills. The sufficient business network and the availability of financial resources leave no place to the risk to promise to be considered. Also, entrepreneurs may not like to commit and be in debt (4.44\% of male and $5.77 \%$ of women stated that they did not apply for external financing because they disliked being in debt) (Orser et al., 2006).

In sum, it can be argued that high-technology female entrepreneurs face four different categories of challenges (Opportunity Recognition, Impractical Education, Entrepreneurial Support Network, and Personal Commitments). Thus, Opportunity Recognition challenges include the Lack of Management and business skills and the Entrepreneurial Support Network challenges. In this vicious sector the education is very important because it takes creativity to solve problem by inventing technological innovative products. Moreover, female entrepreneurs in the high-technology must build up strategies to create a strong business network to be able to overcome the business start-up, and growth challenges.

The second category is the Impractical Education. It includes the Lack of Business and Management Skills, and the Lack of Motivation. Entrepreneurs need to acquire high management skills to adapt to the business model and to implement adequate strategies and 
maintain their businesses' growth. Also, the Lack of Motivation is correlated with education. Females with good education will be able to find opportunities and start their businesses

The third Category is the Entrepreneurial Support Network. It includes "Overcoming bad Business Experiences" and the "Lack of Financial Support". This category is important because of the lack of financial support challenges. Female entrepreneurs in the high technology need a strong entrepreneurial support to be able to overcome the business start-up, and growth challenges. Also, the results are very important for the authorities to draw effective and relevant strategies to help the female high technologies to overcome their challenges such as creating business and investment accompanying institutions.

Finally, the Personal Commitments category is less important for high technology female entrepreneurs. The personal commitments include the Family obligations and Risk to Promise. They said that they are not very important for them because they face harder challenges and because their families are supportive. This is a key finding of the paper because it contradicts the initial assumption that the family obligations is the most important challenge preventing females from starting business in the high technology sector. The time and place flexibility in the high technology sector make females more comfortable to work from their houses. This is the explanation of the least importance given to the family obligations by the high-technology female entrepreneurs during the interviews.

\subsubsection{Consistency with literature}

Contrarily to literature that puts the financial support as the first barrier for start-up high technology Business (Kamaruzzaman et al., 2008; Headd, 2003); the interviews show that Impractical Education and Opportunity Recognition challenges have the same importance for 
female entrepreneurs. The Opportunity Recognition challenges are very important in the field of high technology. Entrepreneurs with high education and technological innovative ideas are specialized individuals deploying their skills along with heterogeneous assets to create a value added for the company as defined by Bailetti (2012).

"An investment in a project that assembles and deploys specialized individuals and heterogeneous assets that are intricately related to advances in scientific and technological knowledge for the purpose of creating and capturing value for a firm" (Bailetti, 2012: p 9). The interviewed high-technology female entrepreneurs considered the lack of the sufficient business network to be among the most important challenges facing them. All interviewed entrepreneurs agreed on the importance of the business network. The sufficient Business Network plays a major role to support the company especially at the beginning of the company's operations: "It's not what you know but who you know" couldn't be more accurate, in my opinion" (Interviewee 5). It is one of the most business growth and sustainability determinants because it helps them to acquire funds, information, connections, experience and opportunities to build a viable market share (Hanson and Blake, 2009).

The Impractical Education challenges have the greatest impact on high technology female entrepreneurs. Adequate education that combines good business and management skills is necessary for any successful entrepreneur in the high-technology sector. This encourages more females with technological background to enroll in management and business schools, and females with business education to enroll in technology programs or in programs combining both concentrations. Education programs offering both backgrounds provide entrepreneurs with the required knowledge to start up high technology ventures. As a result, the number of female entrepreneurs in the technology field increases. 
The educational skills are key requirements of the entrepreneurial mindset. Entrepreneurs are growth oriented; they work to promote their flexibility, productivity and innovation by using their previous education in both technology and business. This complies with the definition of "a growth-oriented perspective through which individuals promote flexibility, creativity, continuous innovation and renewal" (Ireland et al., 2003, p 968).

The majority of literature on female entrepreneurship mentioned that female entrepreneurs start up traditional business rather than offering high technology products and services. This is justified by the lack of the necessary knowledge. According to Scarborough and Zimmerer (2000, p.4), entrepreneurship has been defined as "being able to create a new business based on understanding the necessary resources and opportunities and taking risk in uncertain business environment to get good growth and revenue". This means that we must encourage female entrepreneurs with the necessary knowledge and skills to create technological innovative firms. Therefore, female entrepreneurs who want to start up their business in high technology sector should have the appropriate knowledge on technology innovation and management skills (Baldwin and Hanel, 2003). The practical education helps people to be motivated to start their businesses and to overcome the obstacles (Pena, 2002)

Entrepreneurial Support Network challenges include the lack of lack of financial Support, and "Overcoming bad Business Experiences". The finding of the research complies with the suggestions of the literature review in terms of the importance of the Entrepreneurial Support Network challenges. The answers of female entrepreneurs show the importance of funding challenge because they struggle to secure funds or they use their personal funds or borrow money from their relatives and friends (Government of Canada, 2012). Authors such as Bennet and Dann (2000) complied with this statement and said that females prefer to use internal 
financial support such as borrowing money from family and friends. Also, one possible explanation is that females don't apply because they think that funders don't trust female entrepreneurs as much as male entrepreneurs because they don't look at the enterprises as a legal entity but they look at it as an individual (Mezias, 2000). According to Coleman (2000) females pay higher interest rates than men (Coleman, 2000).

Also, the entrepreneurial support network helps females overcoming their bad business experiences. There are different forms of help that can make females overcome their bad experiences. For instance, mentorship supports female entrepreneurs to build their ideas and be confident to start new businesses (White House Council, 2012). Many females faced difficult circumstances and bad business experiences because they did not have practical management and business skills, technological ideas and time devotion to business. According to Wadhwa et al. (2009); 96\% of respondents mentioned previous work experience as an important factor in being successful in high technology businesses.

The Entrepreneurial Support Network challenges determine the size of the company, its objectives and results. Katz and Green (2007) mentioned that the small companies are characterized by the limited development, short-term strategy, lower growth, and they rarely offer high technological innovative products and services. The literature review is on the same line with the findings of the research since both of them show the importance of the Entrepreneurial Support Network.

The Personal commitments were not of major importance for the interviewed hightechnology female entrepreneurs. The Family obligations are less important for high technology female entrepreneurs while starting up their businesses. This contradicts the initial assumption of 
the research and different other papers findings that say family obligations challenge is the most important challenge for high technology female entrepreneurs. However, the difference can be explained since high technology female entrepreneurs enjoy time and place flexibility that is not available for entrepreneurs in other industries and the new facilities in life such as technology, community centers and daycares. Further research is required to investigate the difference in the importance of the family obligations and personal challenges between the high technology female entrepreneurs and the traditional industries female entrepreneurs.

The lack of financial support encourages them to borrow money from private organizations such as banks. Opening up high technology businesses require large funds which means that the personal funds may not be enough. In this case high technology female entrepreneurs need to acquire funds from capital investment companies, government and banks. The Risk to promise makes female entrepreneurs reluctant to approach the funders. This impacts high technology female entrepreneurs and puts pressure on them which could make them financially weak and makes them give external personal commitment to payback their loans. The tendency of high technology female entrepreneurs to be self-funded entrepreneurs might be because they don't apply or apply less to the external funding such as investors funding, external grants and/or bank loans as proved by empirical evidence by Industry Canada Report in 2012 (Government of Canada, 2012).

This study encourages further research to be addressed to discuss the differences in priorities between the female entrepreneurs in the high technology sector and the female entrepreneurs in other sectors. Furthermore, future research needs to investigate the difference in family obligations importance among female entrepreneurs inside the high technology industry. In other words, will female entrepreneurs consider the family obligations more important when 
their businesses grow? If, so, what is the turning point (revenues and company dimension) at which the family obligations and personal challenges will increase in priority for female entrepreneurs in high technology?

This research found that there are significant problems and challenges faced by hightechnology female entrepreneurs due to the vicious characteristics of their businesses' dimensions (small business) and the sector of operations (high technology sector). A specific contribution was that the study was able to shed light on the relative importance between these challenges. The research urges the policy makers, investment practitioners and education institutions to put in place educational programs, assistance and female project funding institutions and policies to help female entrepreneurs in general and high-technology female entrepreneurs specifically to start their businesses and overcome the difficulties and challenges they face.

It is very important for female entrepreneurs to build relationships with policy makers, investment practitioners and other institutions in order to develop their network and enable their companies to grow. The entrepreneurial line of work is very competitive because everyone wants to create and grow a business even without necessary skills to deal with start-up challenges and difficulties especially in the high technology sector. Moreover, the lack of trust may affect new start-up technology entrepreneurs to get funds; however, well-educated high technology female entrepreneurs can find solutions to overcome this situation by creating an interesting idea. This is the reason why adequate educational programs should be created to help all the entrepreneurs to successfully start and grow their businesses. 


\subsection{Strategies:}

The strategies should not be only microeconomic but they should also be macroeconomic. Policy makers and educational institutions should be principal pillars in the future efforts to help female entrepreneurs acquire the necessary knowledge to start their businesses. However, female entrepreneurs accompanying institutions should be created to help female entrepreneurs to grow and sustain their business.

\subsubsection{Female Entrepreneurs Strategies}

\section{a) Partnership with Entrepreneurial Support Organizations}

Business alliances with organizations like Lead-To-Win for Women are useful because they help female entrepreneurs to get enough support to overcome their challenges. For Instance, Lead-To-Win for Women has been created to help female entrepreneurs start and build up their businesses. It helps them to overcome any difficulties and challenges to start their businesses. Also, it helps them to build up connections with the right people to get funds and find opportunities. This type of organizations is promising if policy makers help them grow. An inspiring model for these organizations is the Women Empowerment program that is managed by the United Nations. The program helps females in different regions of the world to funds, get information about the investment opportunities and get electronically in touch base with the development practitioners and decision makers in different countries (United Nations, 2013).

This model should be adopted to help females from Canada in all domains to start up their businesses. These organizations are a great opportunity for high technology female entrepreneurs to build up connections and get the necessary funds and link connections with policy makers and investors to get information about business opportunities and problems that need to be solved (Lead To Win for Women, 2013). 
Essentially, building connections with organizations and institutions like Lead-To-Win for Women must be at the heart of high technology female entrepreneurs' public relations campaign, marketing, and funding strategies. The investment sector has been increasingly competitive and so does the need of strong market and business alliances. No company in the market can survive by itself. For this reason the paper strongly recommends that high technology female entrepreneurs build up relations with organizations like Lead-To-Win for Qomen.

\section{b) Partnerships with Educational Programs and Research Institution}

The partnership with programs like Carleton University's TIM program helps female entrepreneurs to build up necessary management knowledge in the field of technology without studying technology and management. The TIM program, for instance, helps its students to create technological innovative ideas and present them as solutions to existing businesses. Thus, in this case female entrepreneurs do not need to study technology and management to get solutions to their business problems. Also, the partnership with research institutions like TIM review helps female in the high technology sector to get ideas and develop them through students and researchers who may take their cases to do research and make publications.

The right education helps investors and entrepreneurs to reduce the cost of the product development and the management cost. However, since it's hard for entrepreneurs to get an education combining both fields' knowledge; the partnerships with education programs and research institutions are the right solution for this problem.

\section{c) Partners and Co-founders}

Partners and co-founders is a strategy that most of high technology companies use to solve their problems. The co-founders are two kinds (investors, and programmers). Some high technology talents find partners who are able to finance the project and/or partners who have 
technological skills. As we can conclude from the interviews; Interviewee 1 said "So having a partner who has knowledge in whatever it is; you can make software for that because there are many things that could be improved by a software, there are so many industries that we don't really get into because maybe our culture of software development does not fit into that industry, so yeah definitely its really good to have a team and that what I am doing". Also, other interviewed female entrepreneurs said that they have co-founders because of their technological skills.

Finding co-founders is a good strategy because it saves time and financial resources for the company. Spending on the development, prototype and production is very difficult at the beginning of the company and having co-founders who participate in the development and the financing of the company is very helpful "I have a business partner and now I have people that I work closely with that I really have. I think it is really important to have a business partner but not necessary depending on the idea what it is? But usually you should have team of people who are going to invest and have different expertise" (Interviewee 1).

\subsection{Stakeholders' Strategies}

\subsubsection{Events}

The creation and organization of gathering events for high technology female entrepreneurs is helpful because it will attract entrepreneurs who are already in the field with those intending to open up new businesses. Funding institutions and other entrepreneurial support organizations should be part of these events to encourage females to attend these events and answer all the inquiries of participants. 


\subsubsection{Annual High Technology Female Business Award}

The creation of awards such as "Exploriem Bootstrap Awards on Lead to Win Category" will have a great impact on the high technology sector and the high technology female entrepreneurs' community. Interviewee 4 has won this award. These awards have multiple effects. First, they will encourage female entrepreneurs to create more innovative ideas and grow their businesses. This will increase the value added creation in the high technology sector. Second, this award increases the competition between the high technology female entrepreneurs and encourages them to improve their businesses and create new innovative ideas. Third, it encourages new females entrepreneurs to entre to the high technology sector because of the dynamism and competition created because of the award.

\subsubsection{Creation of Educational Programs and Research Institutions}

The decision makers, education practitioners and specialists must cooperate together to create new educational programs allowing students to acquire both technology and management knowledge and prepare them for an entrepreneurial career. Also, short term programs combing the two fields are also a high necessity for the existing entrepreneurs who need to acquire more knowledge to improve the situation of their businesses. Moreover, the creation of research institutions to work with female entrepreneurs to overcome their management and technological ideas is a priority to stimulate innovation and put them at the heart of high technology innovation support.

\subsubsection{Funding Institutions}

The federal government and the provincial governments in Canada should create institutions to fund high technology female entrepreneurs' projects. Standards should be in place to avoid the bureaucracy practices and prevent them to appear in these institutions. Also, one of 
the big problems in this case is the collaterals. The funding must take into consideration only the idea and the curriculum of the entrepreneur and their credit history. By doing so, the number of female high technology female entrepreneurs will increase and this will increase the national GDP and help creating jobs. The identified problems and challenges, as well as suggested coping strategies are illustrated in Appendix D.

\subsection{Lessons learned}

The study contributes to current literature on female technology entrepreneurship and practice in multiple ways. These contributions could be described through a set of lessons learned. In sum, the key contributions relate to the fact that the study was able to identify and categorize the problems and challenges perceived by female technology entrepreneurs in a way that has not been presented in previous literature. In addition, the study suggested that there are differences in the relative importance between the challenges. This categorization and relative ranking provided by the study make it easier for researchers and practitioners to focus on the relevant challenges that may become obstacles to female technology entrepreneurship. Ultimately, the study puts forward that external challenges to female technology entrepreneurship may be more relevant than internal factors. External challenges are directly related to operating a business, whereas internal factors are more motivational and psychological factors preventing an aspiring entrepreneur to start-up a business. The key lessons learned are further elaborated in the following.

The first lesson to learn is that the technological and the management knowledge are very important challenges facing female entrepreneurs in the field of high technology. The technological knowledge helps entrepreneurs to develop their ideas by themselves; thus, they can reduce the development expenses and the risk to lose their ideas. Also, the technological 
knowledge helps female entrepreneurs to be time and money efficient because they can respond to their customers' inquiries and think about the best solutions. However, developers hired as partners can be a good solution to overcome the high development cost. On the other side, the business and management skills are also very important for female entrepreneurs to better manage their businesses and adopt the best business model. As a result, contrarily to entrepreneurs from traditional sectors, where the personal and entrepreneurial support challenges are more important, the educational challenges are important challenges facing female entrepreneurs in the high-technology sector contrarily.

The second lesson to learn is that the family obligations are less important for female entrepreneurs in the high-technology field compared to the female entrepreneurs in the other fields because of the time and place flexibility as female entrepreneurs in high technology field can work from home and because of technology advancement, family support, childcare and other facilities. However, further research is needed to find out if there is a turning point at which high technology female entrepreneurs will start considering family obligations more important when their companies grow and they must have an office outside their houses.

Partnerships with programs like TIM program are beneficial for the female entrepreneurs and help them to get advices, assistance, new ideas in the field of technological innovative ideas and business and management advices to help their businesses grow. Also, partnerships with organization like Lead-To-Win for Women help female entrepreneurs to build up connections to create a viable market share.

The creation of short period management and technology programs like TIM program is very beneficial for the high technology entrepreneurship for both male and females. Also, the 
creation of organizations to accompany entrepreneurs and help them overcome their difficulties is as important as other possible reforms in education and policies. The federal and provincial governments should work intensely towards the implementation of these programs and entrepreneurial support organizations and institutions. 


\section{Chapter 6: Conclusion and Future Research}

\subsection{Conclusive discussion}

There is probably no big difference in terms of innate abilities between female and male high-technology entrepreneurs. The differences are created through social, educational and entrepreneurial support network contexts. There is an apparent difference between hightechnology female entrepreneurs and female entrepreneurs from other industries. High technology female entrepreneurs consider family obligations and personal commitments less challenging than female entrepreneurs from other sectors because of the flexibility of their work. On the other side, practical education and opportunity recognition are very important for high technology female entrepreneurs because they help entrepreneurs to develop innovative ideas and use contemporary management methods to manage their businesses.

Opportunity Recognition challenges (lack of technologically innovative business ideas) are important because allows entrepreneurs to create products and find ideas either from the market requirements or from direct request from institutions. Impractical Education (lack of business and management skills, and lack of motivation) and Entrepreneurial Support Network challenges (lack of financial support, and overcoming bad business experiences) are also important for women in high-technology sector while personal commitments come at the last importance. This is due to the vicious character of the high technology sector itself. Further research is required to investigate these differences with regard to the dimension of business.

A solution for high-technology female entrepreneurs is to acquire adequate education before starting up their businesses or get partners and co-founders to help in development. New programs combining both technological and business and management knowledge to be able develop their businesses with less cost and high talent. Many ideas can be implemented to fill 
these educational gaps such as creating co-op programs within business schools to enable females who are interested to high-technology entrepreneurial career to work in high technology companies and gain valuable experience. This experience opens opportunities to acquire knowledge and become entrepreneurs in the high technology industry. On the other side, the creation of entrepreneurship support institutions is very important to help high-technology female entrepreneurs.

To help high-technology female entrepreneurs start up successful business and increase their number in the sector, decision makers and different stakeholders must make more efforts. These efforts can be in form of events organized to introduce entrepreneurs and stakeholders to each other, create awards to increase competition between female entrepreneurs, and create entrepreneurial support and funding institutions.

\subsection{Limitations of the research}

There are several methodological limitations that must be noted. The small sample size and insufficient availability of data are methodological limitations of the research. The small sample size of five women technology entrepreneurs may affect the results significantly because small samples include high risk of biasness and selectivity. Large samples, however, make the researchers selectivity less possible and it also makes the sample statistics gradually converging to the population parameters (real values). In addition, large samples are difficult to manage when the primary research method is qualitative research. The fact that there was no wide range of data available also limits the results. This study used a sample of high-technology female entrepreneurs from Ottawa; so, it is important to note that the data possibly may not apply to experiences of high-technology female entrepreneurs from other Canadian cities. 
The process used to collect data is another methodological limitation. Open questions give higher possibility for self-report biased data because the researcher asks question and let entrepreneurs express their ideas, the researcher did not intervene unless there was a need for more clarification or further questions. Self-reported data has bias that can affect the study's results because participants may have selective memory about their experiences. The selective memory has tendency to attribute negative characteristics or outcomes to external factors and positive outcomes to internal personal factors. It is very likely that participants may remember or not remember specific events from the past that have the potential to impact the results. The only solution to the self-report bias is the use of larger samples.

Yet another limitation of this study is that there is a lack of prior researches on the challenges facing high-technology female entrepreneurs, especially in Canada. As cited in the literature review, there are plenty of studies available on the meaning of entrepreneurship and the challenges associated with starting one's own business. However, the literature is very limited in topics related to high-technology female entrepreneurs. Subsequently, the lack of previous research put forward the problem of dated publications that form the basis of the literature review. Many of the cited scholarly works date from 1980s, 1990s, and early 2000s, whereas the researcher acknowledges that the world around has changed, and women's role in societies has come increasingly explicit and equal to that of men over time.

The attribution bias is a serious limitation because it may alter the results of the study since the respondents had to answer open questions. Anecdotally, participants may not have wanted to admit these concerns or may subconsciously have decided that their problems cannot be attributed to personal factors. A larger sample size and a questionnaire with reverse scaling may help to eliminate this potential self-reporting bias. 


\subsection{Contributions and Future Directions}

This research addresses the challenges faced by high technology female entrepreneurs. Although the literature review has discussed the challenges faced by female entrepreneurs; previous researches did not discuss all the challenges faced by high technology female entrepreneurs together in one paper but they treated them separately. However, the cross literature investigation and interviews enabled the research to bring up all the challenges and put them into one paper. The cross literature review investigation allowed the collection of multiple strategies to overcome the high technology female entrepreneurs' challenges to either start up or grow their high technology business. The previous researches did not address the differences between high technology female entrepreneurs and female entrepreneurs from other industries but this research has revealed differences in the challenges' priority between the two kinds of entrepreneurs using a qualitative analysis.

This research brings new insights from real life problems faced by high technology female entrepreneurs. This research provides clear view of the challenges so that policy makers, high technology female entrepreneurs and other stakeholders are aware of these challenges and work to solve the complexity and put in place measures and procedures to address these challenges. This research encourages the creation of more programs to support start-up technology entrepreneurs. It essentially focuses on the challenges faced by high technology female entrepreneurs and their importance for the interviewed high technology female entrepreneurs. The implementation of new systems, programs and institutions to support female entrepreneurs will encourage females to start high technology businesses.

The most difficult barriers affecting high technology female entrepreneurs are the opportunity recognition, impractical education and entrepreneurial support barriers because it's 
hard to acquire them. These barriers have been discussed throughout the interviews to confirm their importance from female entrepreneurs themselves. These challenges are hard to overcome if there is less support from the decision makers and the environment of the female entrepreneurs. The interviews and literature review mention some strategies to aid high technology female entrepreneurs in their journey. These strategies are based on partnerships and alliances with universities and female entrepreneurs support institutions such as Lead-To-Win for Women to help companies with entrepreneurial support and to acquire adequate education. Interviewed high technology female entrepreneurs are willing to share their experiences in high technology sector. This creates easier ways to focus on the main problems and create the most suitable solutions for them.

Interviewed high technology female entrepreneurs appreciate the help of the TIM program because they get funds and technological support to start-up their high technology businesses. High technology female entrepreneurs think that the TIM program assistance helped them to create successful high technology businesses. Through the help of the TIM program they acquired funds, management, and business advises from experts in the technology entrepreneurial field. It is more likely to create a successful high technology company using TIM program experts and high technology management practitioners' advices and help.

These challenges discourage many females to start up new businesses in the high technology sector and lead them to create traditional businesses instead of facing hard challenges. This research gives a clear overview of these challenges to enable decision makers adjust policies and create organizations to keep the investment opportunities open because the missed chances of female investments cause the economy losses in jobs, technology solutions 
and value added. Creating solutions for these challenges will help females to overcome these challenges by having the right people to help them deal with their problems.

Support programs for new start-up technology entrepreneurs is every important to address the challenges faced by female entrepreneurs. These programs are educational programs, entrepreneurial support programs that are managed by public, semi-governmental, and funding institutions. However, these programs are not sufficient to provide support for high technology female entrepreneurs because these programs are not permanently adjusted based on researches. Continuous researches must be done to address rising challenges for high technology female entrepreneurs because they currently face new challenges that were not discussed in the past and will face in the future challenges that don't exist presently. It takes lot of work to make solutions for these permanently changing challenges. TIM review is one of the most suitable programs providing excellent feedback for new start-up technology entrepreneurs because it includes all solutions for new challenges such as permanent research, funding possibilities for female entrepreneurs. It also helps the female entrepreneurs with experiences and knowledge from the TIM presentations. 


\section{References}

Adam, A., Emms, J., Green, E., \& Owen, J. (Eds.). (1994). Women, Work and Computerization: Breaking Old Boundaries - Building New Forms, North-Holland: Amsterdam.

Hampton, A., McGowan, P. \& Cooper, S. (2011). Developing quality in female high-technology entrepreneurs' network. International Journal of Entrepreneurial Behaviour \& Research, 17(6), pp. 588-606.

Alsos, G. A., \& Ljunggren, E. C. (1998). Does the business start-up process differ by gender? Alongitudinal study of nascent entrepreneurs. In Frontiers of Entrepreneurship Research, \& P. D. Reynolds et al., (Eds.), MA: Babson College, Wellesley.

Anna, AL, Chandler, GN, Jansen, E \& Mero, NP (2000) 'Women business owners in traditional and non-traditional industries', Journal of Business Venturing, 15, 3, 279-303.

Anon., (2010). Women entrepreneurs, Ottawa: Industry Canada.

Attila Bruni, A. Gherardi, S \& Poggio, B. (2004) .Entrepreneur-mentality, gender and the study of women entrepreneurs. Journal of Organizational Change Management. Vol. 17 No. 3, 256268.

Babcock, L., S. Laschever, M. Gelfand, and D. Small. 2003. Nice girls don't ask. Harvard Business Review 81, no. 10: 14-16.

Bailetti, T., Bot, S. D., Duxbury, T., Hudson, D., McPhee, C., Muegge, S., Tanev, S., Weiss, M., Wells, J. \& Westerlund, M. (2012). An Overview of Four Issues on Technology Entrepreneurship in the TIM Review. Technology Innovation Management Review, April, 2834).

Baker, M. J., \& McTavish, R. (1976). Product policy and management. New York: Macmillan.

Becker-Blease, J. R., \& Sohl, J. E. (2007). Do women-owned businesses have equal access to angel capital?. Journal of Business Venturing, 22(4), 503-521.

Belcourt, M. (1990). A family portrait of Canada's most successful female entrepreneurs. Journal of Business Ethics, 9(4-5), 435-438.

Berry, M., (1998). Strategic Planning in Small High tech Companies. Long Range Planning, 31(3), pp. 455-466..

Butter, E. H., (1993). Female Entrepreneurs: How Far Have They Come? Business Horizons Journal, 36: 59-65. 
Bruni, A., Gheradi, A. \& Poggio, B., (2004). Entrepreneur-mentality, gender, and the study of women entrepreneurs. Journal of Organizational Change Management, 17(3): 256 - 268

Butler, J. (2003). New Perspectives on Women Entrepreneurs, Information Age Publishing Inc., Greenwich, Connecticut.

Brush, C. G., Carter, N. M., Gatewood, E. J., Greene, P. G., \& Hart, M. M. (2006). The use of bootstrapping by women entrepreneurs in positioning for growth. Venture Capital, 8(1), 15-31.

Canada, I., (2010). Women entrepreneurs, Ottawa: Small business financing profiles .

Carter, NM, Gartner, WB, Shaver, KG and Gatewood, EJ (2003) 'The career reasons of nascent entrepreneurs', Journal of Business Venturing, 18, 13-39.

Cassar, G., (2006). Entrepreneur Opportunity Costs and intended venture growth. Journal of Business Venturing, 21(5): 610-632.

Cayen, J. P. (2001). Venture capital in Canada. Bank of Canada.

Cliff, J. E., (1998). Does One Size Fit All? Exploring The Relationship Between Attitudes Towards Growth, Gender, and Business Size. Journal of Business Venture, 13(6): 523-542.

Cooper , S. \& Park , J., (2008). The impact of "incubator" organisation on opportunity recognition and technology innovation in new entrepreneurial high-technology ventures. International Small Business Journal, 26(1): 27-56.

Coleman, S., (2000). Access to Capital: a Comparison of Men and Women-Owned Small

Cromie, S., (1987). Motivations of aspiring male and female entrepreneurs. Journal of Organizational Behavior, 8(3): 251-261.

Devine, T. J. (1994). Characteristics of self-employed women in the United States. Monthly Labor Review, 20-34.

Dollinger , M., (1999). Entrepreneurship: Strategies and resources. Upper Saddle River, N.J.: Prentice Hall.

ECDGEI. (2008). Evaluation on policy: Promotion of women innovators and entrepreneurship, DG Enterprise and Industry, European Commission. Available at http://www.ec.europa.eu/enterprise/dgs/eval.htm, accessed 27 January 2010.

Eisenhardt, K., (1989). Building theories from case research. The Academy of Management Review , 14(4): 532-550.

Fergus, E. O., Avellar, J. W., Fairweather, G. W., \& Fleischer, M. (1980). Innovation and social process: A national experiment in implementing social technology. New York: Pergamon Press 
Segal, G., Borgia, D., \& Schoenfeld, J. 2005. The motivation to become an entrepreneur. International Journal of Entrepreneurial Behaviour and research, 11(1): 42-57.

Government of Canada, 2012. Industry Canada. [En ligne] Available at: www.ic.gc.ca/eic/site/061.nsf/eng/02727.html.

Greene, P. G., Brush, C. G., Hart, M. M., \& Saparito, P. (2001). Patterns of venture capital funding: is gender a factor? Venture Capital: An International Journal of Entrepreneurial Finance, 3(1), 63-83.

Gupta, V., Turban, D.B., Wasti, A. \& Sikdar, A., (2009). The role of gender sterotypes in perceptions of entrepreneurs and intentions to become an entrepreneur. Entrepreneurship Theory and Practice, 33(2): 397-417.

Gundry, L. K., \& Welsch, H. P. (2001). The ambitious entrepreneur: high growth strategies of women-owned enterprises. Journal of Business Venturing, 16(5), 453-470.

Harrison, R. T., \& Mason, C. M. (2007). Does gender matter? Women business angels and the supply of entrepreneurial finance. Entrepreneurship Theory and Practice, 31(3), 445-472.

Ibrahim, A. B., \& Soufani, K. (2002). Entrepreneurship education and training in Canada: a critical assessment. Education+ Training, 44(8/9), 421-430.

Industry Canada. (2010). Small business financing profiles. Women entrepreneurs. Ottawa: Small Business and Tourism Branch.

Industry Canada, (2012). Archived-Financing SMEs in Canada: Barriers Faced by Women, Youth, Aboriginal and Minority Entrepreneurs in Accessing Capital - Phase 1: Literature Review , Ottawa: Industry Canada.

Industry Canada, (2012). Financing SMEs in Canada: Barriers Faced by Women, Youth, Aboriginal and Minority Entrepreneurs in Accessing Capital - Phase 2: Gap Analysis and Recommendations for Further Research, Ottawa: Industry Canada.

Industry Canada. (2013). Key Small Business Statistics. Ottawa: Industry Canada.

Ireland, R., Hitt, M. \& Sirmon, D., (2003). A model of strategic entrepreneurship: The construct and its dimensions. Journal of Management, 29(6), 963-989.

Jalbert, S. E. (2000). Women Entrepreneurs in the Global Economy. Retrieved

Jennings, J. E., \& Cash, M. P. (2006). Women's entrepreneurship in Canada: progress, puzzles and priorities. Growth-oriented Women Entrepreneurs and Their Businesses-A Global Research Perspective.

Johne, M., (2012). Small business managing. [En ligne] 
Available at: www.theglobeandmail.com/report-on-business/sb-managing/why-arent-there-morewomen-in-tech-start-ups/article533618/.

Katz, J., \& Gartner, W. B. (1988). Properties of emerging organizations. Academy of Management Review, 13(3), 429-441

Kirkwood, J. \& Walton, S., (2010). What Motivates ecopreneurs to start business? International Journal of Entrepreneurial Behaviour \& Research, 16(3), pp. 204-228.

Longstreth, M., Stafford, K., \& Mauldin, T. (1987). Self-employed women and their families: Time use and socioeconomic characteristics. Journal of Small Business Management, 25(3), 3037.

Liu, Y. (2000). An overview of angel investors in Canada. MFA paper.

LTWW, (2013). Mission and Vision. [En ligne] Available at: www.ltw-women.ca/mission-andvision.

Mathew, V., (2010). Women Entrepreneurship in the Middle East: Understanding Barriers and Use of ICT for Entrepreneurship Development. International Entrepreneurship and Management Journal, 6: 163-181.

Mayer, H (2006) 'Economic trends and location patterns of women high technology entrepreneurs', 298-309 in A Zacharakis et al. (eds)(2006). Frontiers of entrepreneurship research, Wellesley, Babson College.

Mezias, S. J. \& Kuperman, J. C. (2000). The community dynamics of entrepreneurship: the birth of the American film industry, 1895-1929. Journal of Business Venturing, 16 (3): 209-233.

Menzies, T. V., \& Paradi, J. C. (2003). Entrepreneurship education and engineering studentsCareer path and business performance. The International Journal of Entrepreneurship and Innovation, 4(2), 121-132.

Menzies, T. V., Diochon, M., Gasse, Y., \& Elgie, S. (2006). A longitudinal study of the characteristics, business creation process and outcome differences of Canadian female vs. male nascent entrepreneurs. The International Entrepreneurship and Management Journal, 2(4), 441453.

Menzies, T. V., \& Tatroff, H. (2006). The Propensity of Male vs. Female Students To Take Courses and Degree Concentrations in Entrepreneurship1. Journal of Small Business \& Entrepreneurship, 19(2), 203-223.

Morck, R. K., Stangeland, D. A., \& Yeung, B. (1998). Inherited wealth, corporate control and economic growth: The Canadian disease (No. w6814). National Bureau of Economic Research. 
Mwobobia, F.M. (2012). The Challenges Facing Small-Scale Women Entrepreneurs: A Case of Kenya. International Journal of Business Administration, 3(2): 112-121.

Carter, N.M., Gartner, W.B., Shaver, K.G. \& Gatewood, E.J. (2003). The career reasons of nascent entrepreneurs. Journal of Business Venturing, 18(1): 13-39.

Neyens, I., Faems, D., \& Sels, L., (2010). The impact of continuous and discontinuous alliance strategies on startup innovation performance. International Journal of Technology Management, 52(3): 392-410.

Orser, B. J., Riding, A. L., \& Manley, K. (2006). Women entrepreneurs and financial capital. Entrepreneurship Theory and Practice, 30(5), 643-665.

Orser, B., Riding, A. \& Stanley, J. (2012). Perceived career challenges and response strategies of women in the advanced technology sector. Entrepreneurship \& Regional Development, 24(1/2): 73-93.

Orser, B., Sandra , A., Mary , A., Clare, B., Penny , C., Anne , D., et al. (2012). http://sites.telfer.uottawa.ca/womensenterprise/sites/sites.telfer.uottawa.ca.womensenterprise/file s/file/taskforce-report-2011.pdf. Ottawa: Ottawa University.

Packard, D., \& Packard, D. (1995). The HP way (p. 57). Recorded Books.

Pinchot III, G. (1985). Intrapreneuring: Why you don't have to leave the corporation to become an entrepreneur. University of Illinois at Urbana-Champaign's Academy for Entrepreneurial Leadership Historical Research Reference in Entrepreneurship.

Fonseca, R., Lopez-Garcia, P., \& Pissarides, C.A., 2001. Entrepreneurship, Start-up costs and employment. European Economic Review, 45(4-6): 692-705.

Morck, R.K., Stangeland, D.A. \& Yeung, B., (1998). Inherited Wealth, Corporate Control and Economic Growth: The Canadian Disease. National Bureau of Economic Research Working Paper Series, pp. 319-372.

Riding, A. L. (1998). Financing entrepreneurial firms: Legal and regulatory issues.

Riding, A. L., \& Short, D. M. (1988). On the estimation of the investment potential of informal investors: A capture/recapture approach. Journal of Small Business \& Entrepreneurship, 5(5), 26-40.

McGrath, R.G. \& McMillan, I.C., (1992). Elitists, Risk-Takers, and rugged individualists? An Exploratory Analysis of Cultural Differences Between Entrepreneurs and Non-Entrepreneurs. Journal of Business Venturing, 7(2): 115-135. 
Robinson, D.A. (2008). Entrepreneurial Challenges in South Africa. Journal of African Business, 5(2): 173-185.

Rothwell, R., \& Robertson, A. B. (1973). The role of communications in technological innovation. Research Policy, 2(3), 204-225.

Scarborough, N. \&. Zimmerer. T., (2000). Effective small business management: An enterpreneurial approach. Upper Saddle River, New Jersey : Prentice Hall, Inc.

Scott, S., (2000). Prior knowledge and the discovery of entrepreneurship opportunities. Organizational Science, 11(4): 448-469.

Shane, S., Locke, E.A. \& Collins, C..J. (2003). Entrepreneurial motivation. Human Resources Management Review, pp. 257-279.

Siddiqui, A.B. (2008). Problems Encountered by Women Entrepreneurs in India. International Journal of Applied Research \& Studies, Vol. 1(2): 1-11.

Sigismund, C.G. (2000). Champions of Silicone Valley: Visionary Thinking from Today's Technology Pioneers. New York: John Wiley \& Sons.

Simard, C., Henderson, A.D., Gilmartin, S., Schiebinger, L. \& Whitney, T. (2008). Climbing the technological ladder: Obstacles and solutions for mid-level women in technology. Boulder, CO: National Center for Women and Information Technology, University of Colorado.

Shane, S. \& Venkataraman, S., (2000). The promise of entreprenurship as field of research. The Academy of Management Review , pp. 217-226.

Shane, S., Locke, E., \& Collins, C. J. (2003). Entrepreneurial motivation. Human Resource Management Review, 13(2), 257-280.

Statistics Canada (2004). Labour force survey.

TD economics, (2012). The Venus vs. Mars Approach to Entrepreneurial Success in Canada. Toronto: TD Bank Group.

TD Economics, (2012). Canada's Small and Medium Sized Business Owners: Diverse Society in Microcosm. Toronto: TD Bank Group.

Thrasher, B. L. \& Smid, M. (1998). Smart women: Canadian business owners. Toronto: Macmillan.

Kane, T. (2010) — The Importance of Startups in Job Creation and Job Destruction,„ Kauffman Foundation Research Series, July 2010, along with previous work by others as cited by Kane. 
Thompson, J., (1999). The Word of the Entrepreneur- a new perespective. Journal of Workplace Learning: Employee Counselling Today, pp. 209-224.

Trichur, R., (2011). Small Business Funding. [En ligne] Available at: http://www.theglobeandmail.com/report-on-business/small-business/sb-money/business-

funding/canada-urged-to-support-its-female-entrepreneurs/article4182909/.

United Nations, (2013). Women Empowerment Program. [En ligne] Available at: ww.undo.org/content/undp/en/home/outwork/womenempowerment/overview.html

Upton, N., Sexton, D., \& Moore, C. (1995). Have we made a difference? An examination of career activity of entrepreneurship majors since 1981. Frontiers of Entrepreneurship Research, 727-728.

Utterback, J. M. (1971). The process of technological innovation within the firm. Academy of Management Journal, 14(1), 75-88.

Wickham, P. (2004). Strategic Entrepreneurship. Financial Times Prentice Hall, pp 400-619.

Mezias, S.J. \& Kuperman, J. (2000). The community dynamics of entrepreneurship: The birth of American film industry, 1895-1929. Journal of Business Venturing, 16: 209-233.

Wunker, S., (2005). Get the job done. Harvard Business Review, pp. 1-6. 


\section{Appendix A: Statistics on Female Entrepreneurship in Canada}

\section{Business Ownership by Gender distribution and Business Sector in Canada}

Figure 10 shows that only $16.8 \%$ of construction companies are wholly owned by women, and $66.7 \%$ of all Canadian construction companies are wholly owned male. $23.9 \%$ of agriculture companies are wholly owned by females, and $47.4 \%$ of all Canadian agriculture companies are wholly owned by males. Other sectors such as transportation, warehousing, manufacturing, wholesale, retail, accommodation and food services sectors experience the same patterns (Industry Canada, 2013).

Figure 10: Business Ownership Distribution by Gender and Business Sector

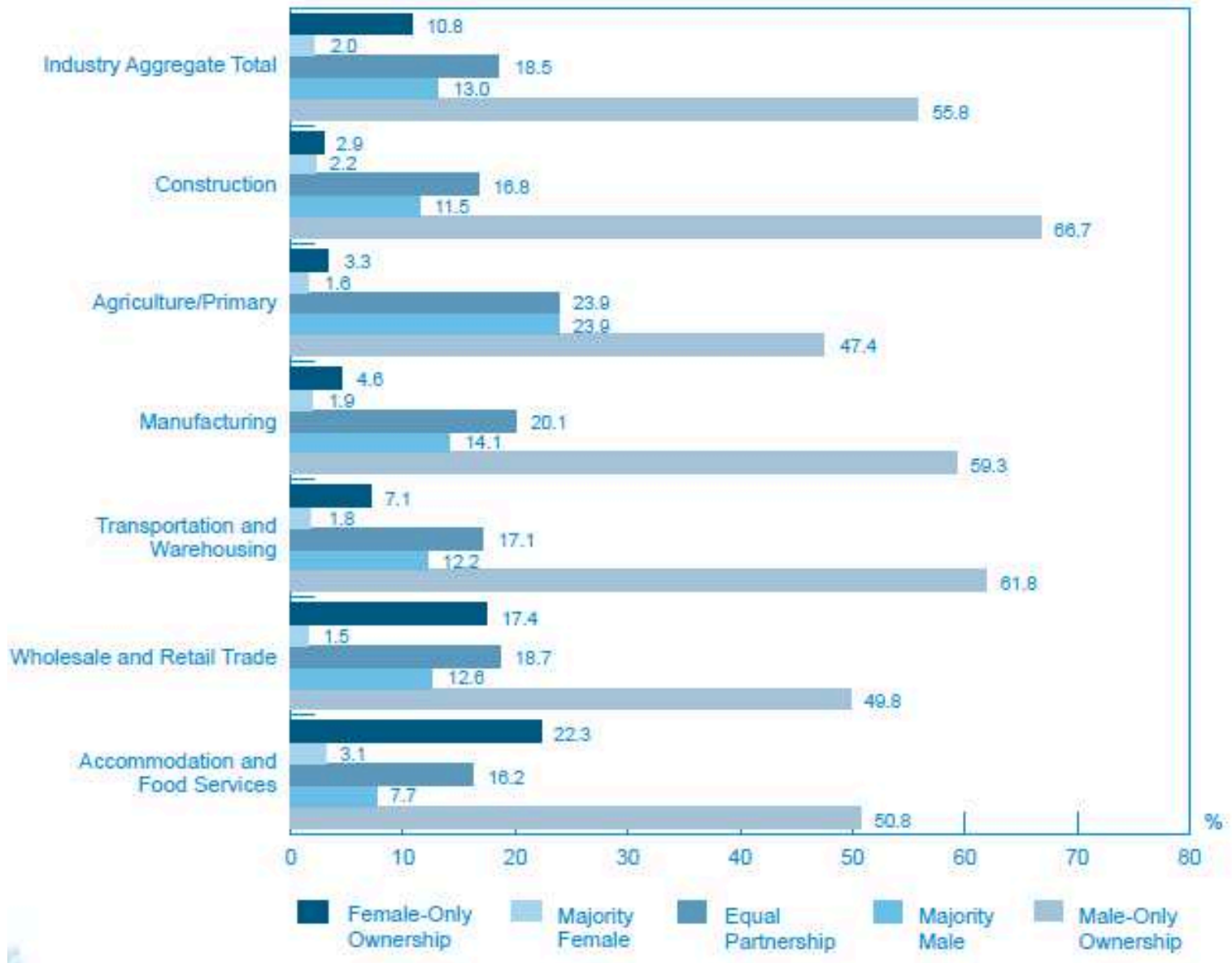

Source: Industry Canada, 2013 


\section{Age, Experience and Education of Small and Medium-sized Businesses' Owners:}

Between 2004 and 2011 the percentage of SMEs whose owners are less than 30 years old decreased from $2.9 \%$ to $1.6 \%$, the percentage of SMEs whose owners are between 30 and 39 and years old decreased from $15.3 \%$ to $10.6 \%$ (Figure 11). The proportion of SMEs with owners aged between 40 - and 49 years also decreased from $35.1 \%$ to $28.2 \%$. The entrepreneurship in Canada is greying since the percentage of SME's whose owners are between 50 and 64 years old increased from $37 \%$ to $48.4 \%$ and SMEs whose owners aged over 65 increased from $9.6 \%$ to $11.3 \%$ (Industry Canada, 2013). In a survey conducted by TD Trust, results show that $15 \%$ of baby boomers already started a small business after retirement, and $39 \%$ of baby boomers are considering starting SMEs prior to their retirement (TD Economics, 2012). However, the existence of baby boomers is smaller than younger entrepreneurs in the knowledge-based sector such as research, innovation, communications, and technology sectors.

\section{Figure 11: SME Owners’'Age Distribution}

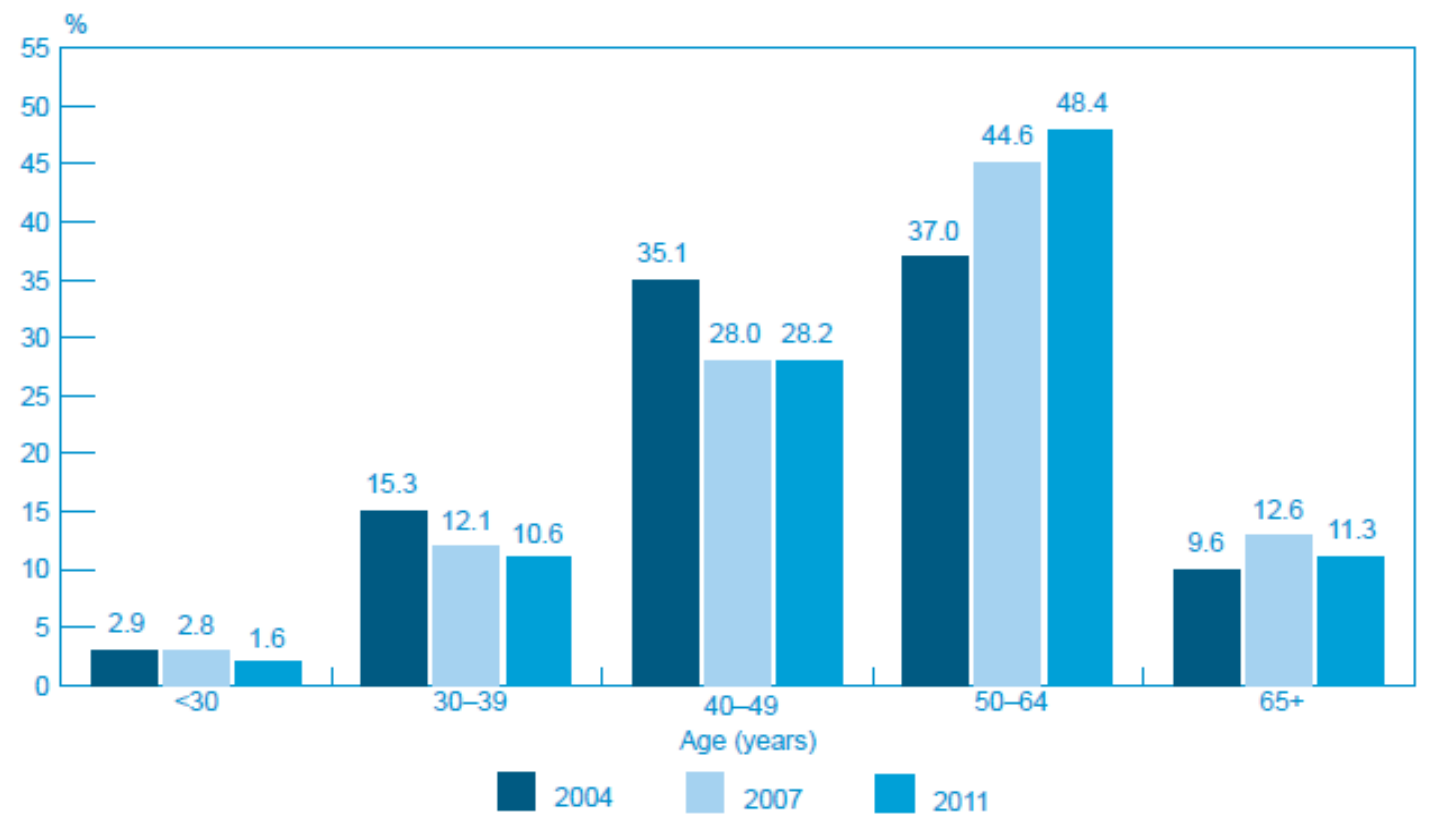

Source: Industry Canada, 2013 
Figure 12 shows that, between 2004 and 2011, the percentage of SMEs whose owners have less than 5 years of experience decreased from $12.4 \%$ to $\%$ of the total number of Canadian SMEs. The same pattern applies to SMEs whose owners have 5 to 10 years of experience (decreased from 18.4 to $17.8 \%$ ) (Industry Canada, 2013). $75 \%$ of Canadian exporters have been in business for at least 6 years (TD Economics, 2012). However, the percentage of SMEs owned by entrepreneurs with more than 10 years of experience grew from $69.3 \%$ to $77.2 \%$ of all small and medium enterprises operating in Canada (Industry Canada, 2013). 50\% of female entrepreneurs owning SMEs have less than 10 years of experience (TD Economics, 2012).

Figure 12: Percentage of SMEs Owners based on the Entrepreneurs' Number of Years of Experience in 2004, 2007, and 2011

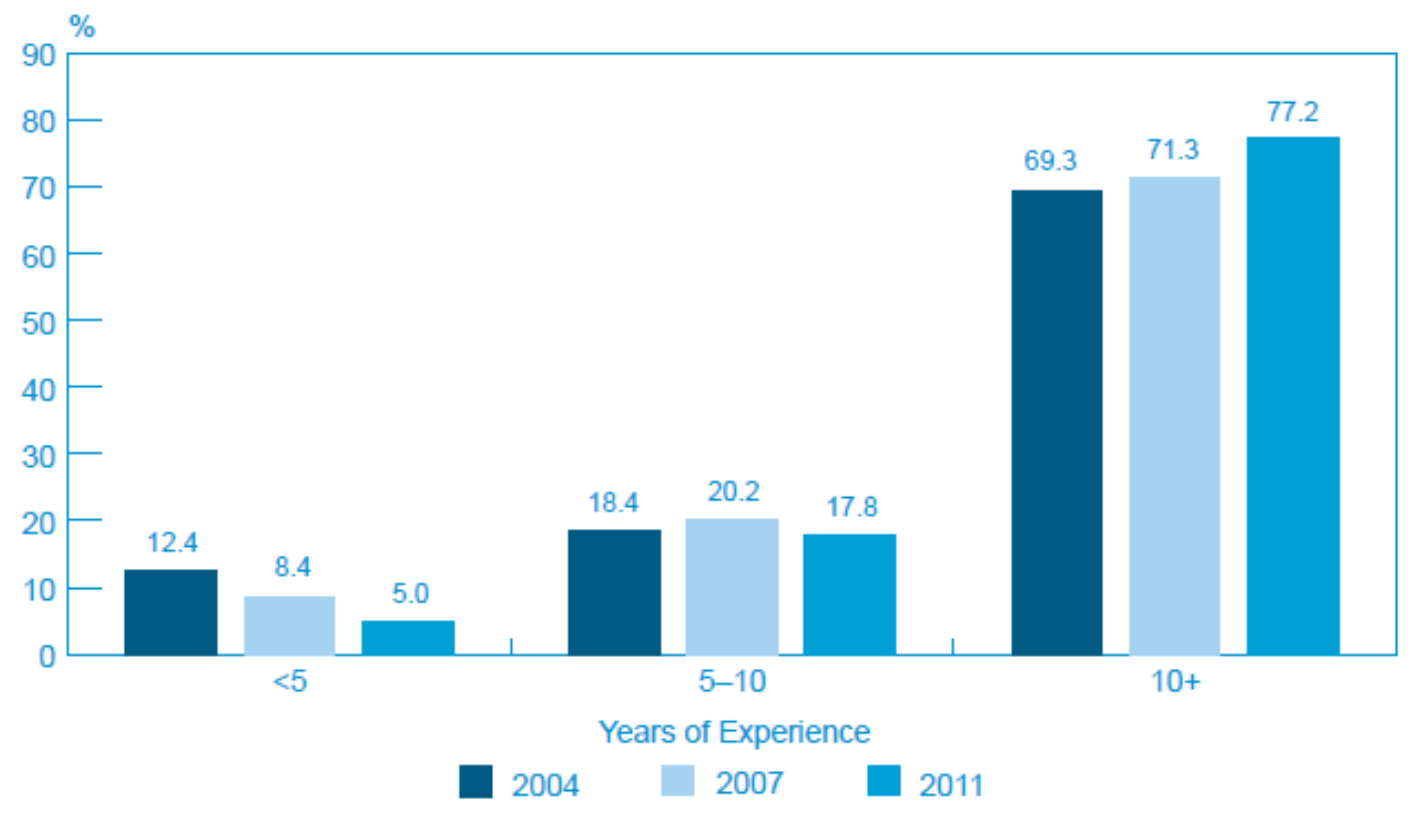

\section{Source: Industry Canada, 2013}

Figure 13 shows that the education characteristics of entrepreneurs operating in Canada has changes in recent years. The percentage of entrepreneurs with less than high school diploma, high school diploma, college CEGEp or trade school decreased from $9.6 \%$ to $5.1 \%, 23.9 \%$ to $14.6 \%$, and $32.2 \%$ to $20.3 \%$ respectively. On the other side, there is a significant increase in the 
proportion of SME owners with higher education. The percentage of SMEs whose owners have a Bachelor's degree increased from $21.7 \%$ to $39.4 \%$, and the percentage of SMEs owners with Master's degree or above grew from $12.7 \%$ to $20.7 \%$ (Industry Canada, 2013).

\section{Figure 13: SME Owners and Years of Education}

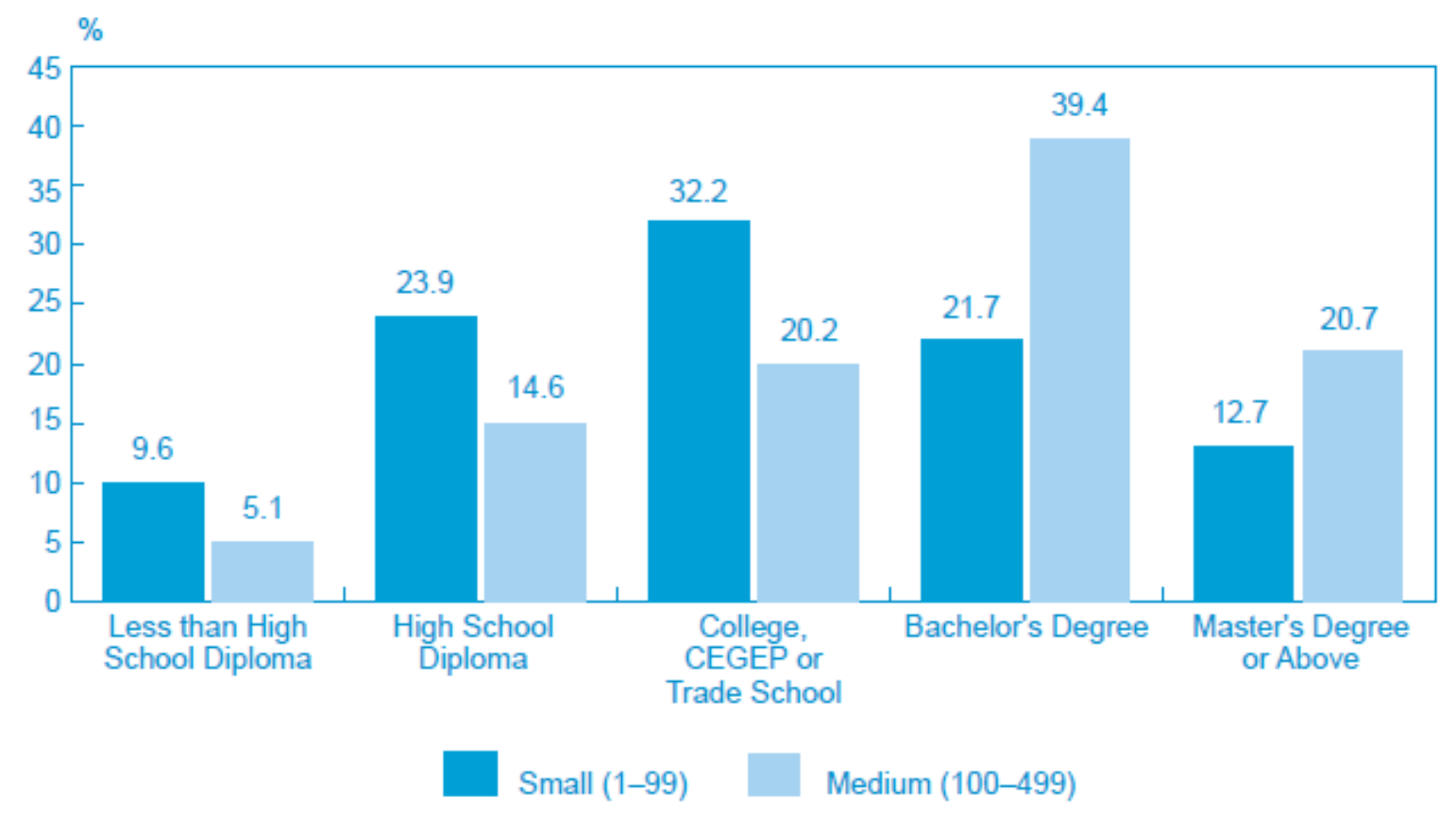

Source: Industry Canada, 2013 


\section{Appendix B: Interview questions Entrepreneur's background and characteristics}

-What kind of business do you own? Retail, technology, etc.?

-What inspired you to start your business? Are there any specific factors that influenced you to do so?

-Do you have a business partner?

-What is your educational background? Has it helped you deal with your business?

•How many hours do you spend working on your business per day?

• How do you balance between business and your personal life?

Internal and external resources supporting female entrepreneurship

\section{Education and mental support}

-Did you attend business and marketing classes? If yes, what did you learn from them?

-What resources, tools helped you start-up your business?

-Where did you access the resources that helped you to own your business?

-Do you have a mentor? Why or why not? If so, where did you meet them and how?

-How many community programs are there, that provide help for unemployed women? (that you know of)

- How did you find your idea for a start-up? 
-Are there any educational programs, colleges and universities that make funding accessible for females? (That you know of or have experience with)

-Do you feel that not enrolling in the business and management field prevents females from starting-up high technology businesses?

\section{Funding and legal support}

-Do you know of any institutions/organizations that offer funding for high technology female entrepreneurs? If so, have you had any experience with any?

-How easy or difficult is it to access funding to start a business?

-In your opinion, is it easy to communicate with policy makers to get funds?

-When you first started out, were the funds that you received enough to establish your business? Why or why not?

-Based on the literature review, women usually prefer to borrow money from relatives and friends to start up a business venture. Do you agree or disagree? Why or why not?

\section{General opinions about female versus male entrepreneurship/ start-up challenges}

-How do women entrepreneurs differ from men when it comes to starting up their businesses?

-Do you think male entrepreneurs are more successful than female entrepreneurs in the technology field, and why?

-Do you feel that male entrepreneurs have better chances to start their businesses, and why? 
-Based on the literature review, female face difficulties to promise to return the funds back to their loaners. Did you ever face this problem or know someone who has?

-What types of businesses do you think females aspire to own?

-Do you think women usually own smaller businesses than men do?

-What are the issues that you face as a female entrepreneur?

-Do you get time to do the household chores? If not, does someone help you? If yes, is there a typical time or day of the week you organize to do the chores?

-When you started your business, did you ever think about the challenges you might face?

-Do you feel the challenges in high technology business are different from traditional business?

-The literature review states that different challenges that are faced by women when they start-up high technology businesses are: lack of funds, risk to promise, an insufficient network, lack of business and management skills, lack of technological innovative business ideas, overcoming bad business experiences, lack of motivation, and family obligations. Based on this list, do you see any challenges that you have face? Are there any other challenges that have not been mentioned in this list? If so, are you familiar with any?

-How do you react to each challenge that you face and what helps you overcome it?

-What advice would you give to a future high technology female entrepreneur? 


\section{Appendix C: Frequency of problems and challenges mentioned in the interviews}

\begin{tabular}{|l|c|c|}
\hline Challenge & Frequency & Percentage \\
\hline Lack of technologically innovative business ideas & 26 & $22 \%$ \\
\hline Insufficient business network & 25 & $21 \%$ \\
\hline Lack of business and management skills & 20 & $17 \%$ \\
\hline Family obligation & 17 & $14 \%$ \\
\hline Lack of financial support & 16 & $8 \%$ \\
\hline Lack of motivation & 9 & $2 \%$ \\
\hline Risk to promise & 3 & $2 \%$ \\
\hline Overcoming previous bad experiences & 2 & $100 \%$ \\
\hline Total & 118 & \\
\hline
\end{tabular}

Figure 14. Illustration of frequencies of mentioned problems and challenges

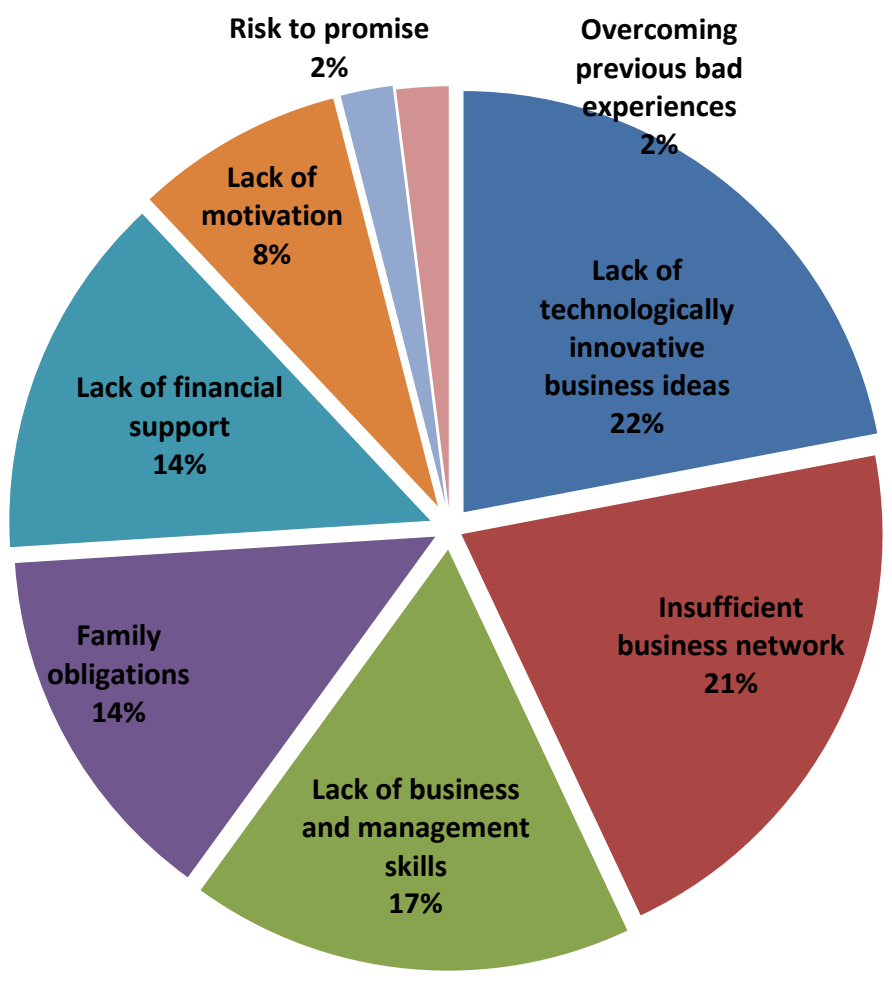




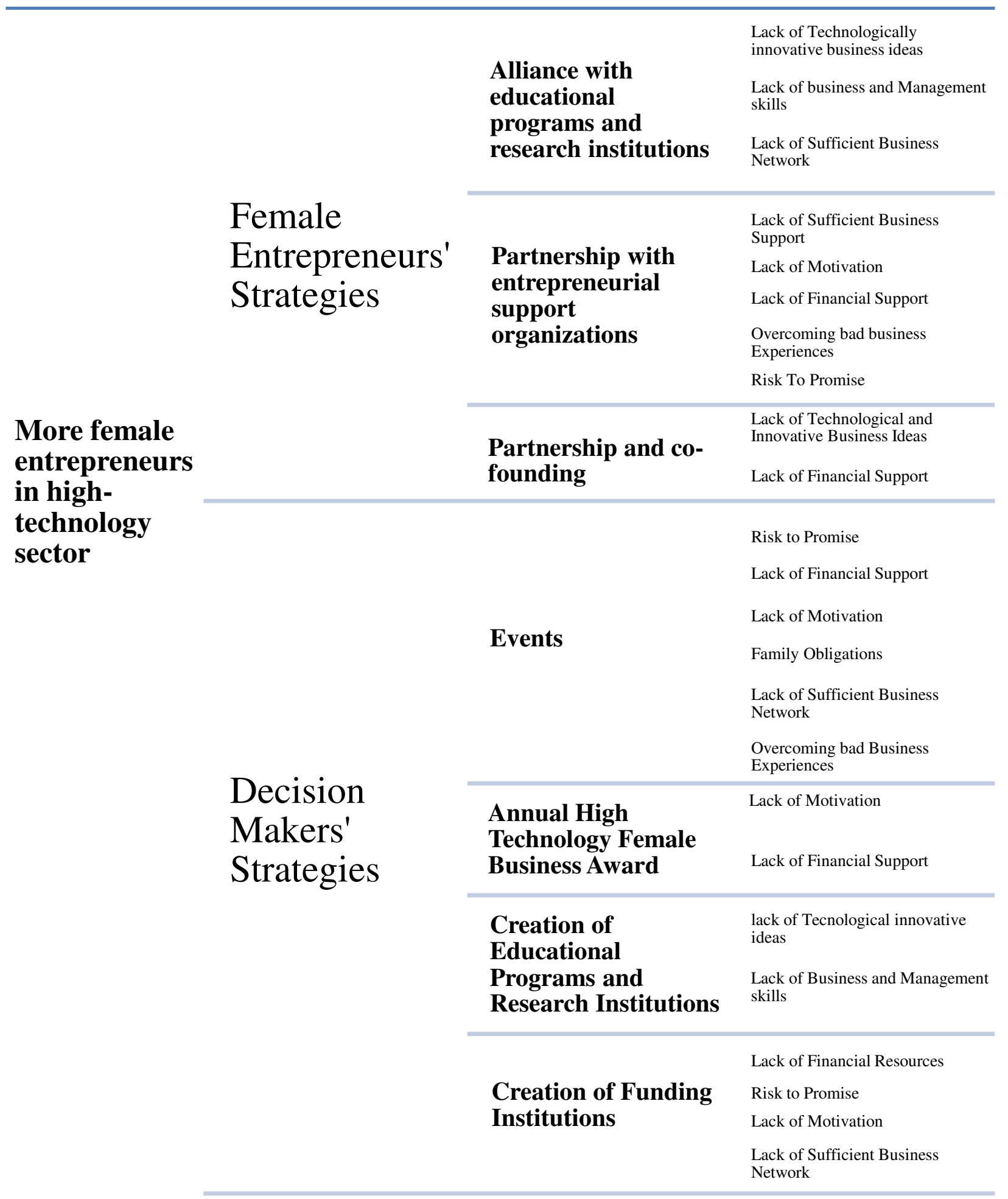

